\title{
المقدمـــة
}

الحمد لله رب العالمين، والصلاة والسلام على سيدنا محمد النبي الأمي الأمين،

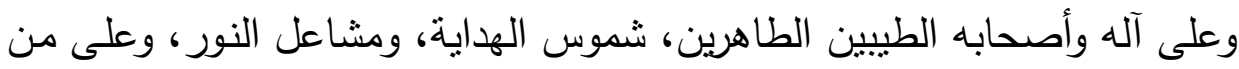
اتبعهم وسار على نهجهم إلى يوم الدين.

\section{وبعـد ....}

فما أجمل الثعر حين يكون أداة لتجسيد المناقب، وتصوير المآثر؛ لأنه حينئذ - يكون وسيلة لنشر الفضيلة، وسبيلاً لإسعاد البشرية، بإرشادها إلى القدوة.

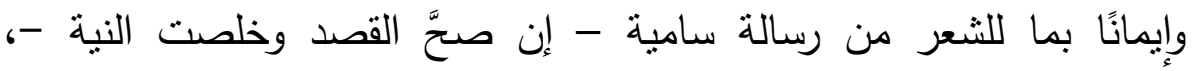

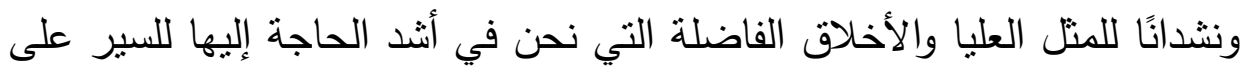

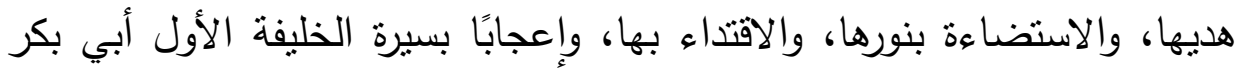

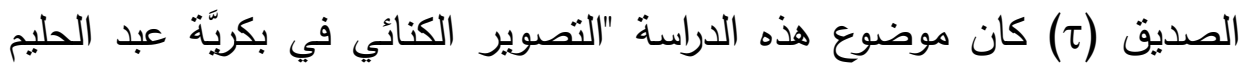

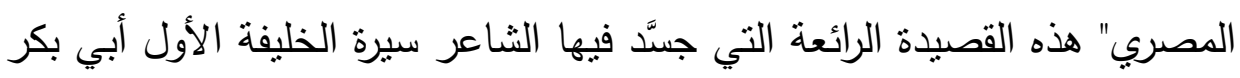

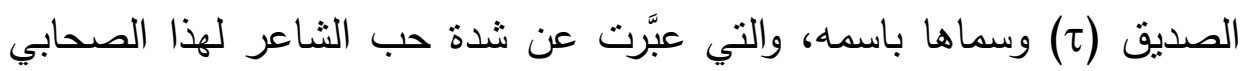

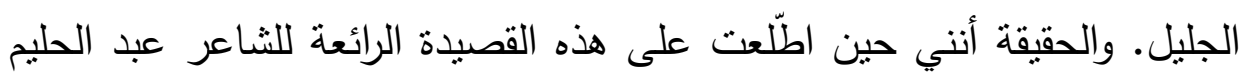

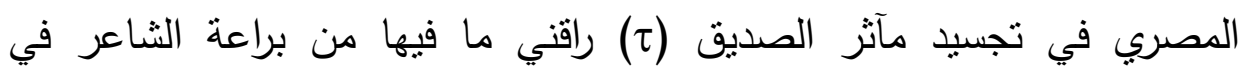

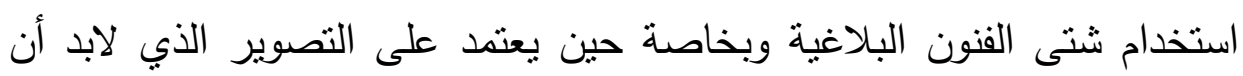

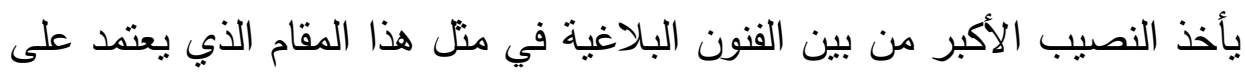

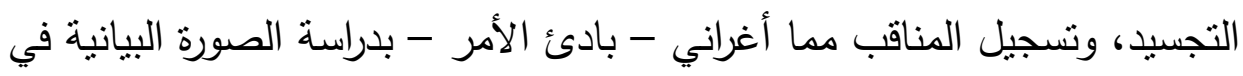

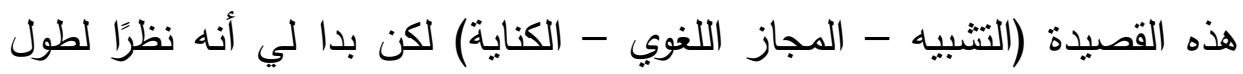

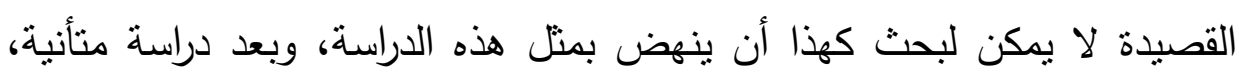

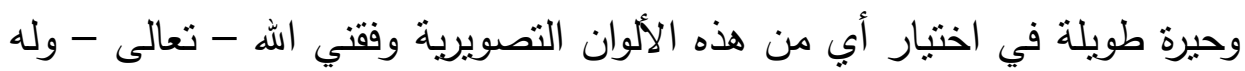

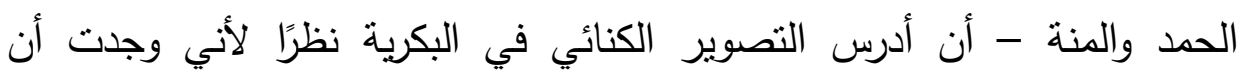


الثناعر لا تقف غايته في تجسيد مآثر الصديق (ح) عند مجرد الإخبار بها وتعدادها. فكلها مواقق مشهورة ومعروفة وظاهرة، فمَنَ الذي تخفى عليه مواقق آنَ

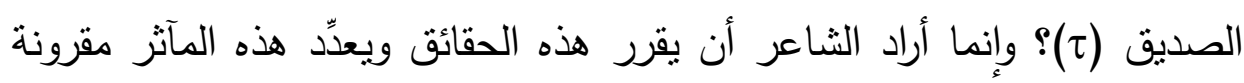

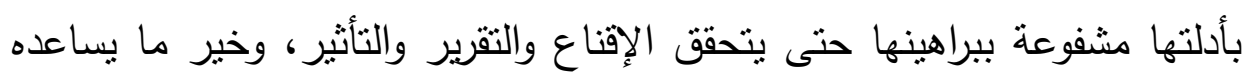

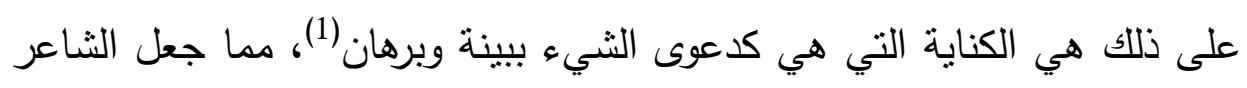

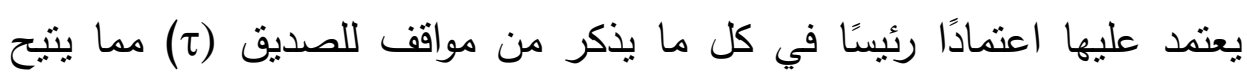

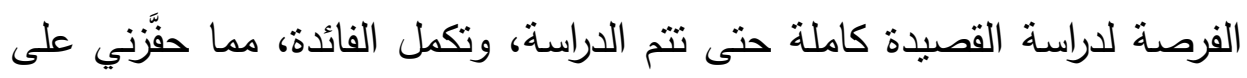

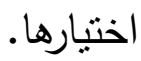

وقد اقتضنتي طبيعة البحث أن أسير في استقصاء شواهد الكناية حسب المواقف التي ذكرها الثناعر في القصيدة ذاكرًا موطن الكناية في البيت، وكيفية

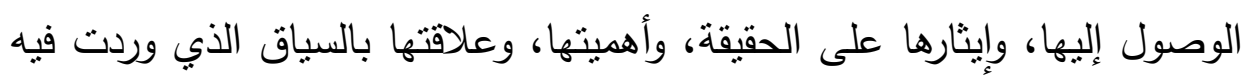

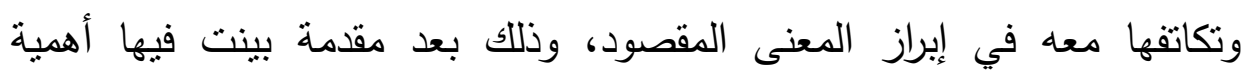

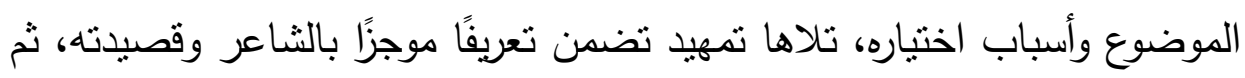

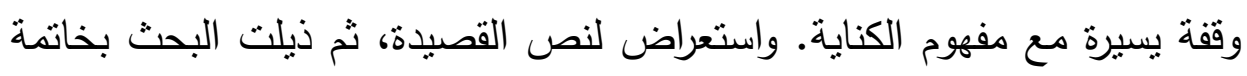

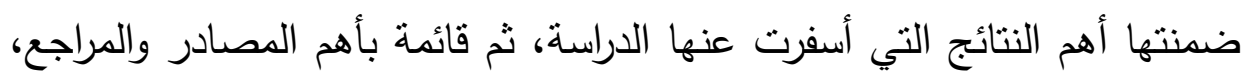
ثم فهرس للموضوعات. وتجدر الإثشارة إلى أنه لم يكن من المناسب تقسيم البحث حسب الأقسام

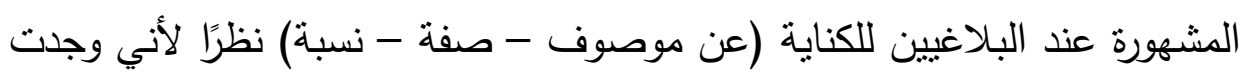
أن بعض هذه الأقسام قد اختفت في القصيدة - كما سيتضح من خلال الدراسة -

(1) ينظر : شروح النذيص (275/4)، المطبعة الكبرى الأمبرية، بولاق، ط1، 1323ه. 
إن شاء الله - تعالى - وبعضها لم يأت إلا من خلال نزر يسير من الشواهد،

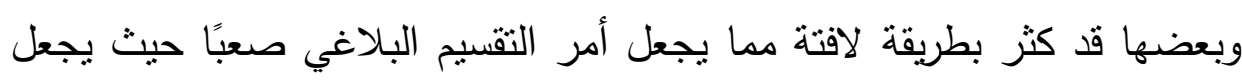
تفاونًا بين الأقسام، كما أنني وجدت أن التقسيم حسب المواقف أفضل حتى ينم ربط الكناية بسياقها، وما يليها من كنايات دون تكرير أو إعادة.

\title{
والله من وراء القصد وهو حسبي ونعم الوكيل
}

\author{
الباحث
}

دكتور/ ياسر عبد الحمبد عرقوب

مدرس في قسم البلاغة والنقد بالكلية 


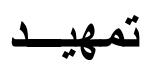

أولاً: التعريف بالثـاعر وقصيدته:

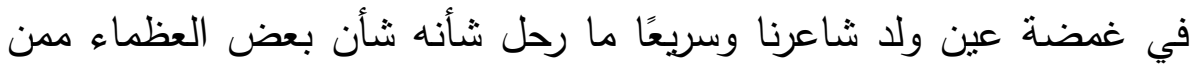

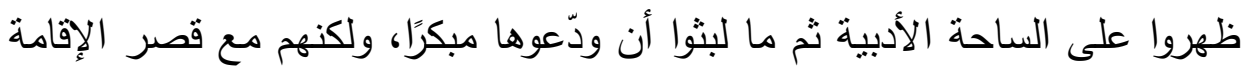

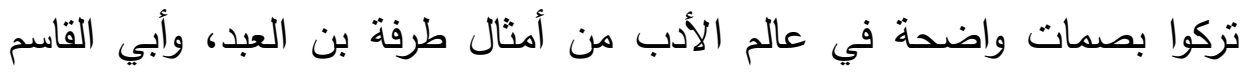

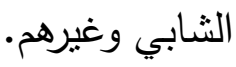
فقي نهاية القرن التاسع عشر، وبالتحديد في عام 1887م ولد الثاعر عبد

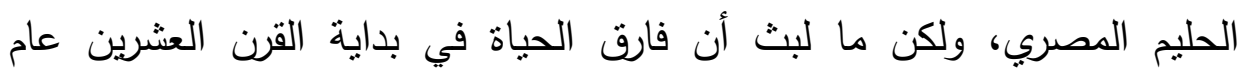
1922م. وهو في ريعان الثباب.

وهذه الفترة بالتحديد كانت فنرة ازدهار للأدب، حيث شهدت ميلاد علماء أفذاذ

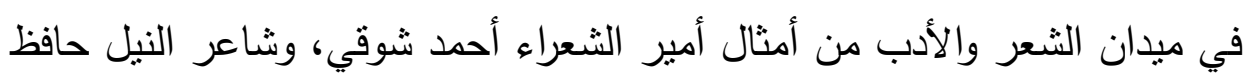

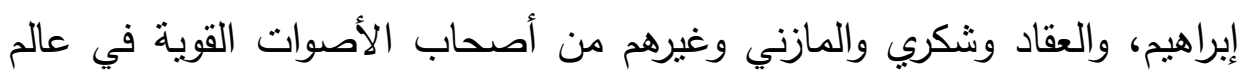

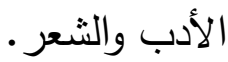

وقد انتهج المصري نهجهم في الإقبال على الثُعر القديم وبعثه من جديد،

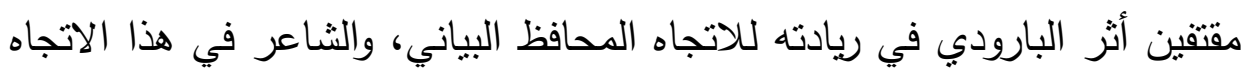

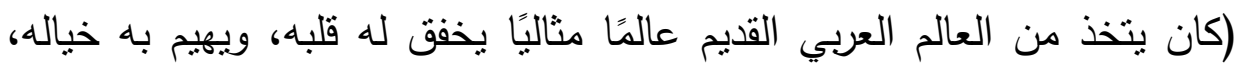

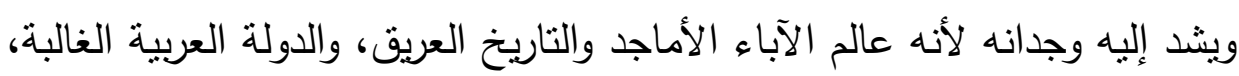

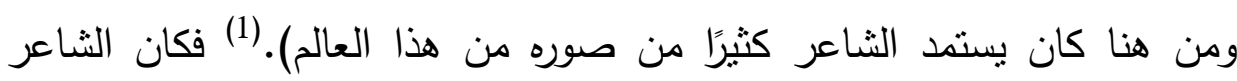

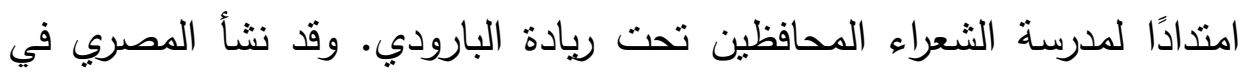
عصر يموج بالرواد - كما سبق - مما يوحي بصعوبة الثهرة، وإثبات الذات، لكنه

(1) تطور الأدب الحيث في مصر ، د/ أحمد هيكل صـ62، دار نهضة دصر للطباعة والنشر. 
على الرغم من صغر سنه قد استطاع أن يتبوأ مكانة عالية في سماء الشعر آنذاك، وأن يقف جنبًا إلى جنب مع هؤلاء الرواد، ويكون له دوره في إحياء الشعر

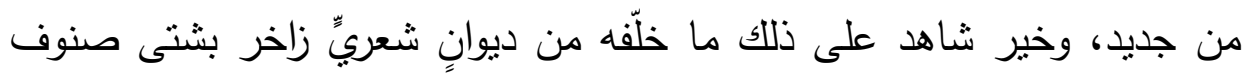
الألوان الثعرية يدل على موهبة شعرية فذة، وقدم في الثعر راسخة. وكانت وفاته فاجعة كبيرة جسدها حافظ إبراهيم قائلاً في رثائه:

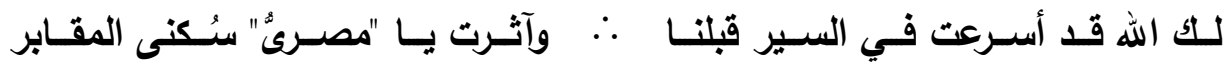

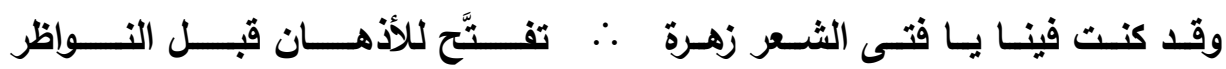

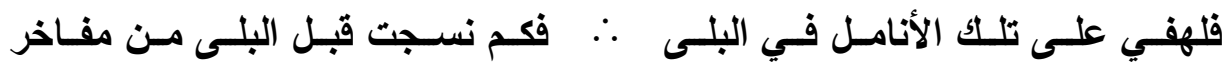

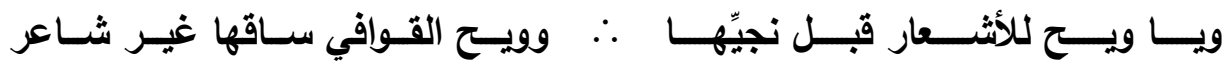

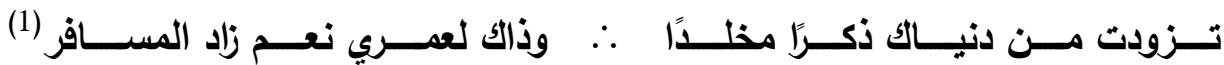

أما عن البكرية فهي قصيدة رائعة ومطولة خالدة تقترب من المائتي بيت صاغها الثاعر تعبيرًا عن حبه لسيدنا أبي بكر الصديق (ح) وتجسيد مآثره، وهي مسك ختام الجزء الثاني في ديوانه، وقد ترك فيها الثاعر نفسه على سجيتها لتتطلق بما تكنه من حب متأجج للصديق (ح) وسيرته معددة فضائله ومواقفه فألهمها هذا الحب كل قول جميل، ومعنى جليل، وقد اعترف هو بذلك في مطلعها. كما أنها تعد شمعة على الطريق الحالك الذي تحياه أمتتا في هذه الأيام

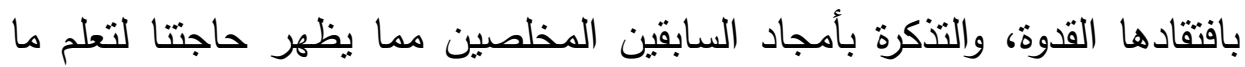
فيها، والسير على نهجها حتى ننهض من كبوتتا ونعود إلى سيرتتا الأولى مهتدين

ديوان حافظ إبراهيم، ضبط وتصحيح وشرح وترتيب: أحمد أمين - أحمد الزين - إبراهيم الإبياري (202/2)، دار العودة، بيروت، لبنان. 
راثندين، فقد عرض فيها الثناعر لجوانب مشرقة، ومواقف عظيمة في حياة

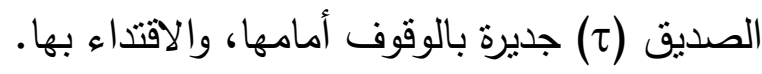

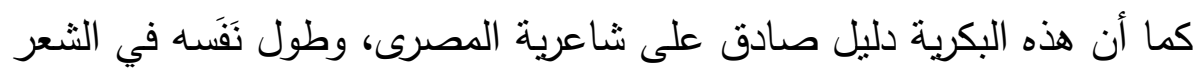

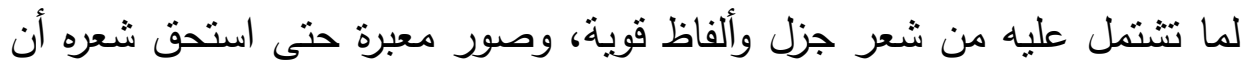

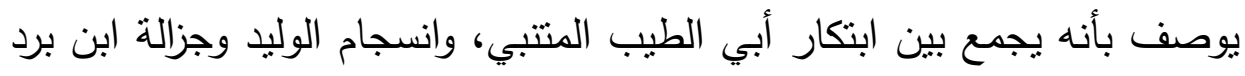

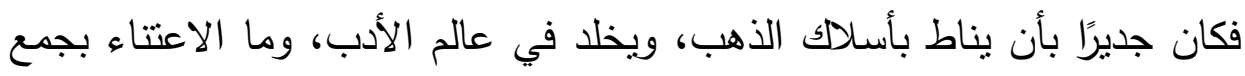

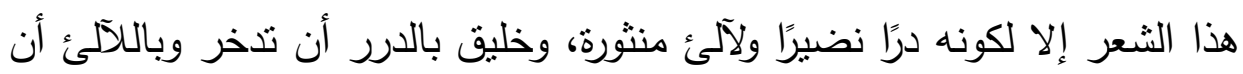

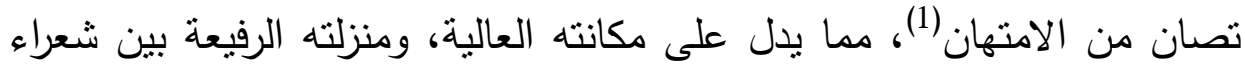

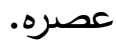

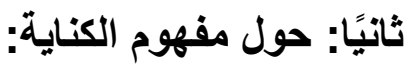

جاء في لسان العرب: الكناية أن تتكلم بشيء وتريد غيره، وكنى عن الأمر بغيره يكنى كناية يعني إذا تكلم بغيره مما بستخل عليه نحو الرفث والغائط ونحوه.

أما في اصطلاح البلاغيين: "فهي لفظ أطلق وأريد به لازم معناه مع جواز إرادة

(3). معناه حينئن

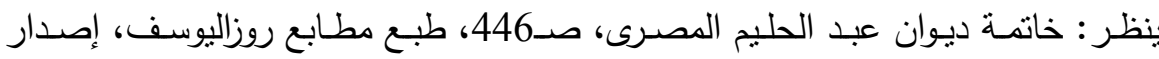

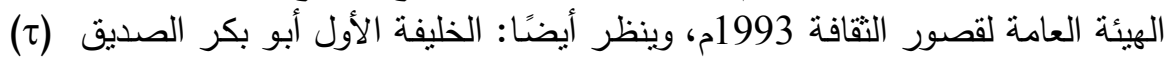

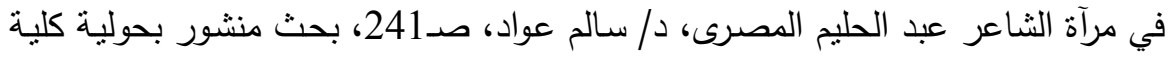

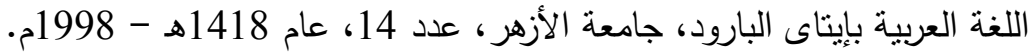

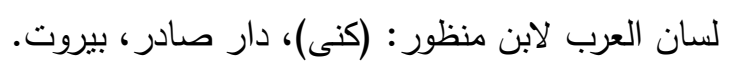

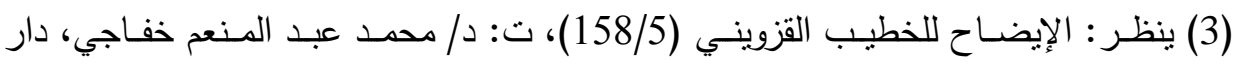

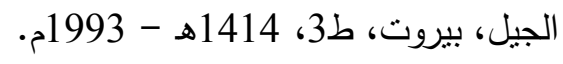


وقد ذكر الثيخ عبد القاهر معنى الكناية، واستوفاه بالثرح فقال: "والمراد

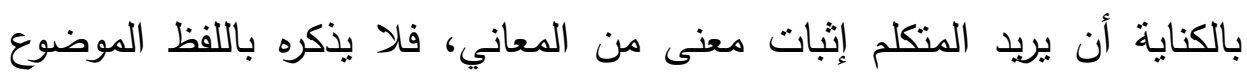

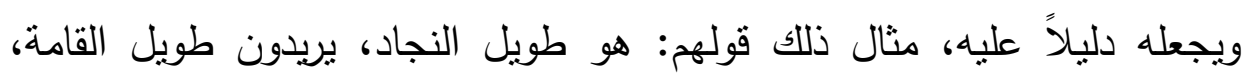
وكثير الرماد، يعنون كثير القرى، وفي المرأة نؤوم الضحى، والمراد أنها منرفة مخدومة، لها من يكفيها أمرها فقد أرادوا في هذا كله كما ترى معنى، ثم لم يذكروه بلفظه الخاص به، ولكنهم توصلوا إليه بذكر معنى آخر من شأنه أن يردفه في الوجود، وأن يكون إذا كان.

أفلا ترى أن القامة إذا طالت طال النجاد، وإذا كثز القرى كثر رماد القدر، وإذا كانت المرأة منرفة لها من يكفيها أمرها، ردف ذللك أن تتام إلى الضحى". (1) ولابد في كل كناية من علاقة وقربنة كما هو الحال في المجاز إلا أن قرينة الكناية لا تمنع من إرادة المعنى الأصلي بخلاف قرينة المجاز فهي مانعة من إرادة

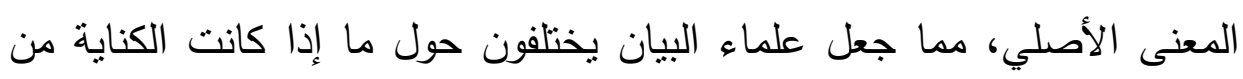
باب الحقيقة أو من باب المجاز ؟

(1) دلائل الإعجاز : ت شاكر صد(66)، مكتبة الخانجي، القاهرة، مطبعة المدني. 
فمنهم من عزاها إلى باب المجاز وأنها نوع من أنواعه، بحجه أن اللفظ فيها

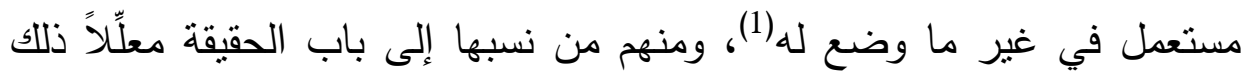

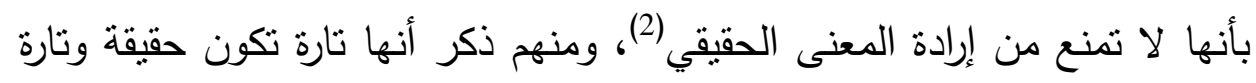

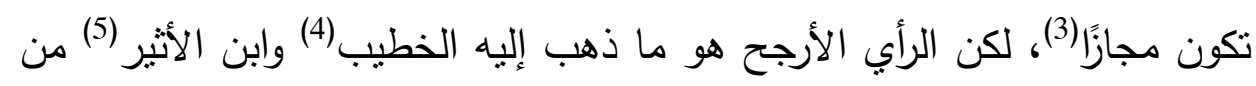

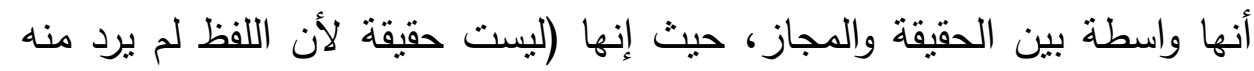

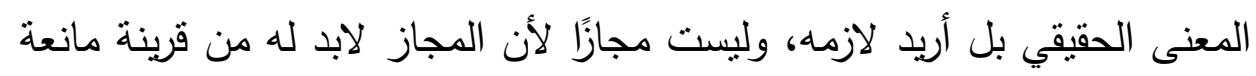

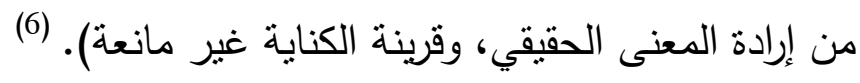
وقد قسَّ البلاغيون الكناية باعتبار المعنى المكني عنه إلى ثلاثة أقسام: (كناية إنهاية عن موصوف - كناية عن صفة - كناية عن نسبه).

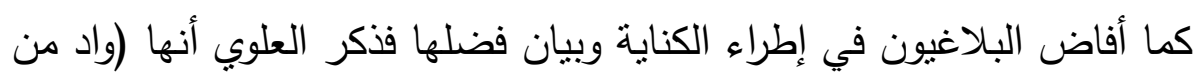

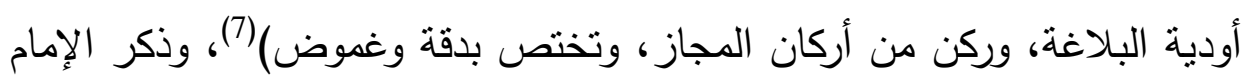

ينظر : الطراز : المتضمن لأسرار البلاغة وعلوم حقائق الإعجاز للعلوي (364/1)، مطبعة

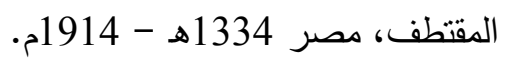

ينظر : نهاية الإيجاز في دراية الإعجاز للارازي صداف272، ت / بكري شيخ أمين، دار العلم

$$
\text { للملايين، ط1، } 1985 .
$$

هذا الرأي للشيخ السبكي ضمن شروح التلخيص (243/4).

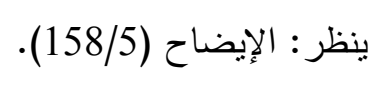

(5نظر : المثل السائر لابن الأثير صـ(157)، 378)، 378، تصحيح وتنقيح / محمد الصباغ،

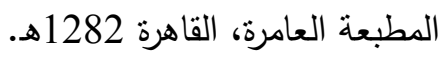

(6) البيان في ضوء أساليب القرآن، د/ عبد الفتاح لاثثين صـ(266)، دار الفكر العربي، ط2،

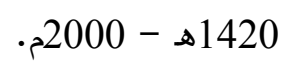

$$
\text { (7) الطراز العلوي، صـ(1720). }
$$


عبد القاهر أنها (فن من القول دقيق المسلك، لطيف المأخذ ...).(1) ويكفي أنها

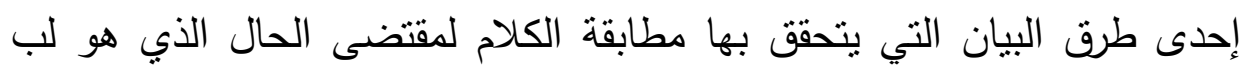

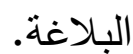

\section{وترجع بلاغة الكناية إلى سبيبن:}

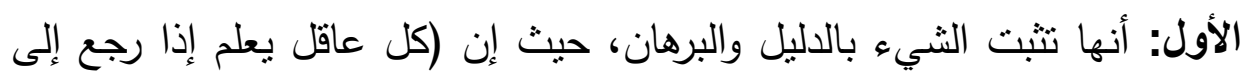

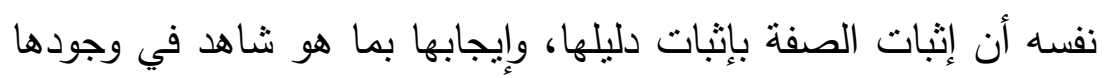

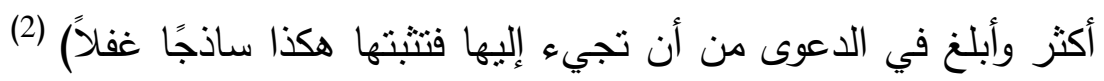

وفي هذا تأكيد للمعنى.

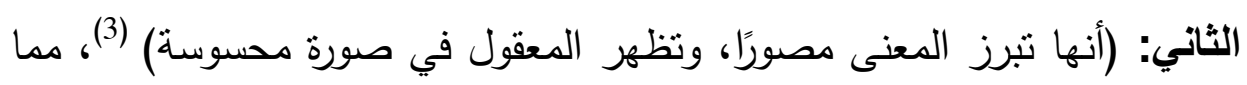

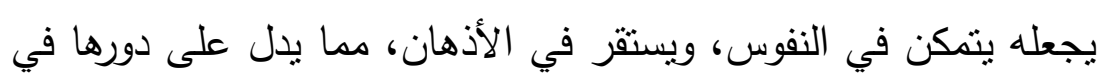
أداء المعنى، وإبرازه.

$$
\begin{aligned}
& \text { (1) دلائل الإعجاز ، صـ(306). } \\
& \text { (2) السابق، صد(72). }
\end{aligned}
$$

(3) ينظر : أفنان البيان، د/ الثحات أبو ستيت، صـ(269)، مطبعة التركي، طنطا 1417هـ 1996 


\section{نصنُ القصيدة}

أبو بكر الصديق نمئق

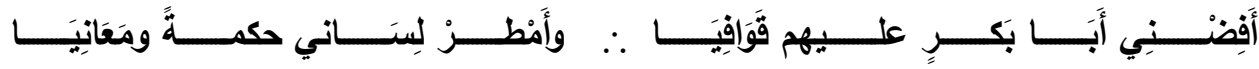

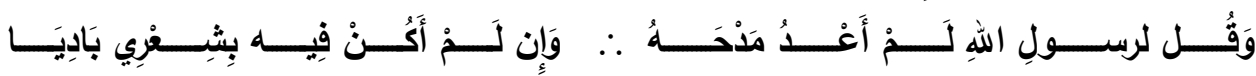

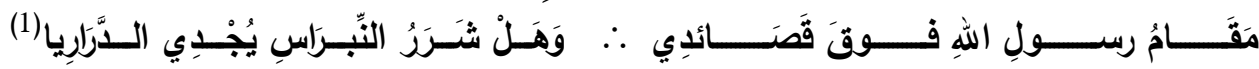

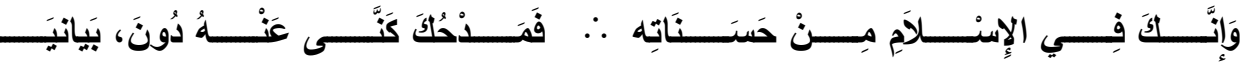

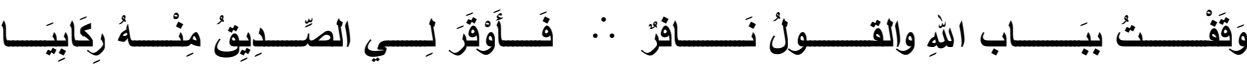

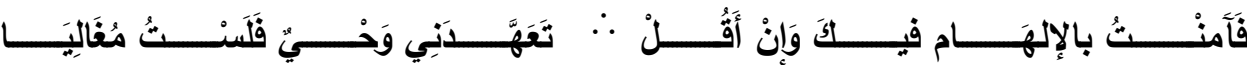

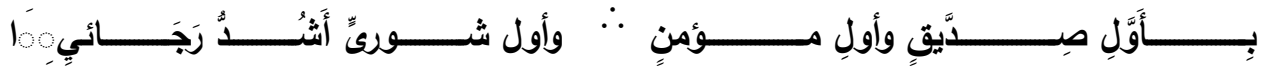

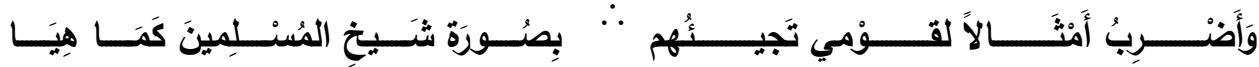

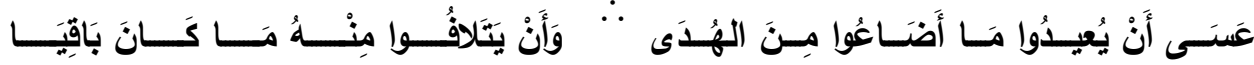

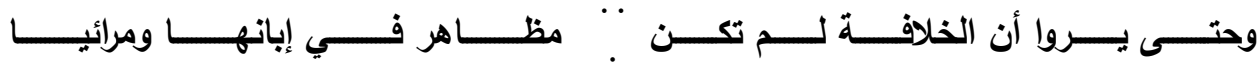

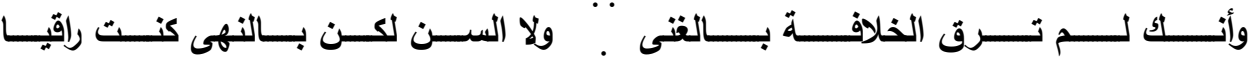

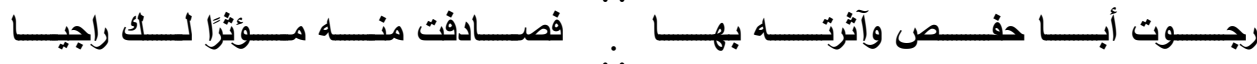

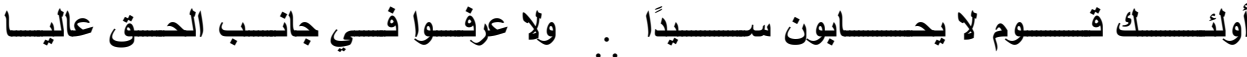

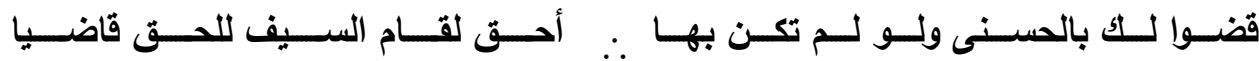

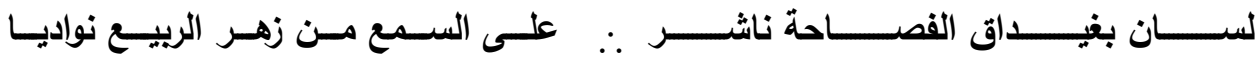

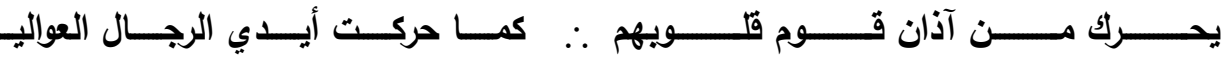

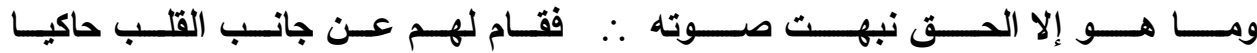

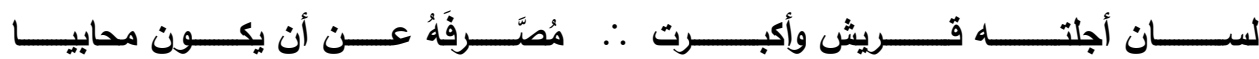

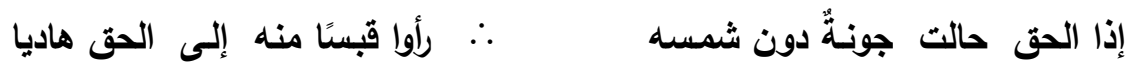




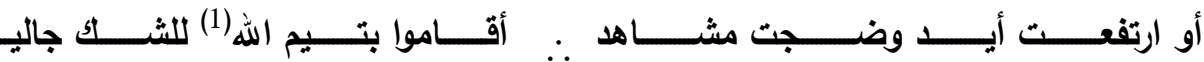

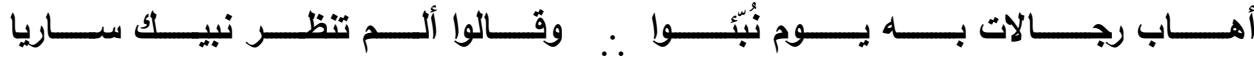

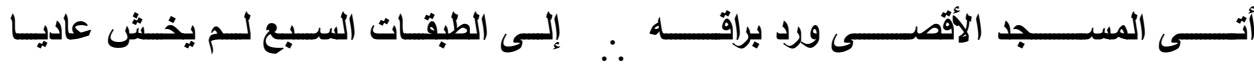

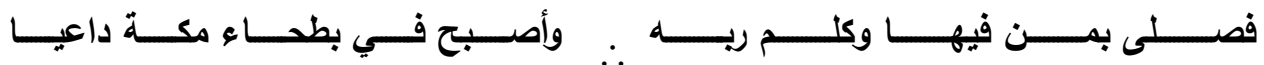

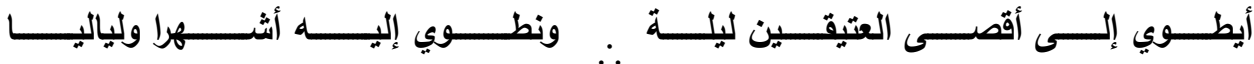

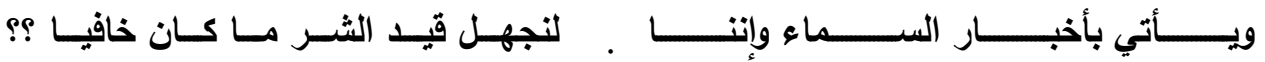

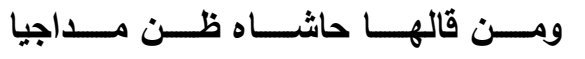

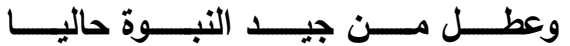

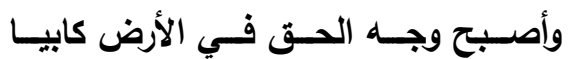

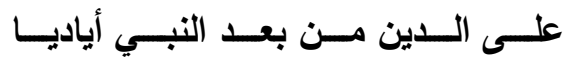

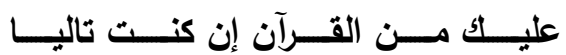

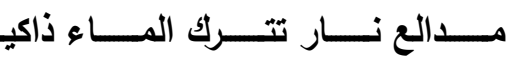

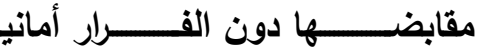

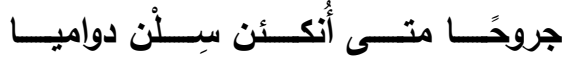

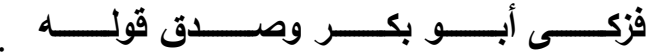

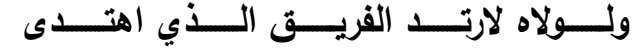

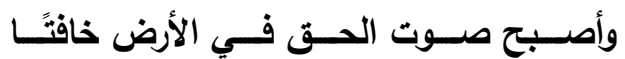

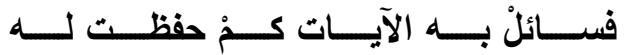

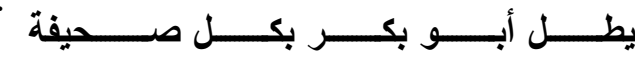

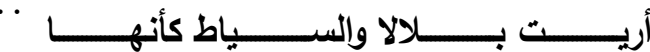

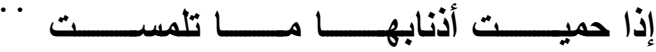

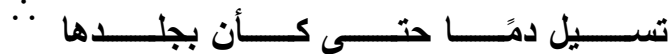

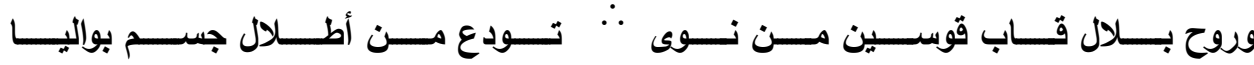

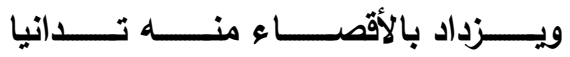

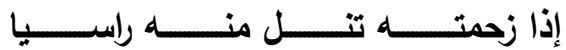

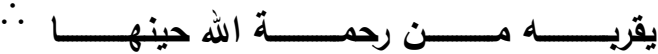

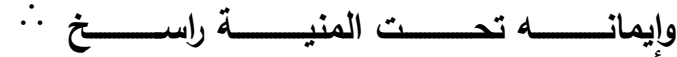

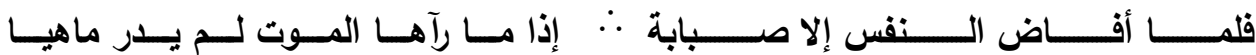

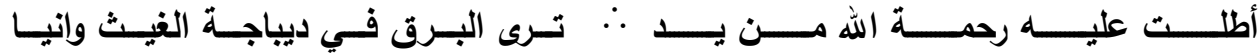

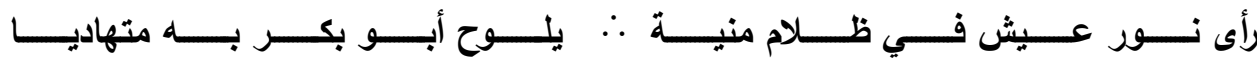

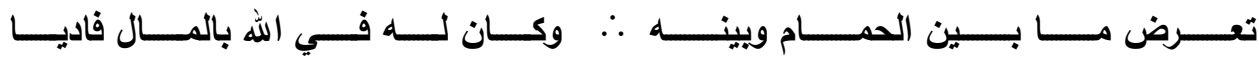
كريم يرى ما في يد الناس فـان

(1) قبيلة أبي بكر وتيم في الأصل اسم الجد السادس له الذي يلتقي فيه مع رسول اله (م). 


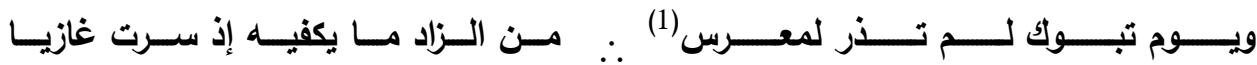

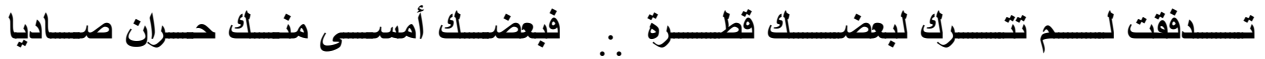

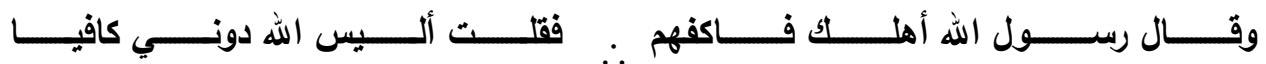

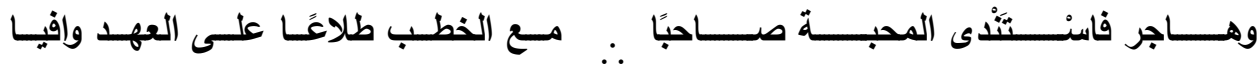

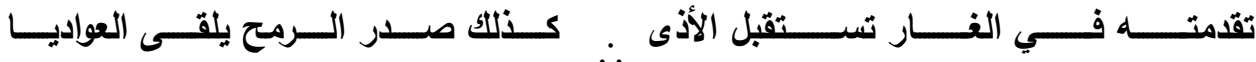

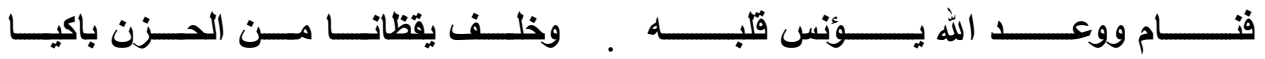

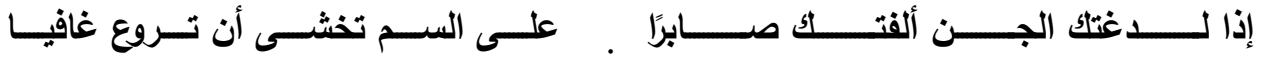

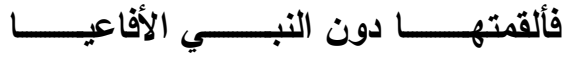

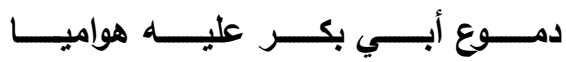

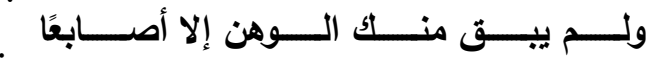

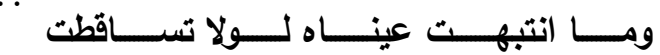

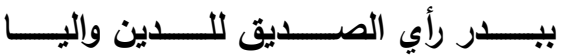
سـنى لـــ يـزل فـي مـوطن السـر فاثـيا

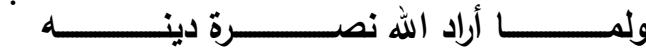

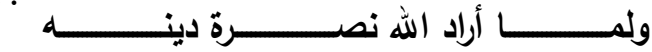

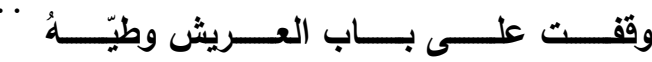

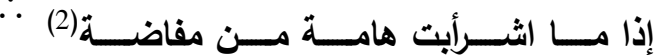

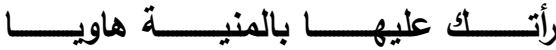

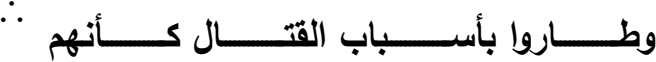

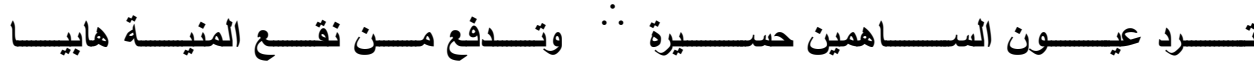

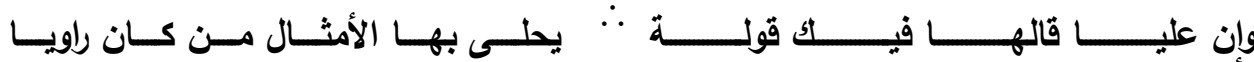

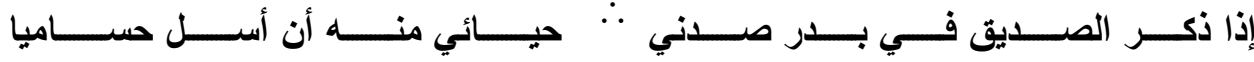

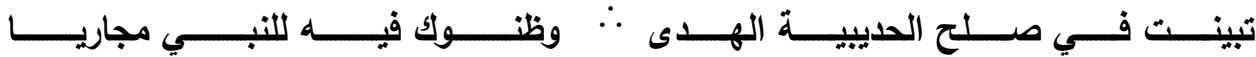

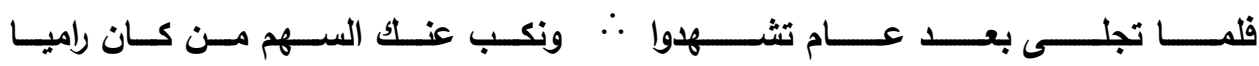

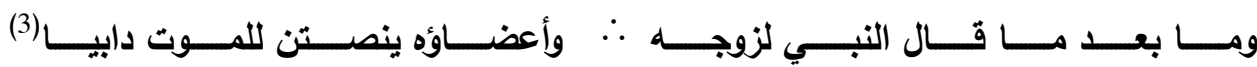
مريـه يقم بالمسلميـن مصليا

(1) يقال أعرس القوم وعرسوا أبي نزلوا في آخر الليل للاستراحة. (2) المفاضة: من الدروع الواسعة. (3) الدبي: المشي الرويد. يقال (دبيت) واسم الفاعل على القياس (دابي) أب ماشٍ رويدا. 


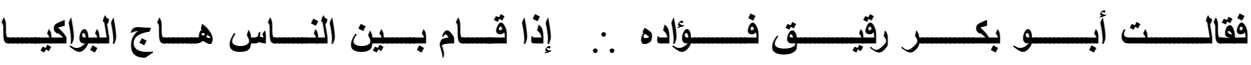

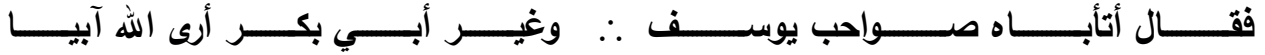

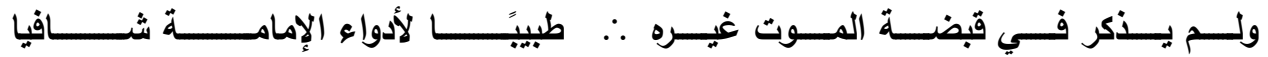

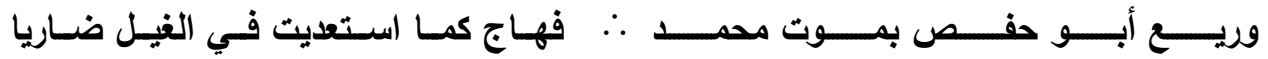

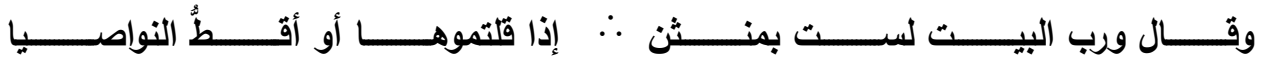

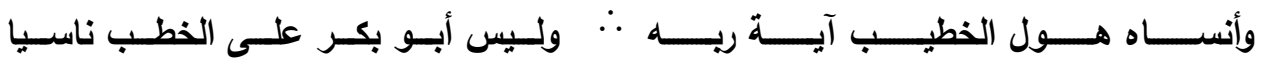

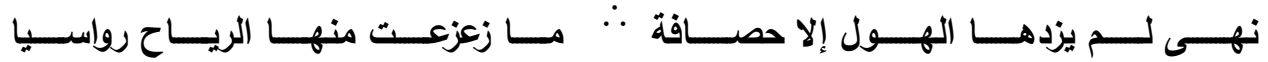

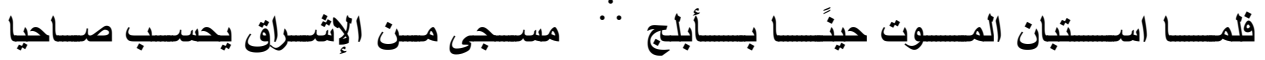

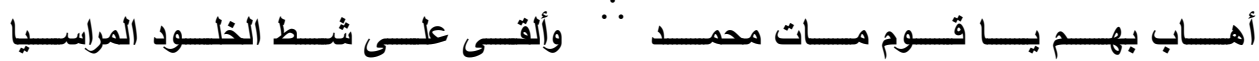

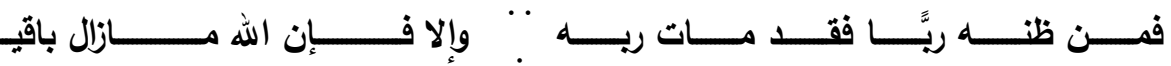

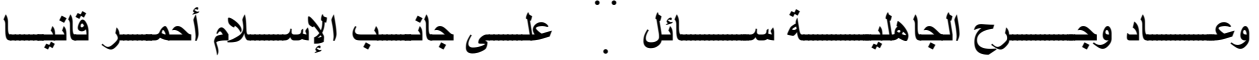

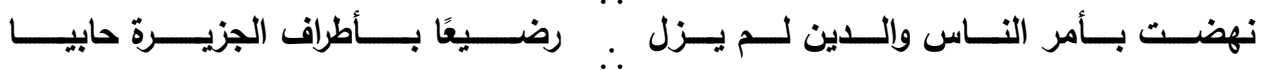

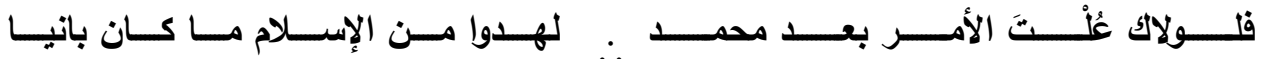

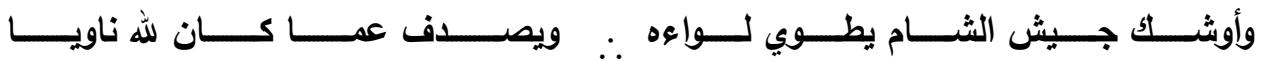

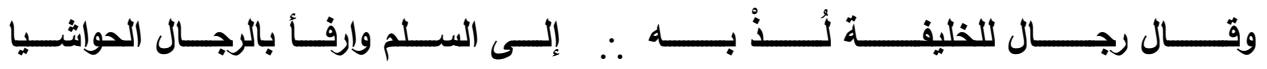

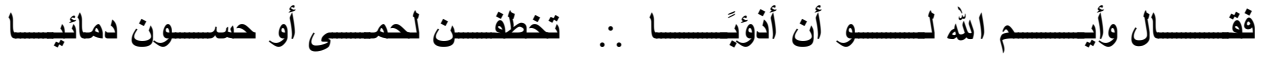

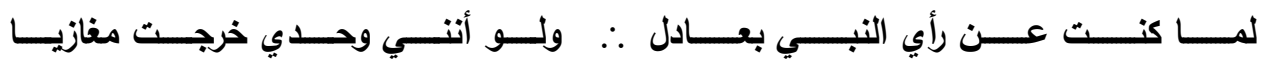

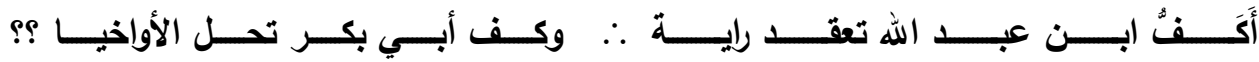

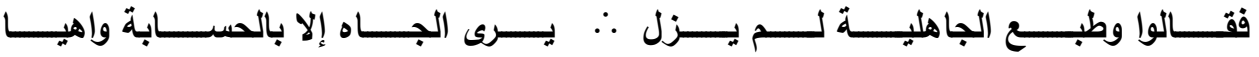

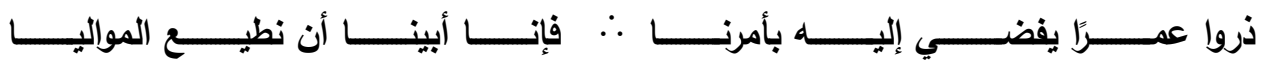

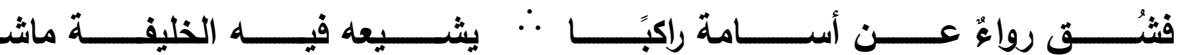

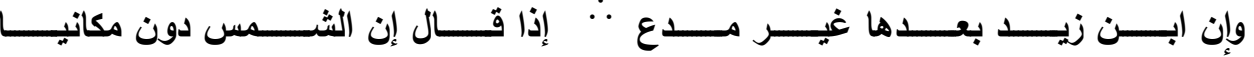

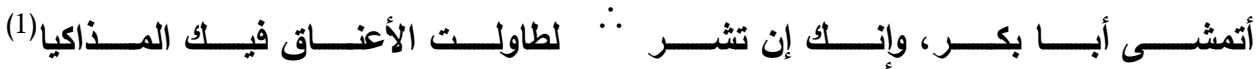




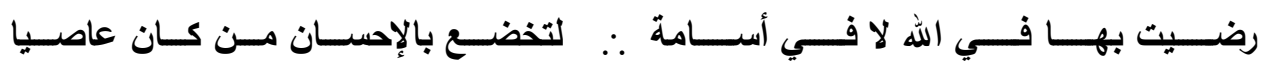

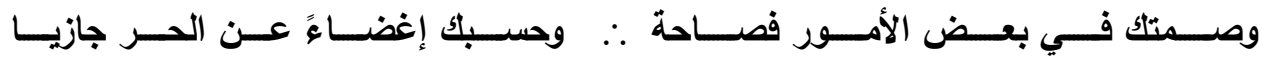

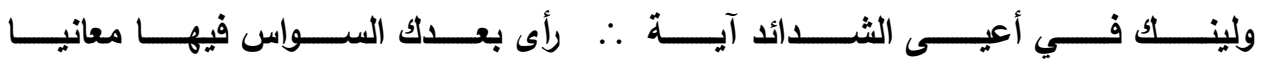

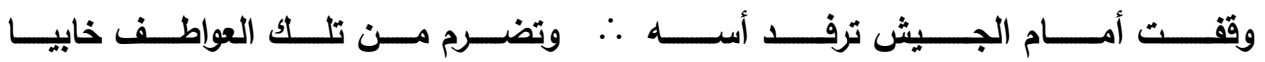

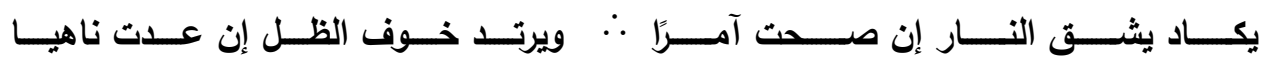

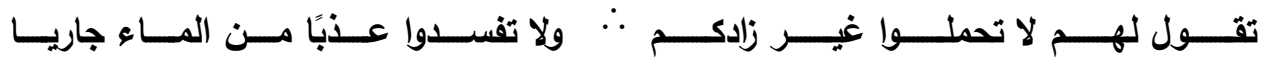

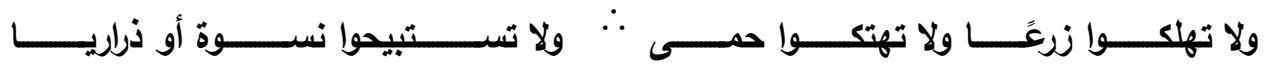

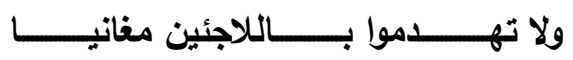

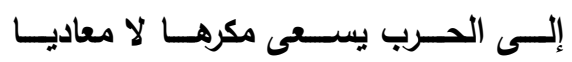

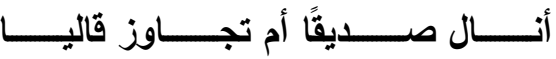

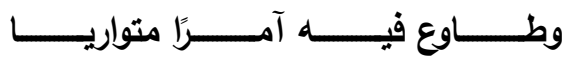

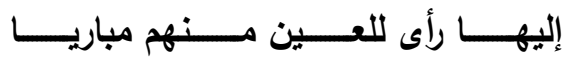

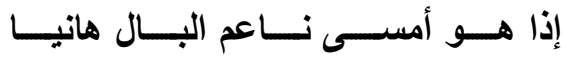

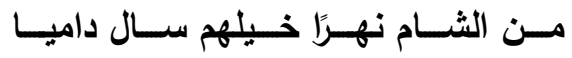

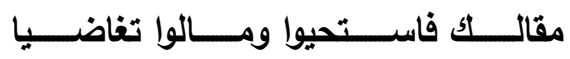

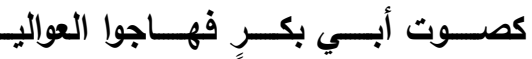

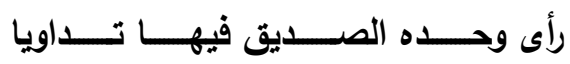
بمسن ظـل فـــي جـوف المدينـة ثناويــا ولا كنت بالأخطار فيسه مباليـا

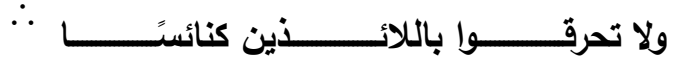

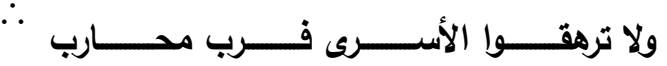

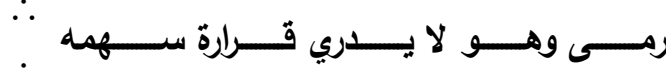

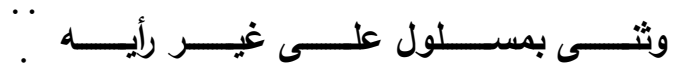

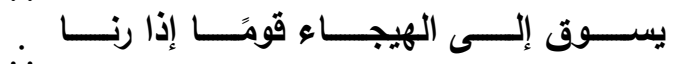

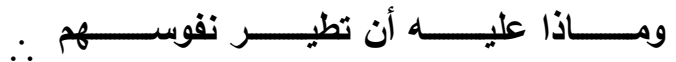

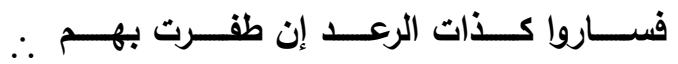

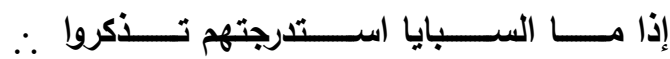

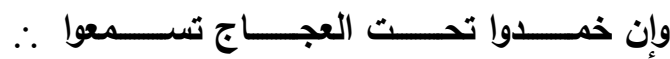

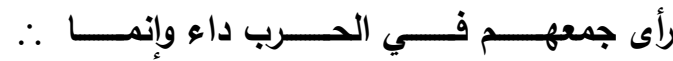

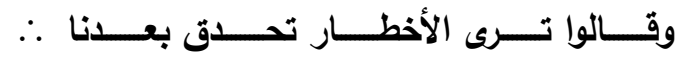
فما كنت في أري النبي معارضـاً

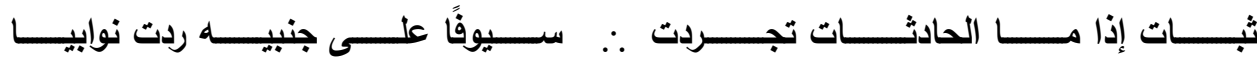

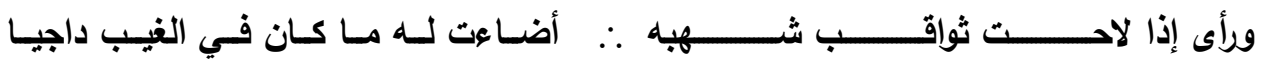

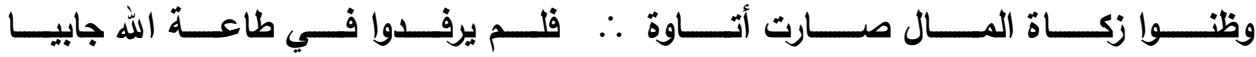

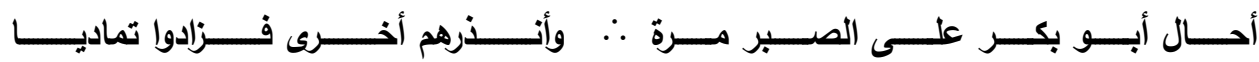

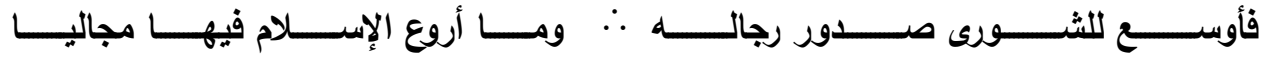

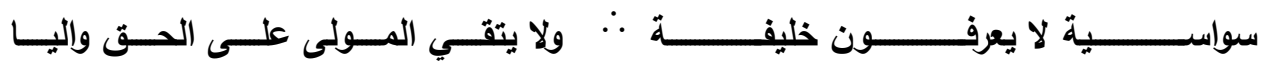

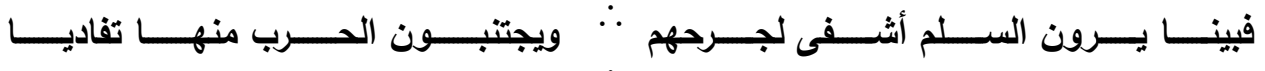




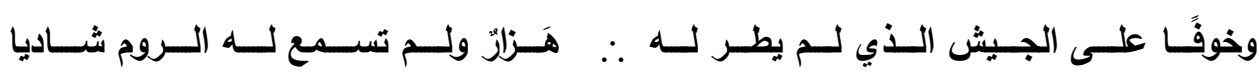

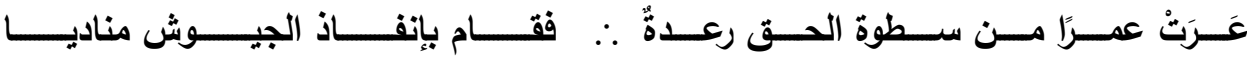

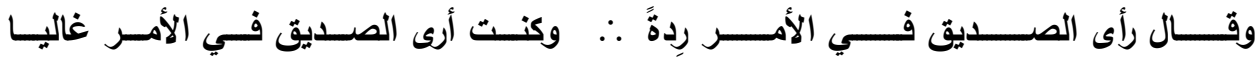

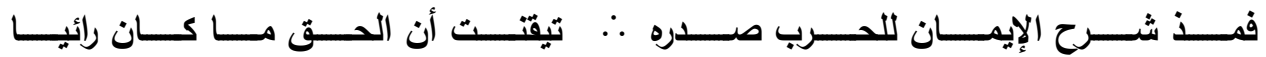

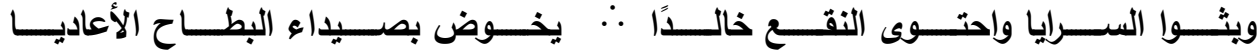

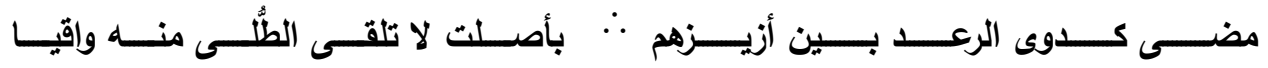

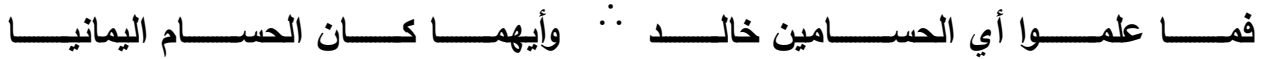

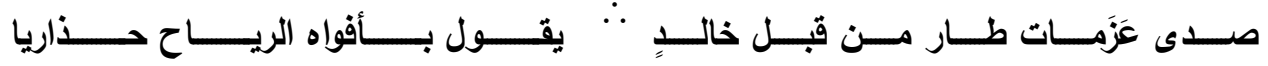

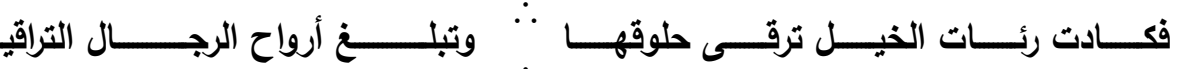

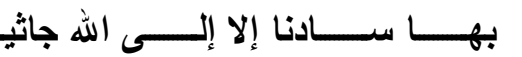

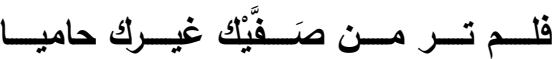

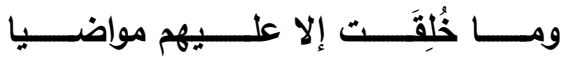

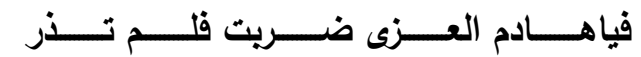

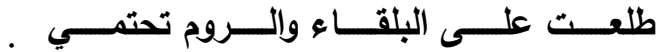

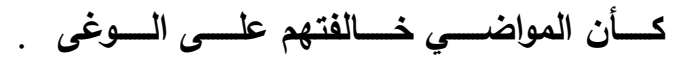

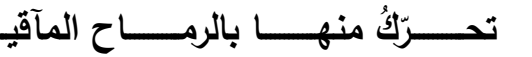

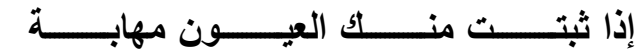

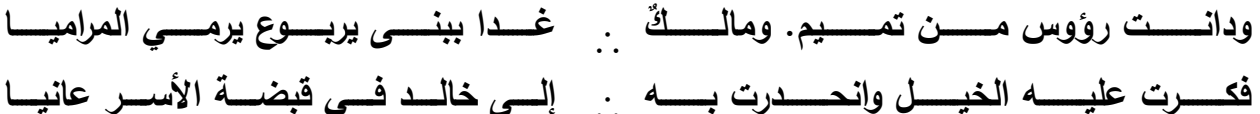

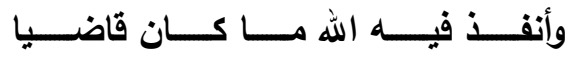

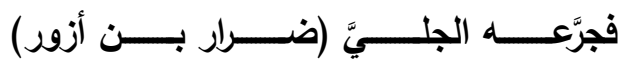
تخاذله تحت الإتـاوة شاكيا ترى سجنهـ بالجدب ظلمـاً وتتقى

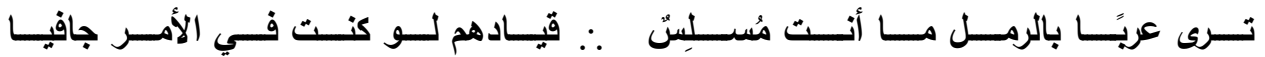

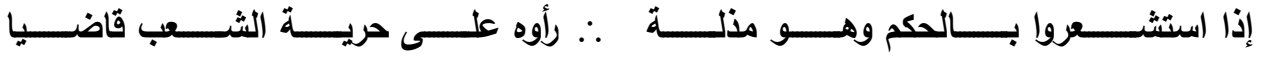

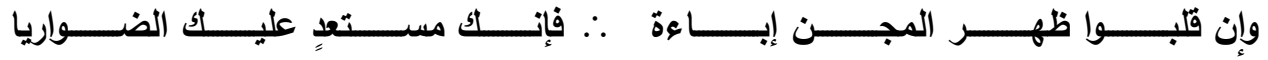

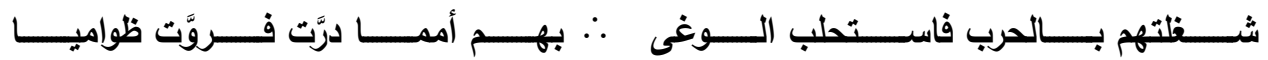

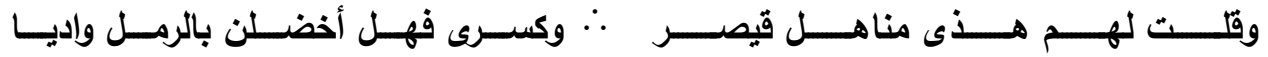

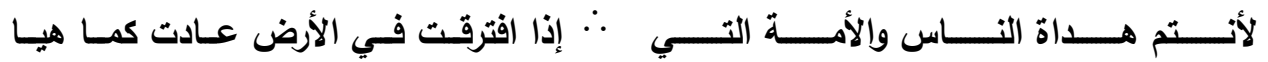

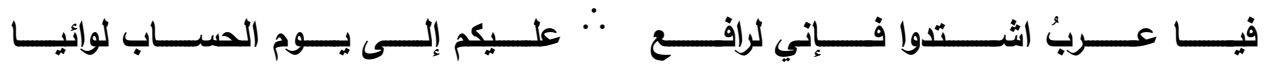

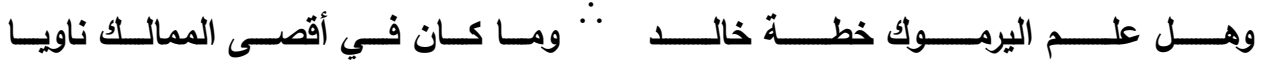

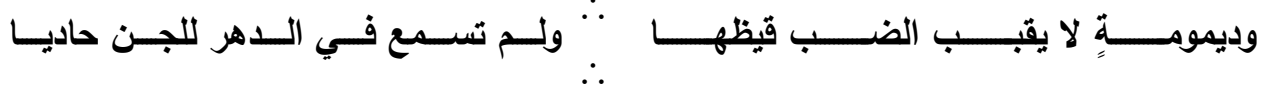




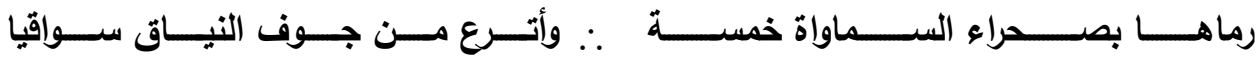

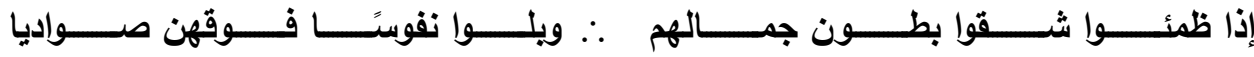

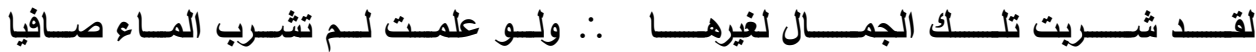

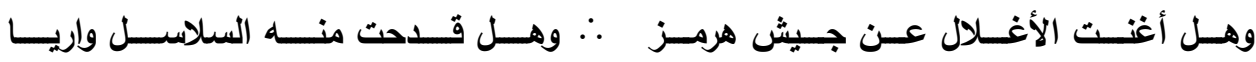

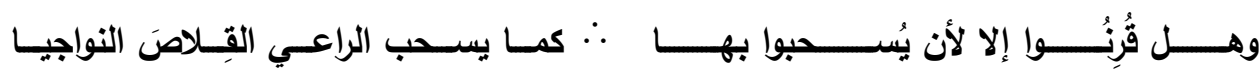

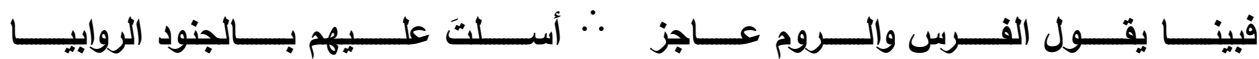

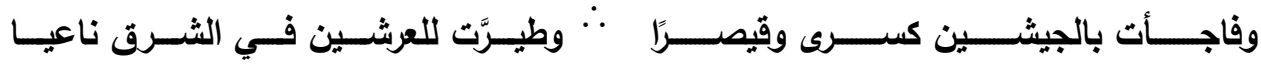

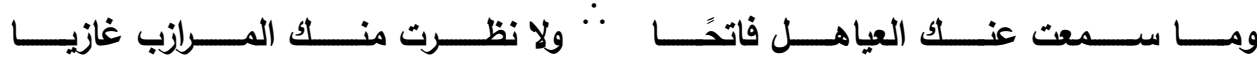

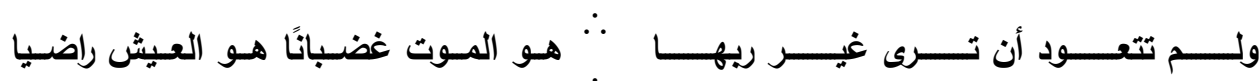

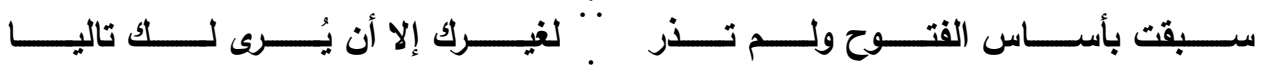

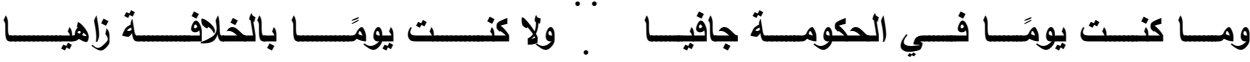

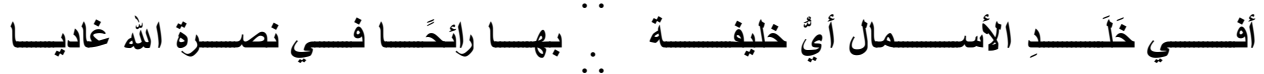

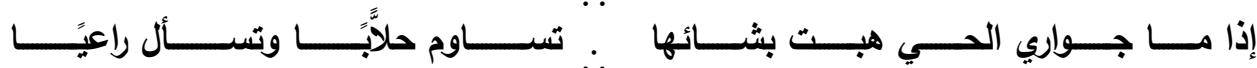

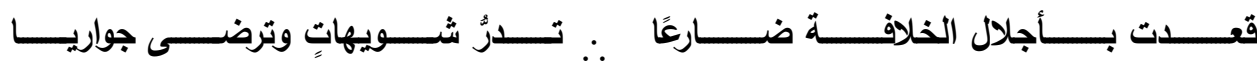
․ لقد دهم الركب اليمانسي مخبر لـاجل

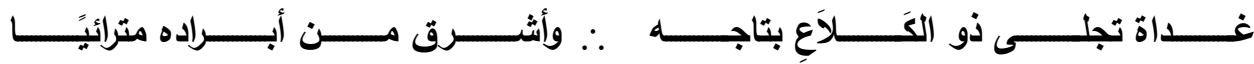

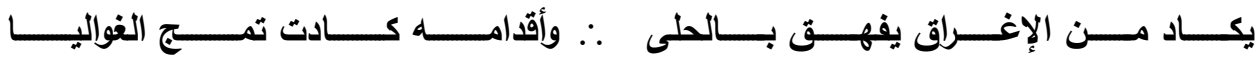

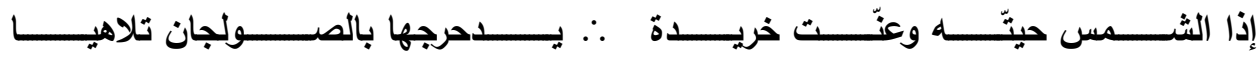

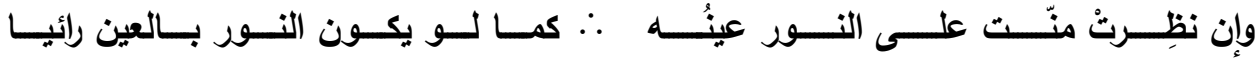

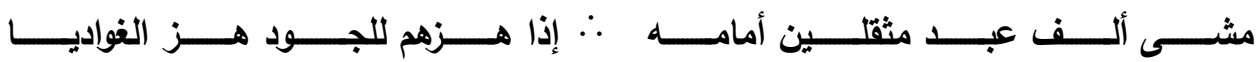

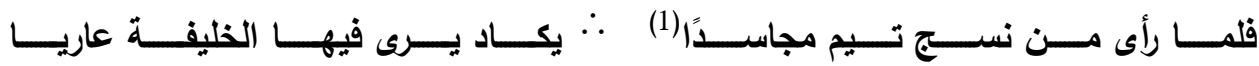

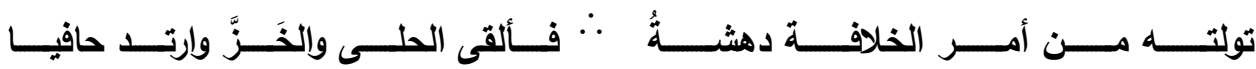
(1) المجسد القميص الذي يلي البدن. أي لما رأوا أقمصه من نسج تيم الهه قبيلة أبي بكر ... 


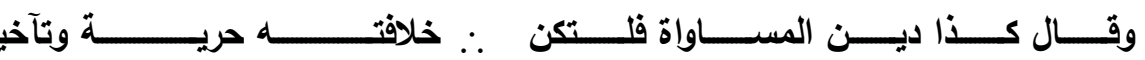

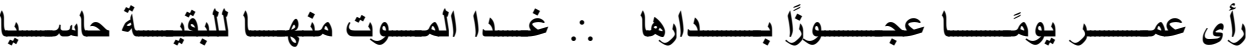

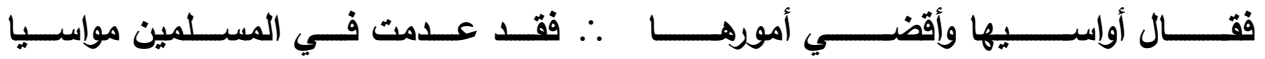

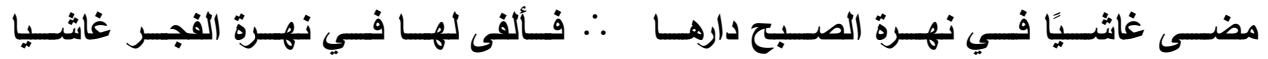

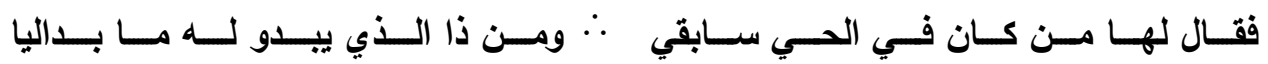

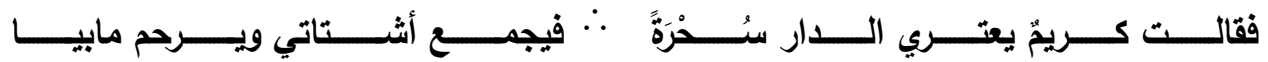

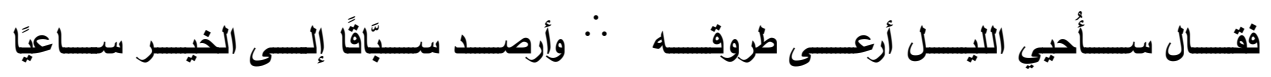

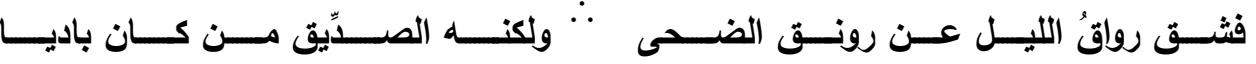

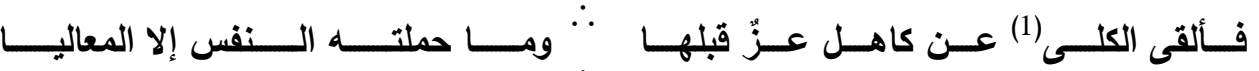

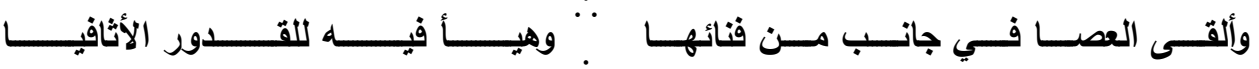

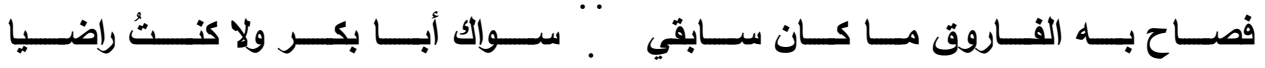

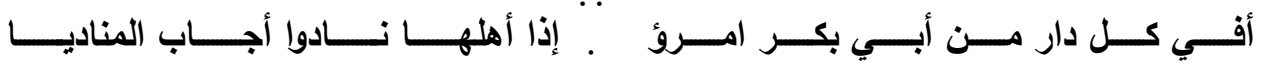

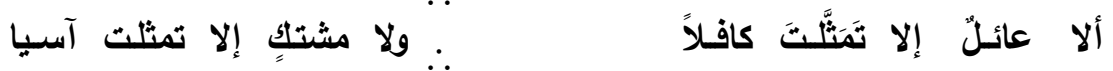




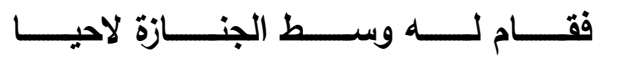

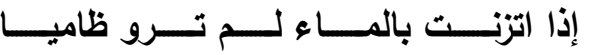

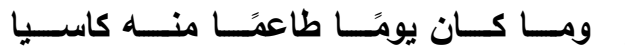

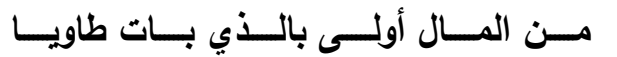
L هم وردائي

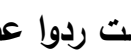
إذا مـ تقاضـــــــــها مـــــــهم وردوا صــــــــافيا

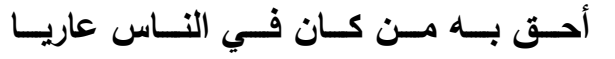

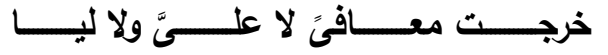

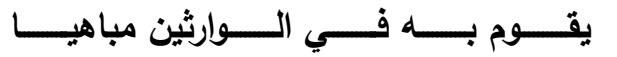

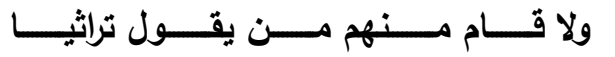

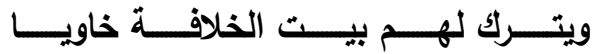

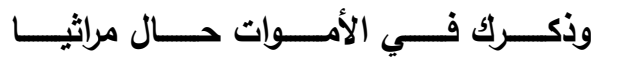

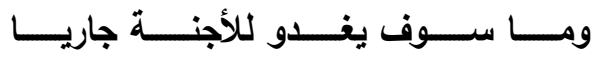

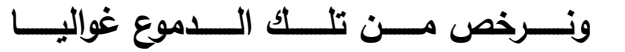

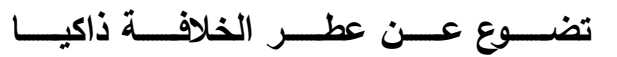

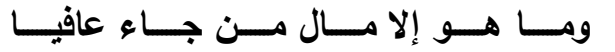

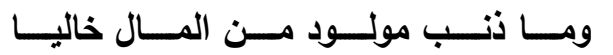

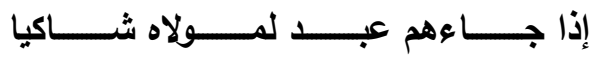

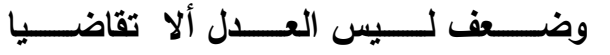

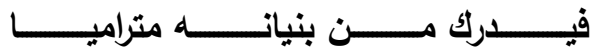
تـــــوارت عــــن الأبصـــــار إلا بواقيـ

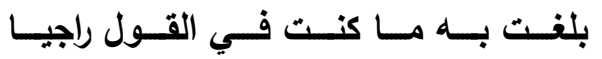
فأنى أرى الأصبـاح تتلو الدياجيا

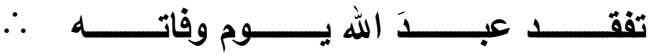

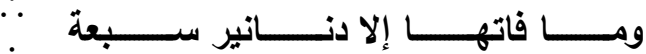
فصــاح تــراث المســلمين ومـــا لهــم ! ولكــن أى مـــازاد عــن حاجــة (بنـــهـ

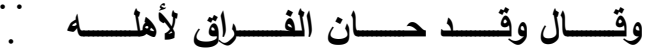

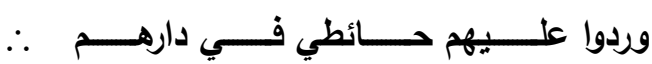

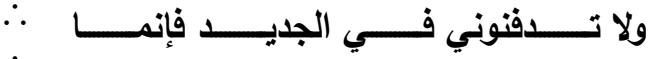

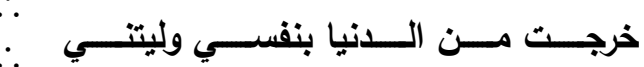

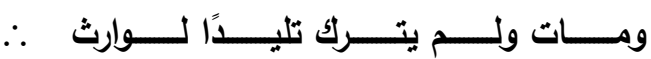

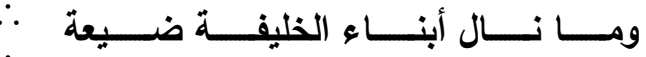

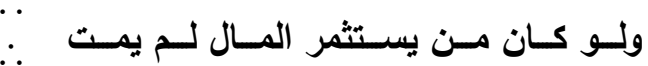

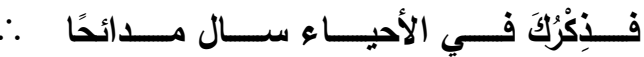

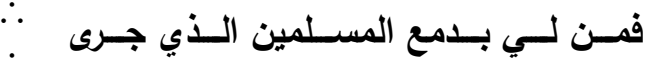

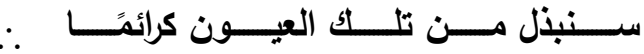

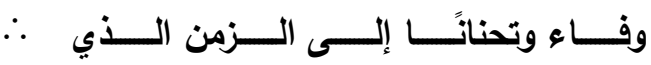

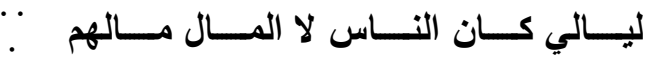

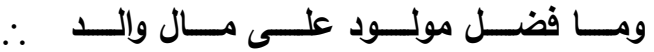

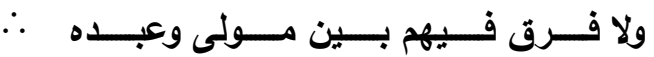

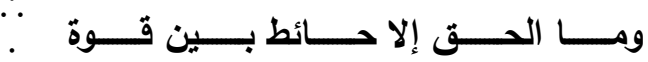

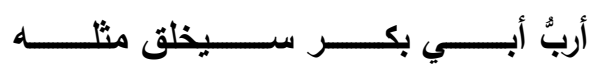

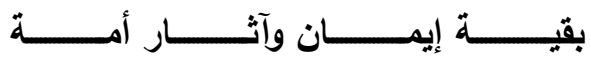

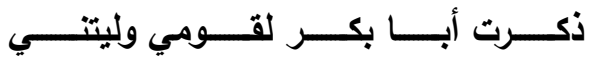
لعل سراة الدهر تبلغ فجره 


\section{الكناية في تصوير مناجاة الشاعر للصديق (c)}

\section{واعتذاره للرسول (م)}

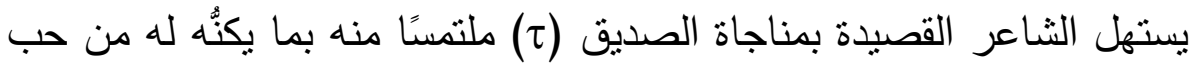
- أن يأذن له بأن يفضي بما في نفسه من تعداد صفاته (ح)، وأن يعتذر لرسول

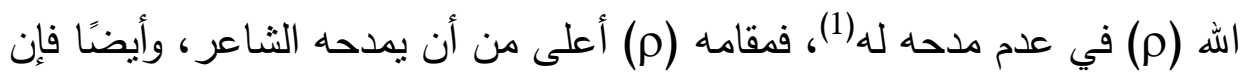

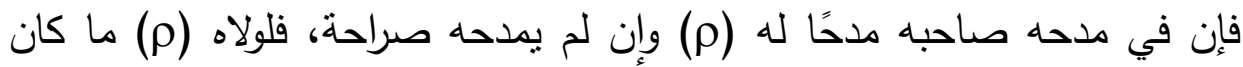
لأبي بكر (ح) أن يصل إلى ما وصل إليه. يجسد الثاعر هذا المعنى قائلاً:

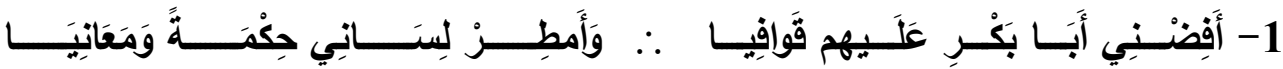

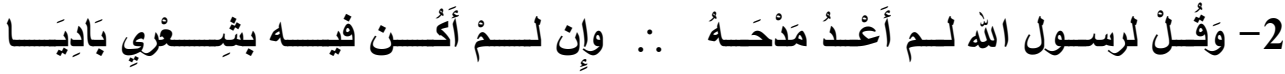

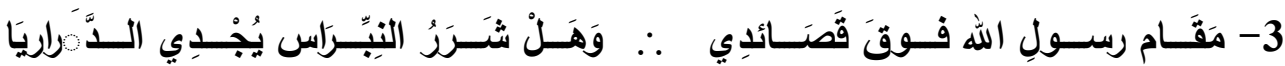

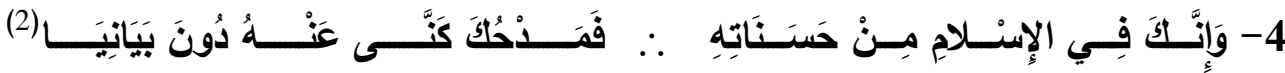

يبدو أن الثـاعر قد أراد من خـلال تصدير قصبدته بالاعتذار لرسول اله (م) أن يعلّق

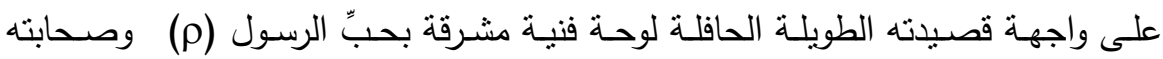

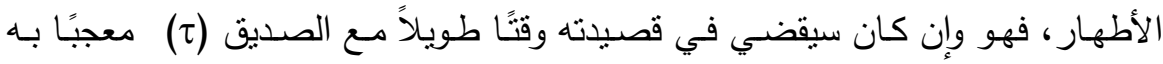
وبسيرته فلن ينسيه ذلك دور النبي (م) في ما آل إليه الصديق، مؤكدًا ذلك بقوله:

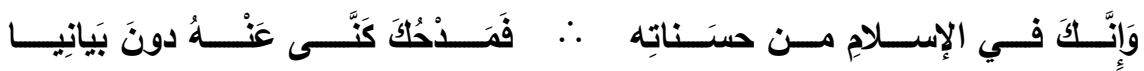

$$
\text { مما يؤكد على براعة الثاعر ، وشدة وعيه. الديوان (302/2). }
$$
(2) النبراس: المصباح، الدراري: الكواكب المتلألئة. 
وقد اشتملت هذه الأبيات على جل صور البيان ومن بينها الكناية، وذلك في

البيت الثالث حيث قوله:

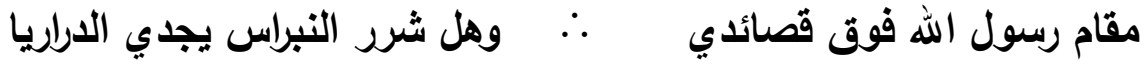

فالثطر الثاني من البيت "وهل شرر النبراس يجدي الدراريا" كناية عن علو

منزلة رسول الله (م) وعدم وتأثره بمدح المادحين، فمقامه أعلى من أن تعبر عنه قصائد الشعراء، ومنزلته أسمى من أن ترفعها بلاغة المتكلمّين. والمعنى الحقيقي لهذا التركيب "وهل شرر النبراس يجدي الدراريا". أن الكواكب السماوية المتلألئة لا تتأثز بضوء المصباح الأرضي حيث لا يزبد في ضوئها شينًا، ولكن هذا المعنى ليس مقصود الثاعر، وإنما أراد ما وراءه أو معنى المعنى - كما يسميه الإمام عبد القاهر - وهو عدم تأثر الرسول (م) بمدح من يمدحه للتدليل على علو منزلته. فالمذكور هنا مستلزم للمستور، وهي كناية عن صفة قريبة كما هو واضح.

وإيثار الكناية على الحقيقة هنا دليل ساطع وحجة دامغة على عدم تأثر الرسول (م) بالمدح لأن من طبيعتها أنها كدعوى الثيء ببينة وبرهان، فضلاً عن أنها صورت المعقول "علو المنزلة" في صورة محسوسة مما يجعله برسخ في الأذهان، وتقنع به العقول. ولهذه الكناية خصوصية تعبيرية دقيقة لأن الثاعر لم يتوصل

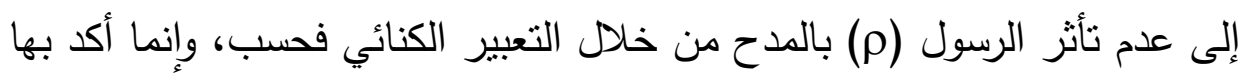
ما سبق أن ذكره صراحة في الثطر الأول من البيت وهو قوله: "مقام رسول الله فوق قصائدي". مما يبالغ في روعة الكناية، ويؤكد دورها في تثبيت المعاني. وضاعف من روعة الكناية هنا تولدها من رحم التشبيه الضدني المستفاد من نفس التركيب الدال على الكناية "وهل شرر النبراس يجدي الدراريا". 
كما أن ورود هذه الألوان البيانية في صورة الاستفهام مما يؤكد المعنى ويقويه، حيث يجد المتلقي نفسه أمام سؤال مطلوب الجواب، فإذا بالجواب تأكيد للمعنى نفسه الذي يتضمنه السؤال. مما بدل على حسّ الثناعر. وحنكته في اختيار الألوان المؤدية للغرض. كما تلحظ المبالغة أيضًا في إفراد النبراس وإضافة الثرر إليه، وجمع الدراري ليدل على أنه مهما كثر المادحون للرسول (م) فما يقولونه هو شيء يسير بجانب عظمة المصطفى (م) فهو ليس كوكبًا واحدًا وإنما كواكب متعددة متلألئة، وفي هذا إتاحة الفرصة لقبول عذر الثاعر في عدم مدح الرسول

وبمعاودة التأمل في الكناية نجد أنها متتاغمة مع مقام الاعتذار الذي يستجمع

فيه الثاعر كل الأدلة التي توصله إلى قبول اعتذاره، ولا شك أن الكناية هنا من أقوى الأدلة التي توصله إلى مبتغاه. 
الكناية في تصوير حالة الشاعر حين أقدم

$$
\text { على مدح الصديق (ح) }
$$

يقول الثاعر:

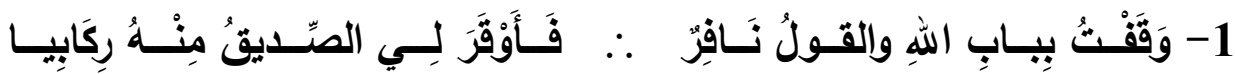

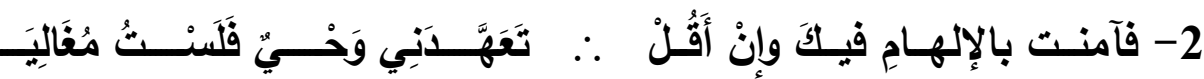

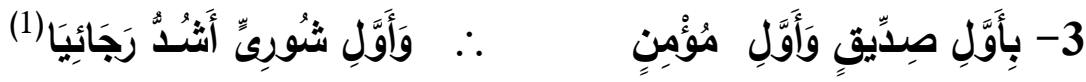
والأبيات تصف حالتين مختلفتين للثاعر تجاه ممدوحه: الحالة الأولى: حالة العجز والوهن واليأس التي اعترته حين قام على تجسيد مناقب الصديق (ح) خوفًا من ألا يصل إلى ما يريد.

الحالة الثانية: حالة القدرة والتحفز التي توفرت لديه بعد الحالة الأولى نتيجة حبّه الثديد للصديق (ح).

وقد صور البيت الأول الحالتين خير تصوير، فالشطر الأول "وققت بباب الله والقول نافر" تصوير للحالة الأولى؛ لأن قوله "والقول نافر" كناية عن صفة العجز ، حيث يدل هذا التركيب على عجز الثاعر ورهبته حين قدم على مدح الصديق

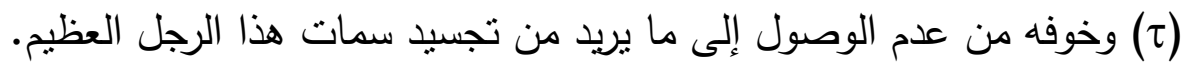
وبالتأمل يتضح أن الكناية هنا قد أبرزت المعنى المقصود وأظهرته في صورة محسوسة وذلك بتصوير حالة الثاعر حين أقدم على مدح الصديق (ح) وإظهار (1) الديوان (302/2)، ومعنى أول شورى: أول من أخذ بمبدأ الثورى بعد النبي (م). 
شدة رهبته وخوفه، فناسب أن يكنى عن العجز بنفور القول وشروده نظرًا لعظم مكانة الممدوح وعلو منزلته.

وضاعف من جمال الكناية هنا قيامها على استعارة لطيفة، وذلك بتشبيه استعصاء القول على الثاعر وعجزه عن تجسيد مآثز الصديق (ح) بالناقة الثرود على طريق الاستعارة المكنية، مبالغة في التصوير ، وتأكيدًا للمعنى. وفي الشطر الثاني من البيت نجد قوله "فأوقر لي الصديق منه ركابيا" كناية عن القدرة التامة والتوفر القوي على تجسيد هذه المآثر. وتأتي هذه الكناية في مقابلة الكناية السابقة، فإذا كانت الكناية السابقة تصور عجز الثاعر وضياع الكلام منه حين أقدم على مدح الصديق (ح) فإن هذه الكناية تصور أثز حب الثاعر للصديق (ح) في انقياد المعاني للثاعر ، وإسلاسها القيادله، ولذلك فإنه يتضح للمتأمل هذا الارتباط الوثيق بين هذا البيت وبين البيت الأول (مطلع القصيدة) وهو قوله:

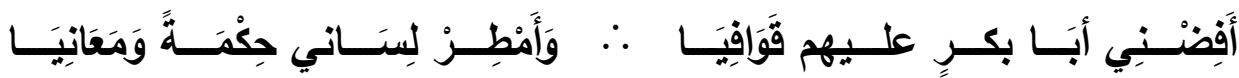

فلولا أن الصديق (ح) قد أفاض عليه بالقوافي والمعاني لظل القول نافرًا، والمعاني شاردة.

وكما قامت الكناية السابقة على استعارة مكنية رائقة قامت هذه الكناية أيضًا على استعارة قربية منها من نفس نوعها دخولاً في المبالغة، وزيادة في توضيح الصورة. 
وقد عدل الثاعر عن الحقيقة إلى الكناية في الموضعين السابقين ليقدم لنا المعنى ومعه دليل ثبوته مما يجعله يتمكن في النفس فما لا شك فيه (أن دعوى لئ الثيء ببينة أبلغ في إثباته من دعواه بلا بينة". (1) هذا فضلاً عما تشتمل عليه الكناية من تشخيص معجب، وتصوير خلاب. فإذا تركنا هاتين الكنايتين وذهبنا إلى البيت الأخير فإننا نجد أنواعًا مختلفة وألوانًا متعددة من الكناية وذلك قوله:

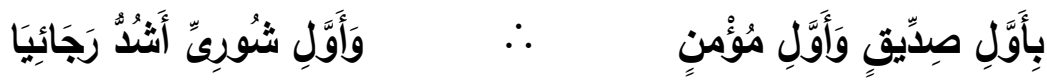

وقد اثتمل هذا البيت على أربع كنايات جاءت الثلاث الأول فيها تمهيدًا لما

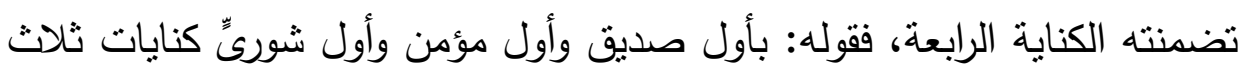
عن موصوف هو سيدنا أبو بكر (ح) والثاعر بدلاً من أن يقول: بأبي بكر .....

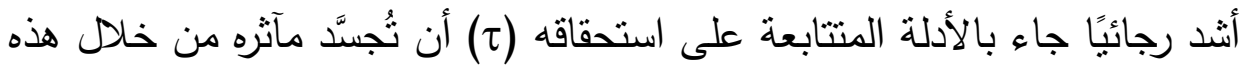
الأوصاف المتعددة الدالة عليه (ح). وكل صفة من هذه الصفات خاصة بأبي بكر (ح) لا تتعداه ولا يتصف بها غيره حتى لا يكون هنالك خلط أو تداخل، فالبلاغيون يشترطون لهذا النوع من الكناية (الكناية عن موصوف) أن نكون الصفة أو الصفات المذكورة من خصائص الموصوف المكني عنه لا يشترك معه فيها غيره. (2) وقد اختار الثاعر هذه الصفات دون غيرها في الدلالة على الموصوف لأنها أخص صفاته (c). (2) ينظر : شروح التلخيص (1250/4). 
وتكمن أفضلية الكناية هنا في أنها قدمت لنا الحديث عن سيدنا أبي بكر (ح)

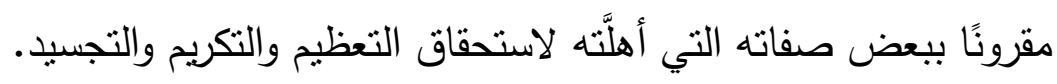

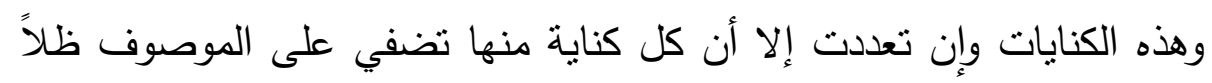

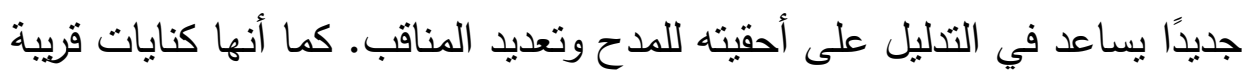

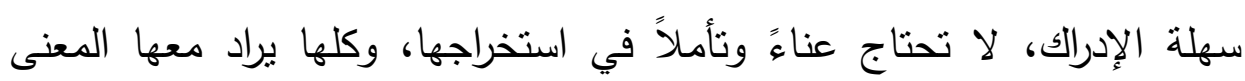
الحقيقي، مما يزيد معناها ثراءً وأبلغية. وقد برع الثناعر في إيراده لهذه الكنايات المتعددة الدالة على موصوف والئه واحد

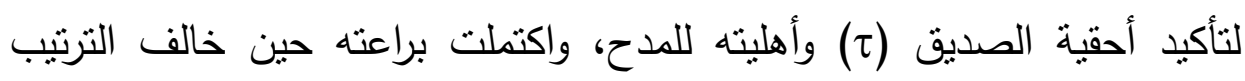

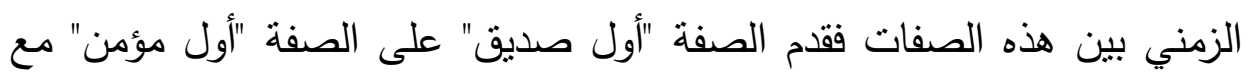

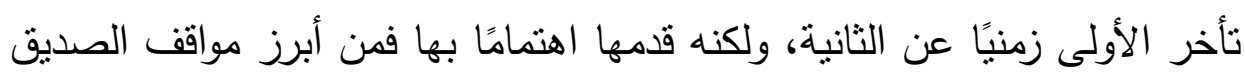

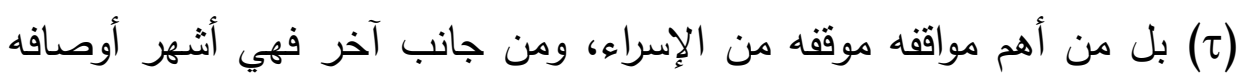
ذيوعًا وانتشارًا.

وبالرغم مما ذكرته عن هذه الكنايات الثنلاث (عن موصوف)، وما اثتنملت عليه

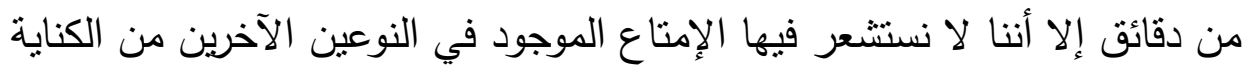

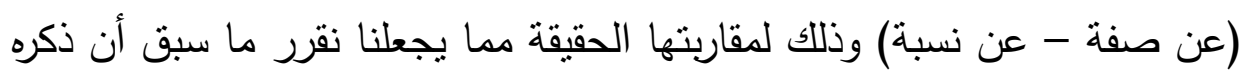
البلاغيون من أن هذا النوع (الكناية عن موصوف) "ليس فيه ما في القسمين

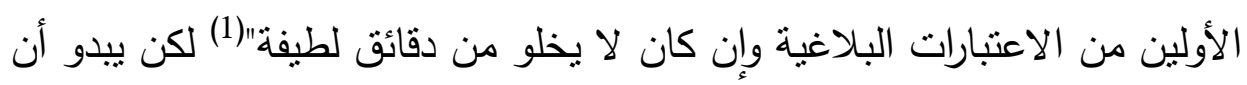
الثاعر ذكر هذه الكنايات - كما سبق أن ذكرت - ليتوصل بهم إلى الكناية لإن لئل

(1) التصوير اليباني: د/محمد أبو موسى، (409). 
الرائعة في آخر البيت وهي قوله: "أثد رجائيًا" وهو كناية عن الاستعداد والتهيؤ

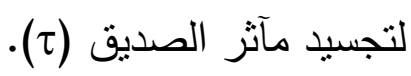
وقد عدل الثاعر عن هذا اللفظ الصريح إلى عبارة "أنثد رجائيًا" لما فيها من مبالغة، حيث تصور الاستعداد وهو معنوي في صورة محسوسة، وتثبته ببرهان.

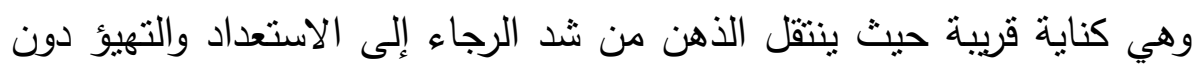
واسطة.

والكناية هنا تكثف عن مدى الاستعداد والتحفز من الثشاعر في سبيل الوصول إلى ما يتغياه في إيجاز بديع، وتصوير رائع.

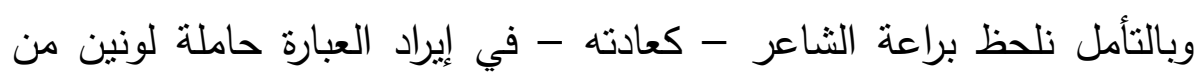

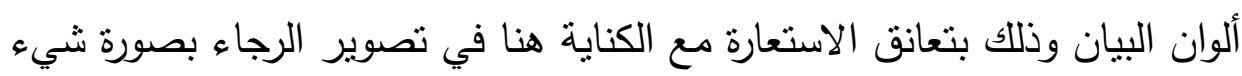

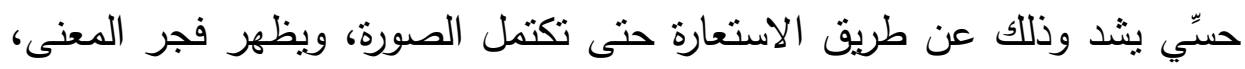
ولا شك أن هذا يعود على أسلوب الكناية بالقوة والمبالغة. 


\section{الكناية في تصوير أحقِّيَّته في الخلافة}

وفي هذا المعنى يقول الثاعر :

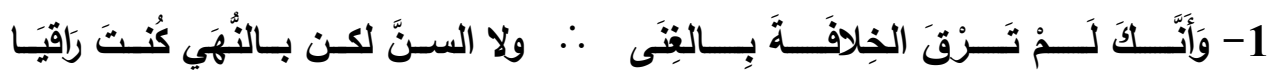

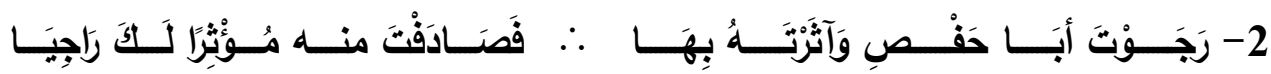

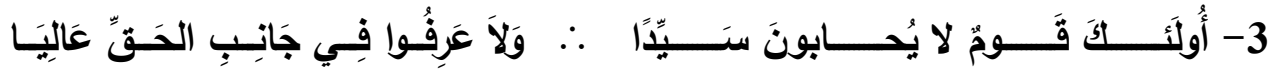

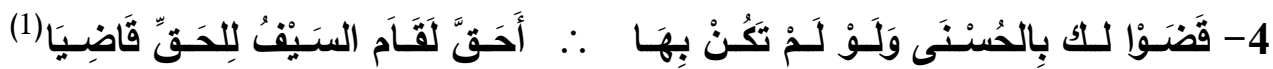
(1) قََاضِ

والأبيات كاشفة عن أحقية الصديق (ح) بخلافة المسلمين، وهذه الأحقية لم تأت لكونه غنيًا ينفق بسخاء، ولا لكونه أكبر القوم سنَّا، ولكنه العقل الراجح، والإيمان القوي، والقدرة على تحمل أعباء الدعوة وحسن القيام بها. وموضع الكناية في البيت الثالث حيث قوله:

\section{أولئكَكَ قومُ لا يُحَابونَ سَيِّاً}

وقد حفل كل من شطري البيت بكناية عن نفس المعنى التي تدل عليه الكناية الأخرى، فقوله: "لا يحابون سيدا" وقوله: "ولا عرفوا في جانب الحق عاليا" كناية عن العدل، وعدم المراءاة والمجاملة، فهم لم يبايعوا الصديق (ح) لغناه ولا لكبر سنه ولكن لأحقيته في الخلاقة، وامتلاكه كل مقوّماتها. والحقيقة أن مظاهر عدل الصحابة - رضوان الله عليهح - كثيرة، لكن الثاعر يلتقط لنا دليلين متوافقين مع مقام الاستحقاق توصلاً إلى ما يربد، فهم لا يحابون سيدا ولا يعرفون في جانب 
الحق عاليا مما يدل على عدم محاباتهم للصديق (ح) وهذا بدوره يدل على أنه أهل

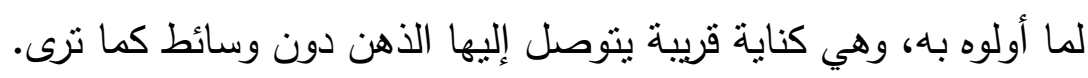

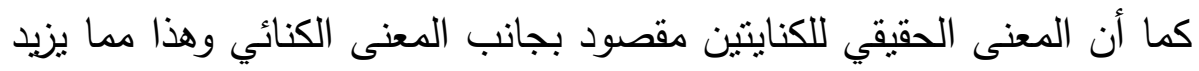

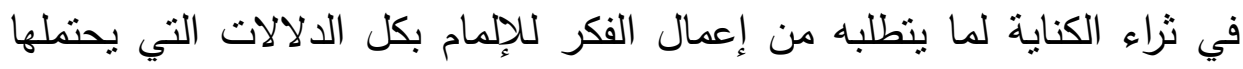
الأسلوب. 


\section{الكناية في تصوير فصاحته (ح)}

$$
\text { وفي هذا المعنى يقول الثناعر: }
$$

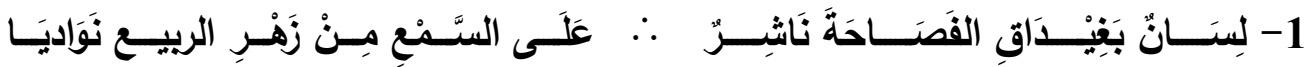

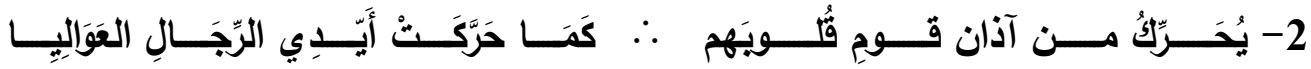

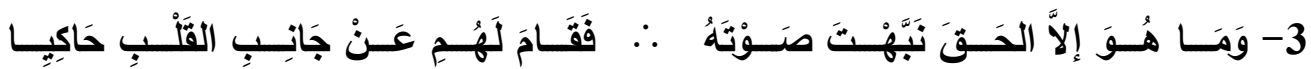

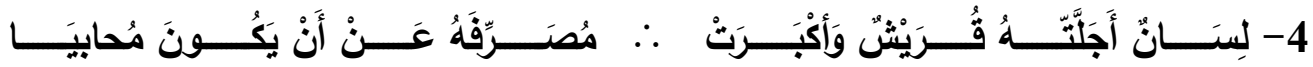

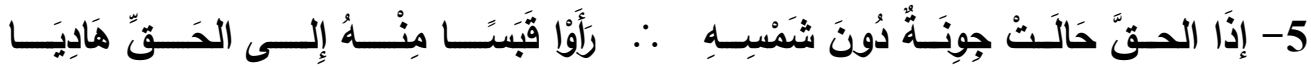

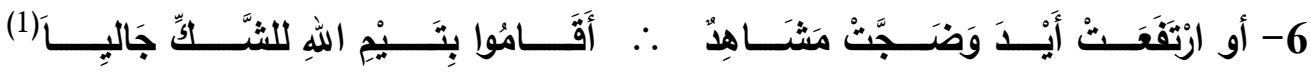

والأبيات تتحدث عن فصاحة الصديق (ح) وتبرز دور فصاحته وعذوبة منطقه في دعم مسيرة الإسلام، وتقوية شوكته، وإيصال مفاهيمه الصحيحة إلى الناس، ونشر مبادئه السمحة بين أهل مكة، والاهتداء بآرائه الثاقبة خاصة حين تدلهم الخطوب، وتطبق الظلمات.

وقد تعددت مواطن ورود الكناية في هذا المقام بطريقة لافتة للنظر، ففي البيت

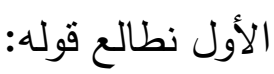

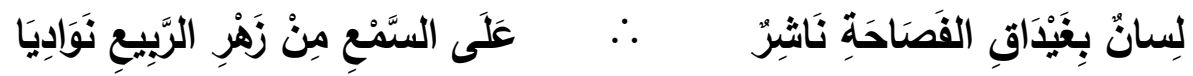

(1) الديوان (303/2، 304). وغيداق الفصاحة: جزالتها وعُذوبتها. العوالي: السيوف. الجونة:

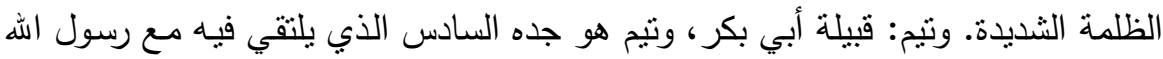

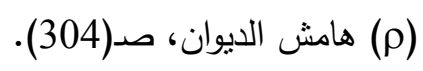


والبيت بتمامه كناية عن طيب كلام الصديق (ح) وعذوبة منطقه وفصاحته، لأنه لا يفعل ذلك إلا الكلام الطيب الفصيح الذي تبتهج له النفوس. وبالتأمل يتبين

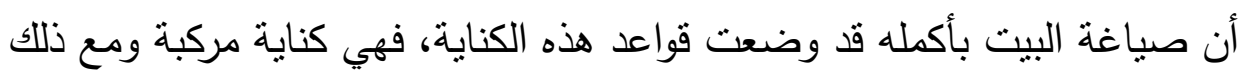
فهي قريبة لا تتطلب عناءً في استخراجها، وقد أنثار ابن الأثثر إلى أن الكناية المركبة أعلى درجة من المفردة فقال: "الكناية إذا وردت على طريق اللفظ المركب كانت شديدة المناسبة واضحة الثبهية، وإذا وردت على طريق اللفظ المفرد لم تكن بتلك الدرجة في قوة المناسبة والمشابهة، ألا ترى إلى قولهم: "فلان نقى الثوب" وقولهم: "اللمس" كناية عن الجماع فإن نقاء الثوب أثند مناسبة وأوضح شبهًا، لأنا إذا قلنا نقاء الثوب من الدنس كنزاهة العرض من العيوب اتضحت المشابهة، ووجدت المناسبة بين الكناية والمكني عنه شديدة الملاعمة، وإذا قلنا اللمس كلهن كالجماع لم يكن بتلك الدرجة في قوة المشابهة". (1) كما أن الكناية هنا أضفت على كلام الصديق (ح) صفة الأريحية والسرور عند

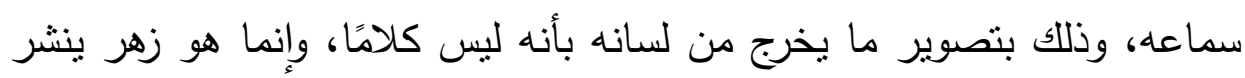
على الأسماع أطيب الروائح، وذللك مما يبالغ في عذوبته وفصاحته. وبالتأمل في هذه الكناية نلحظ أنها تعانقت مع لونين من ألوان المجاز: المرسل: في التعبير عن الكلام باللسان في مطلع البيث لعلاقة الآلية، إذ الكلام هو الموسوم بالفصاحة، واللسان آلته. والعقلي: في إسناد الزهر للربيع في الشطر الثاني من البيت لعلاقة الزمانية، فالبيت يفيض بالمجاز بنوعيه: (المرسل والعقلي) 
المتعانقين مع الكناية لإبراز أثر كلام الصديق (ح) في استمالة النفوس واستجابتها لما يدعو إليه عن قناعة وحب.

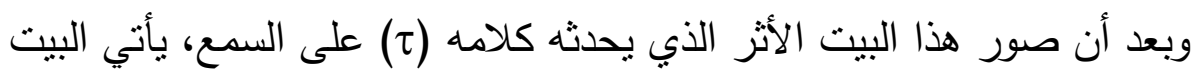

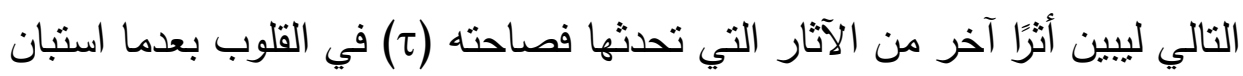
أثزه على الأسماع وذللك في قوله:

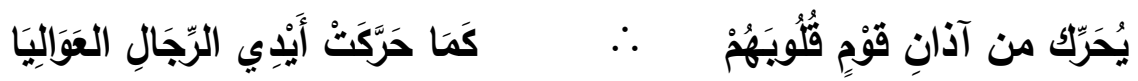
وفي البيت تتجلى الكناية في أبهى صورها في قوله: "يحرّك من آذان قوم قلوبهم" كناية عن شدة نأثيره في الناس لقوة فصاحته. وهذه الكناية لا يمكن معها إرادة المعنى الحقيقي نظرًا لاستحالته.

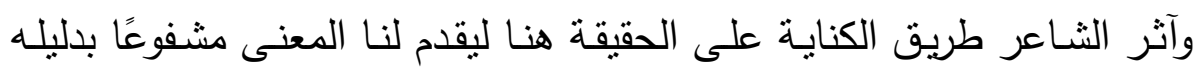

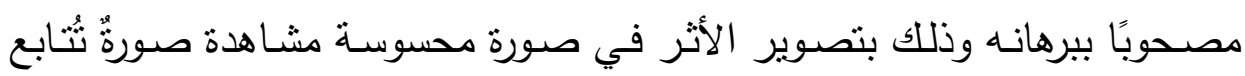

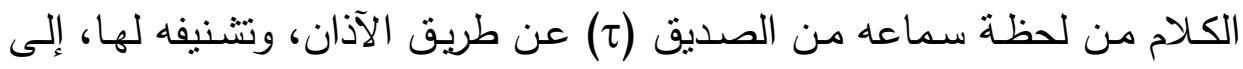

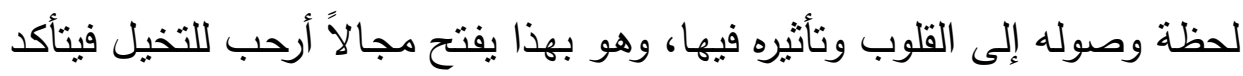
المعنى في النفس حيث لم يعد لها تثوف إلى المزيد لأنها رأته مشاهدًا محسوسًا. كما أن هذه الكناية نأتي كليل آخر يضاف إلى الكناية السابقة في البيت الأول

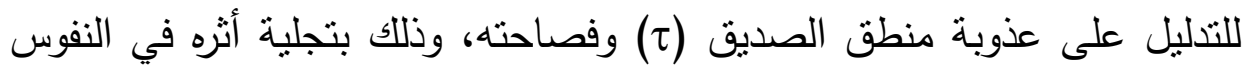

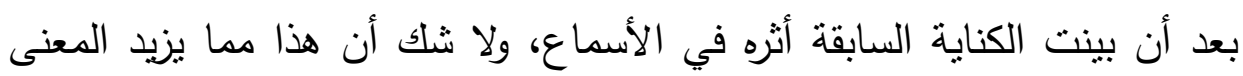

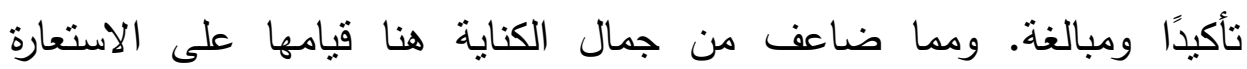
التصريحية التبعية في "يحرّك" مما يكسوها جلالاً وأبلغية.

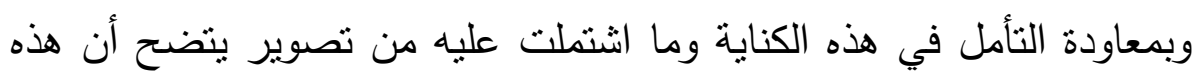

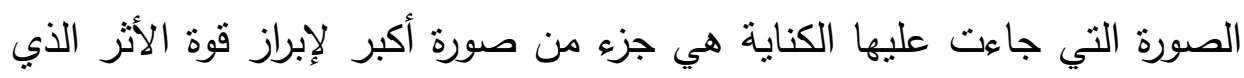


يحدثه كلام الصديق (ح) في نفوس منلقية، وذلك من خلال التصوير بالتشبيه

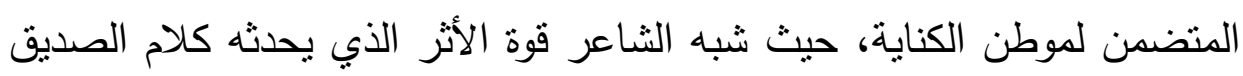
(ح) في النفوس، وشدة تحريكه لها بثدة تحريك أيدي الرجال للسيوف، واستتفارها

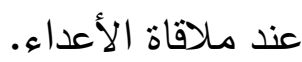

ولا شك أن تحريك السيوف مما يحدث زلزلة في نفوس العدو وبخاصة إذا كان

من يحركها مما ينطبق عليه وصف "الرجال الرال".

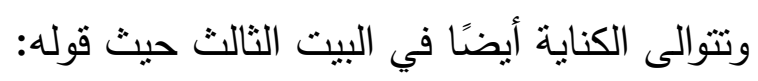

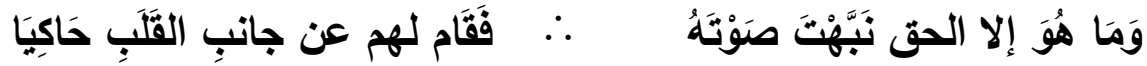
وموطن الثاهد قوله: "عن جانب القلب" كناية عن مطابقة المقول للواقع،

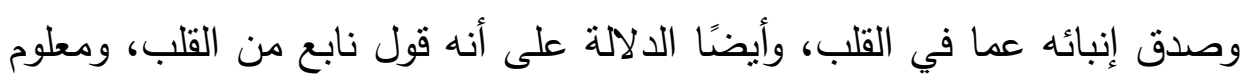
أنه ما كان من القلب وصل للقلب.

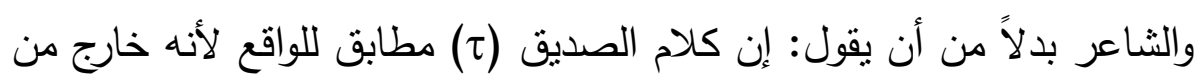

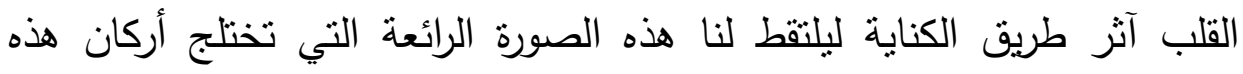

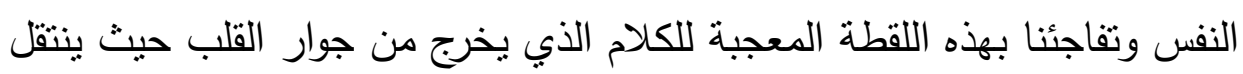
الذهن منه إلى الإقرار بصدق هذا القول الذي قراره جانب القلب. وقد سبقت هذه الكناية باستعارة رائعة في "نبهت صوته" ليكتمل التصوير،

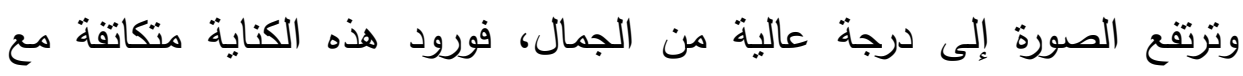

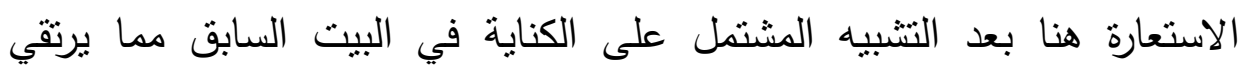

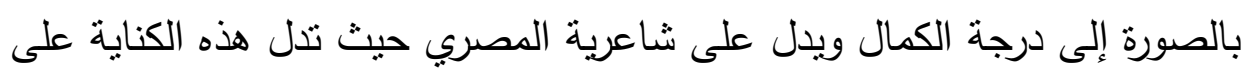

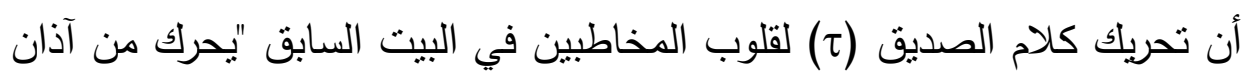

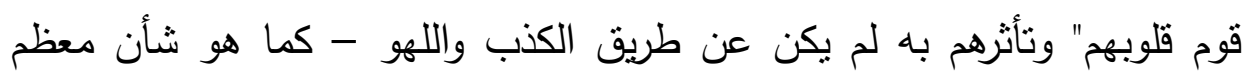


الكلام المعجب - وإنما كان عن طريق الدق والصدق المدلول عليه صراحة من

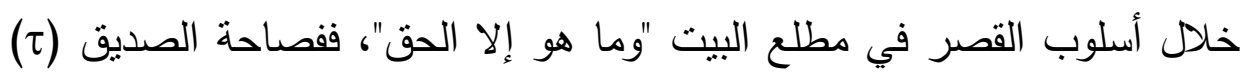

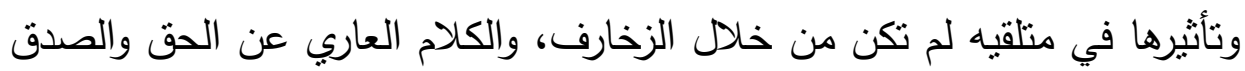
وإنما تسنمد قوتها من معينهما.

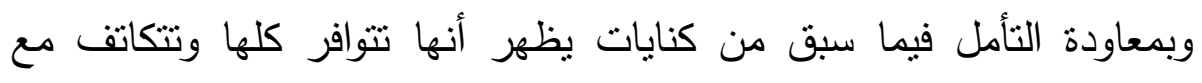

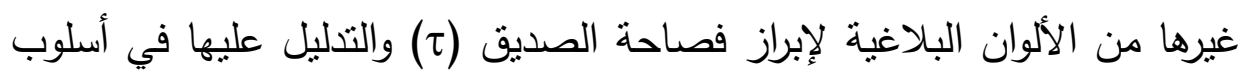
رائع، ومعانٍ رائقة.

وفي البيت الخامس والسادس يتابع الثناعر حديثه عن فصاحة الصديق، ووضوح رأيه، والاهتداء به خاصة عند الملمات والثدائد فنراه يقول:

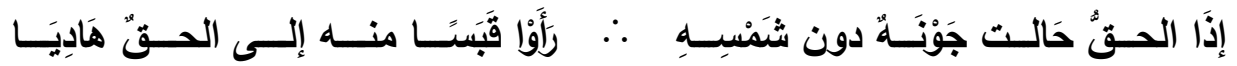

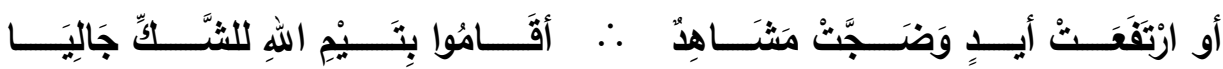

وقد انشنل البيتان على أكثر من موضع للكناية، فقوله: "إذا الحق حالت جونه دون شمسه" كناية عن الضلال وغياب الحقائق.

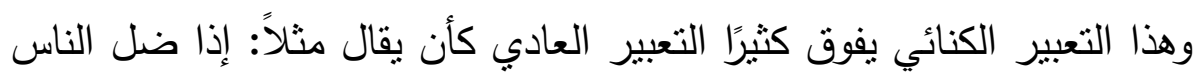

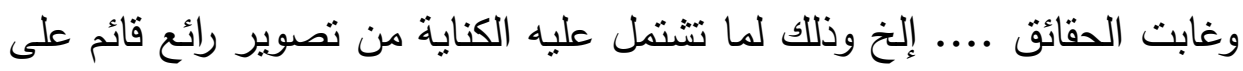
الاستعارة كما هو قائم على الكناية وذلك بجعله للحق ظلمة وشمسًا، وبجانب هذه 
الاستعارة تتولد الكناية التي لا تفهم من صريح اللفظ، وإنما من لفظ دال على معنى هو ردفه وتابع له فإذا دلَّ التابع أبان عن المتبوع. (1) مـن أجـل هـا كانـت الكنايـة (هـي اللسـان الــي يخاطـب الخـواص الموثـوق بفطانتهم، المعوّل على ذكائهم، وقوة لمحهم، ودقـة فهمهم، وغوصـهم عن مـراد البليغ وشوط قريحته)(2)، مما يجعلها تفوق مرات التعبير العادي. وتتجلى بلاغة الكناية هنا في تشخيصها وإبرازها لدور الصديق (ح) والاهتداء برأيه في هذا الوقت الثديد عندما تغيب الحقائق وتحول الظلمات دون الوصول إلبها.

وفي البيت التالي تأتي كنايتان قريبتان من الكناية السابقة لإبراز أثز الصديق ودوره في الثدائد وذلك في قوله: "أو ارتفعت أيد" كناية عن شدة الخطب وعدم الاهنداء للصواب، وقوله: "وضجت مشاهد" كناية عن التخبط. وتتبدى البلاغـة العاليـة لهاتين الكنايتين في إبرازهمـا لشـدة الخطب والتخبط مصحوبين بدليلهما من ارتفاع للأيدي وهرع للمشـاهد وهذا لا شكك يقوي المعنى إيرائ ويؤكده.

وهكذا صور الثاعر شدة الخطب بكنايتين مختلفتين اشتركتا في الدلالة على

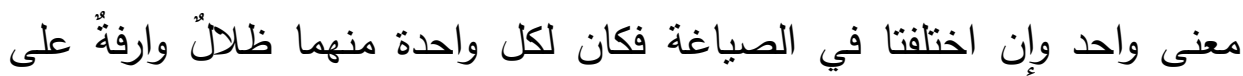

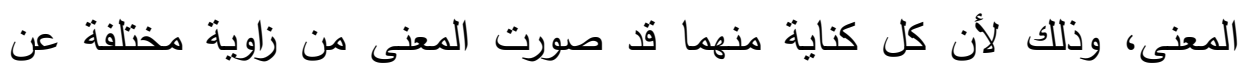

ينظر : نقد الثـعر لقدامـة بن جعفر صـ(157)، ت د/ محمد عبد المنعم خفاجي، مكتبـة

$$
\text { الكليات الأزهرية 1398هـ - 1978م. }
$$

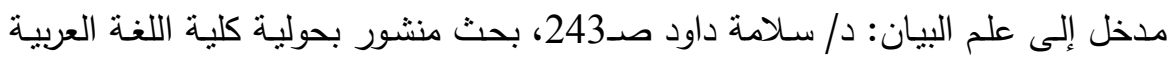

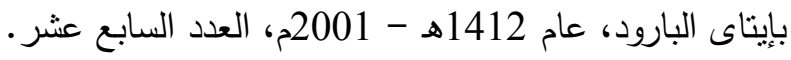


الأخرى لكنها في نفس الوقت دالة على ما تدل عليه الأخرى، وهذا لا شك اكتمال

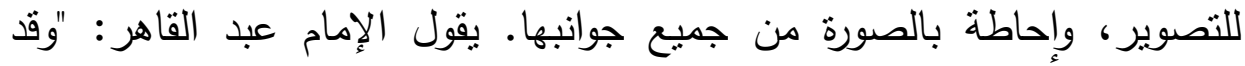

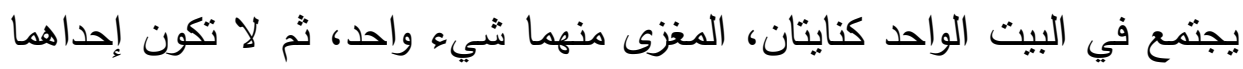
في حكم النظير للأخرى ... مثال ذلك: أنه لا يكون قوله: "جبان الكلب" نظيرًا

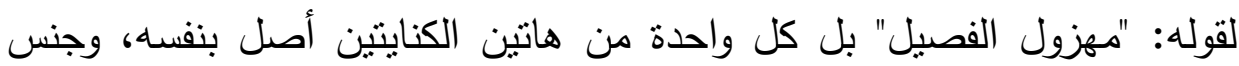
على حدة، وكذلك قول ابن هرمة:

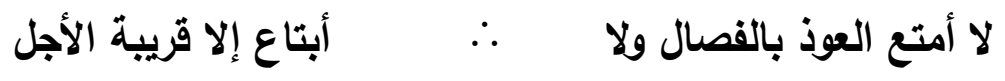
ليس إحدى كنايتيه في حكم النظير للأخرى، وإن كان المكني بهما عنه واحدًا فاعرفه. وليس لنعب هذا الأصل وفروعه وأمتلته وصوره وطرقه ومسالكه حد ونهاية. (1)

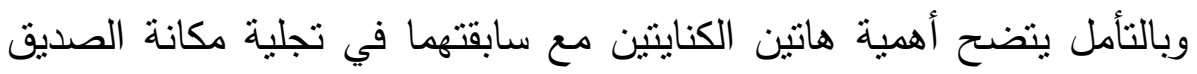

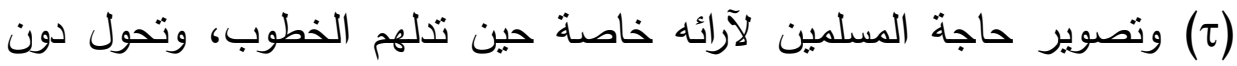
الوصول إلى الحق كثير من المعضلات والغيوم فيكون منه الرأي الصائب، والضوء الثاقب الذي يفكلك أوصال الظلمات ويضيء جوانب الحياة، ويقضي على التى التى الثك، أثتتت الكناية كل ذلك في عبارات رائقة، ومعانٍ شائقة. وبمعاودة التأمل في الأبيات من أولها نلحظ كثرة ورود الكناية في مقام الحديث

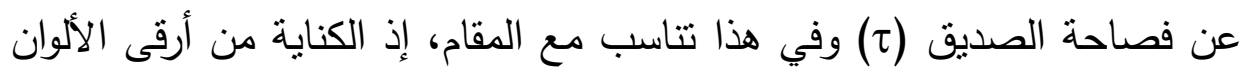
البلاغية التي ترتقي بالكلام إلى أعلى سماوات الفصاحة والمبالغة، فضلاً عن أنها

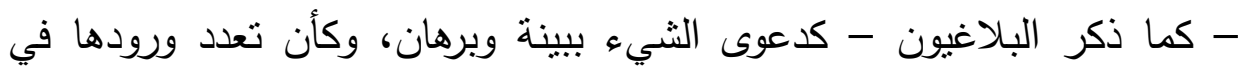
الحديث عن الفصاحة تدليل على فصاحة الصديق (ح) وتوثيقه. 


\section{الكناية في تصوير موقفه من الإسراء}

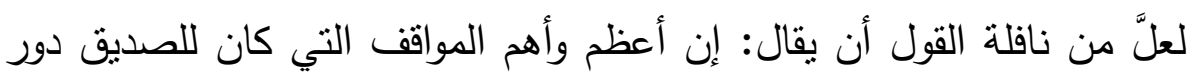
رائد فيها هو موقفه من حادثة الإسراء - والتي كانت سببًا في وصفه بالصديق إني وما حدث فيها من ارتداد بعض ضعاف النفوس ونكوصهم، وكذلك استهزاء الكفار

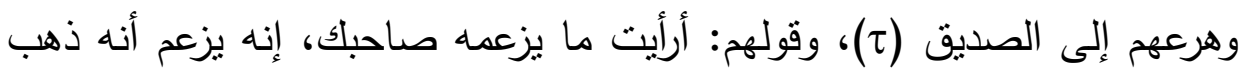
إلى بيت المقدس وعاد في نفس الليلة، ونحن نضرب إليها أكباد الإبل شهرًا ذهابًا وشهرًا إيابًا، ولكن كان للصديق رده الناصع، ودوره الرائد في إحباط كيدهم، ودحر استهزائهم، حيث قال: إن كان قال فقد صدق صدق. يُجَسد الثاعر هذا الموقف المشرق قائلاً:

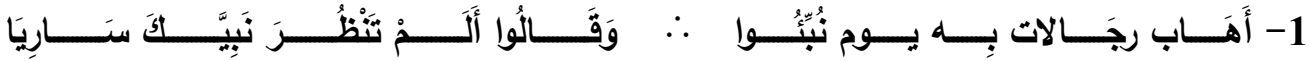

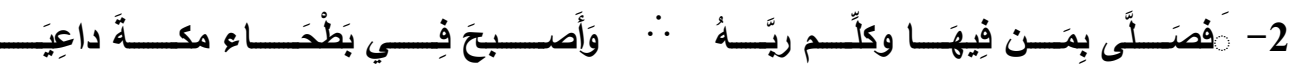

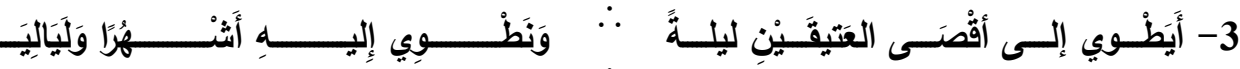

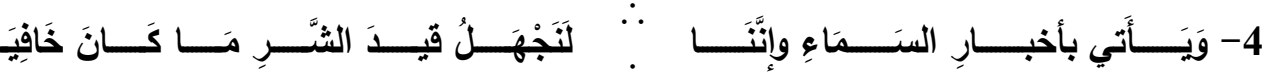

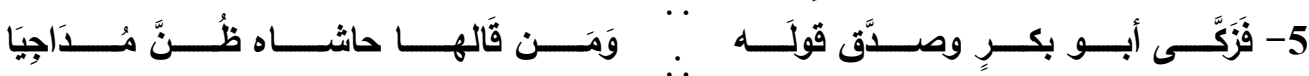

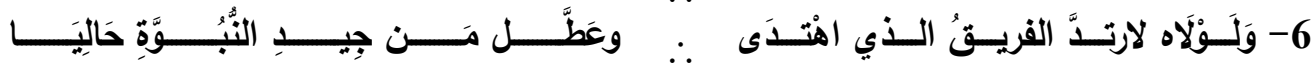

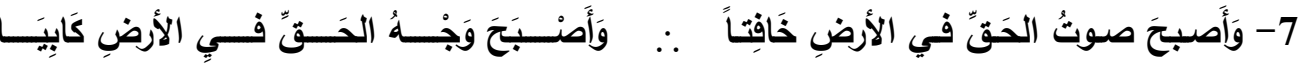

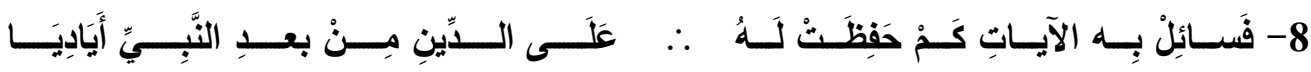

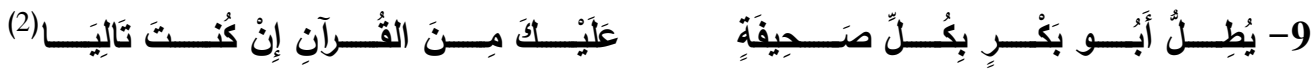

(1) ينظر: السيرة النبويـة لابن هثـام، ت / محمد بيومي (32/2)، مكتبة الإيمـان، المنصورة،

$$
\begin{aligned}
& \text { ط1، 1416هـ - 1995م. } \\
& \text { (2) الديوان (304/2، 305). }
\end{aligned}
$$


وقد حفلت هذه الأبيات بالعديد من الألوان البلاغية ومن بينها الكناية، ففي البيت الثالث بطالعنا قوله:

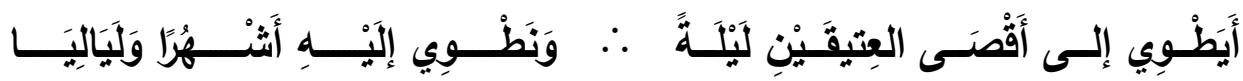

فقوله: "أبطوي إلى أقصى العتيقين ليلة" يتضمن كنايتين:

الأولى: كناية عن صفة، وهذه نستتجها من خلال التركيب كله حيث إنه دال على صفة السرعة.

وورود هذه الكناية تدليل منهم على شدة إنكارهم للإسراء. والمعنى الحقيقي لهذه الكناية مقصود بجانب المعنى الكنائي كما هو واضح. وهي كناية قريبة لا تحتاج وسائط في الانتقال من المعنى الحقيقي إلى المعنى الكنائي حيث ينتقل الذهن مباشرة من خلال التركيب إلى السرعة دون الحاجة إلى إلى وسائط.

ولتأكيد إنكارهم للإسراء يأني الثاعر بهذه الكناية في سياق أسلوب الاستفهام الإنكاري الماثل في "أيطوي" الذي يدل على شدة إنكارهم واستغرابهم لما يخبرهم به ليه

الثانية: الكناية عن موصوف وذللك في قوله: "أقصى العتيقين" كناية عن بيت 


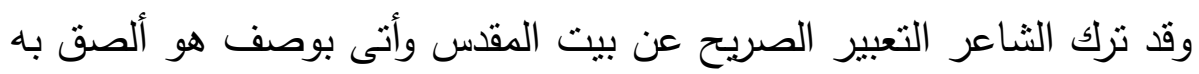

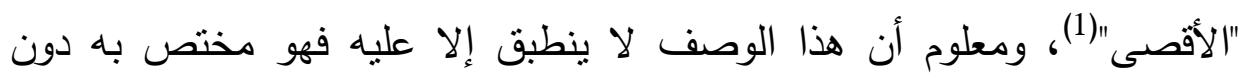
غيره من المساجد.

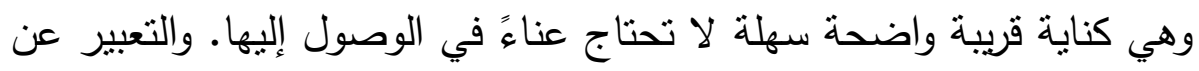

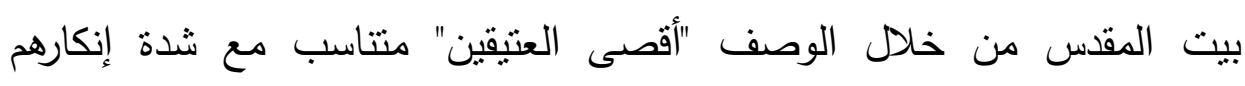

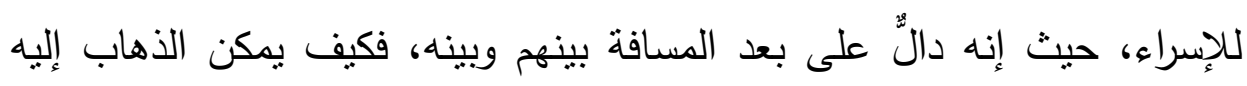

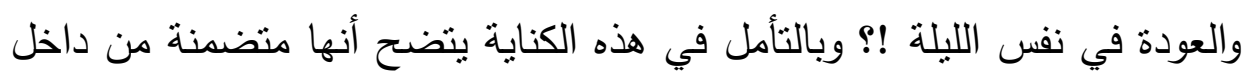

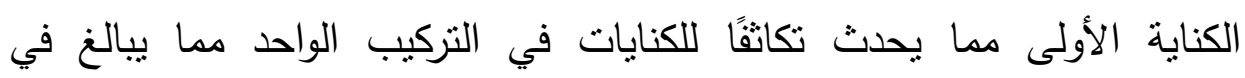
التصوير وتقرير المعنى، ويدل من ناحية أخرى على شاعرية فذة، ومقدرة فائقة على دمج الكنايات للنهوض بأعباء المعنى على أكمل وجهاه.

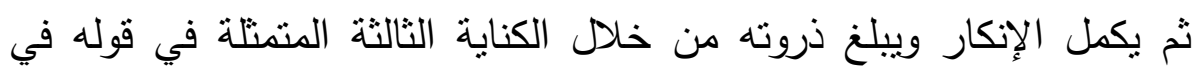

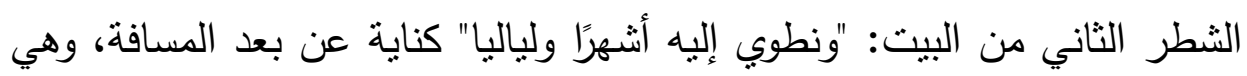
كناية قريبة أيضًا.

وإيثار الكناية على الحقيقة متتاسب مع إنكارهم، حيث إن هذه الكناية جاءت

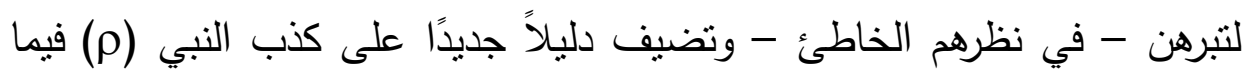

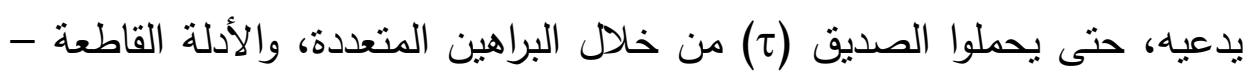

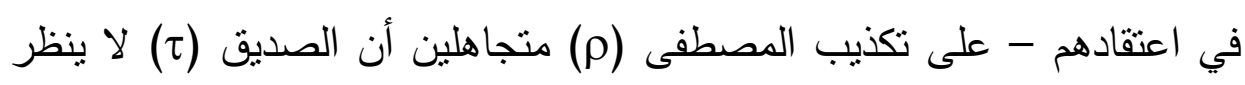

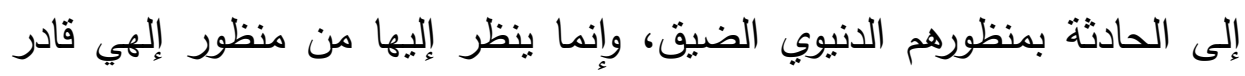

(1) ومعلوم أن وصف بيت الكقس بالوصف "الأقصى" قد استعله القرآن الكريم في الحديث عن نفس القصة في الآية الأولى من سورة الإسراء. 
قاهر، ولن يزيده ذللك إلا إيمانًا ورسوخًا وتصديقًا. فالكنايات المتوالية في البيت

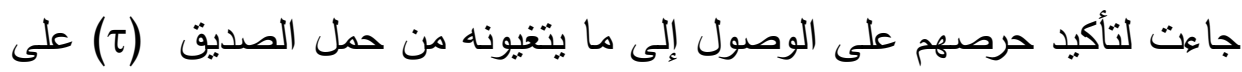
الانضمام إليهم في التكذيب.

وبمعاودة التأمل في هذا البيت - موضع الكنايات - يتضح جليًا مدى الملاعمة والتتاسق بينه وبين ما قبله وما بعده من أبيات في تخييل إنكارهم، فالبيت الأول

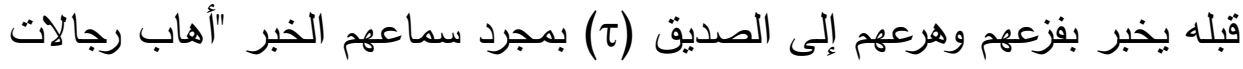
به يوم نبئوا" وللمتلقي أن يلمح براعة الثاعر في التعبير بلفظ "رجالات" وهو وإن

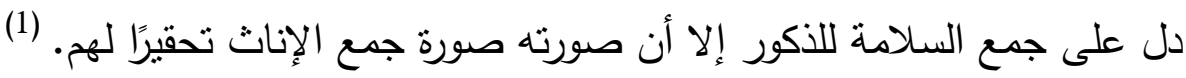
ثم قولهم للصديق (ح) في هذا الأسلوب الاستفهامي الهازئ ألم تتظر نبيك ساريا ؟ وإيثارهم التعبير بالفعل "تتظر" دون ترى الذي بمرادفه وذلك لأن النظر :

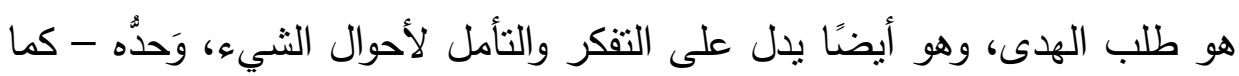
ذكر العسكريّ -. (طلب إدراك الثيء من جهة البصر أو الفكر، ويحتاج في إدراك المعنى إلى الأمرين جميعًا بخلاف الروئية فهي إدراك المرئي). (2) وكأنهم بذللك يطلبون من الصديق (ح) ألا يتعجل في التصديق، ثم إضافتهم

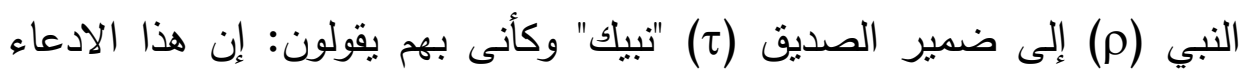
سيجعل كل من آمن به يكذبه، وينكص عن دعوته، فإن حصل منك تصديق فستكون وحدك الذي تؤمن به.

(1) ومما يقوي ما ذكرته أن هذا اللفظ وإن دلَّ على جمع السلامة إلا أن القرآن لم يستعمله.

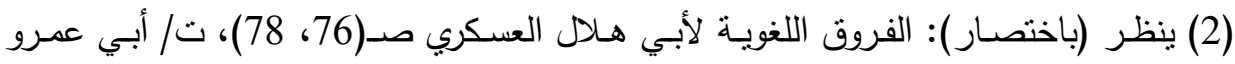
عماد ذكي البارون، المكتبة النوفيقية. 
وفي البيت التالي يكملون فصول ما حدث في هذه الدعوى من خلال ذكر

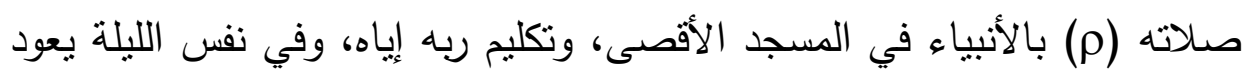

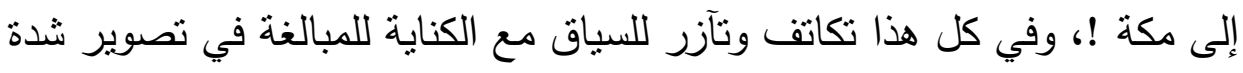
إنكارهم للإِسراء ليحملوا الصديق (ح) على التكذيب أيضًا حتى تتحطم الدعوة.

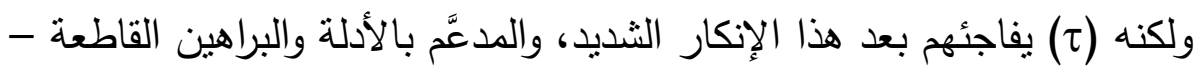

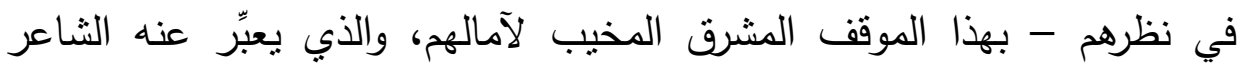
قائلاً:

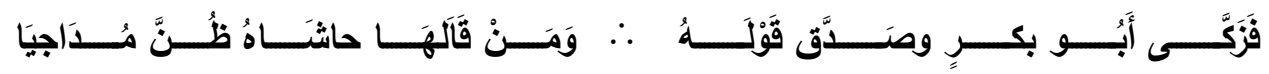

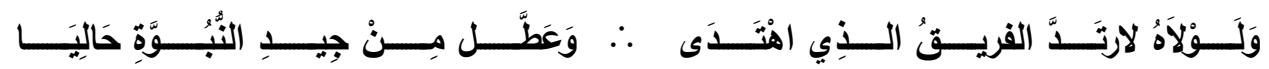

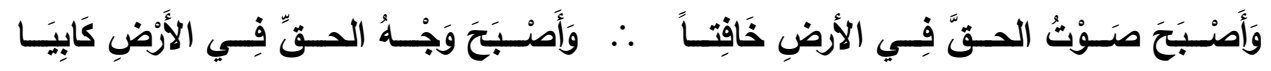

وللمتلقي أن يلحظ هذه الفاء التعقيبية الففتتح بها الأبيات "فزكى" التي تدل على الهى

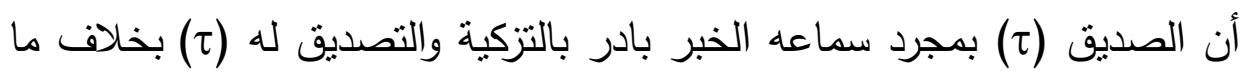

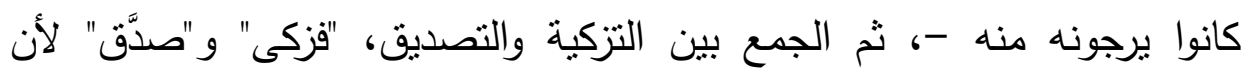

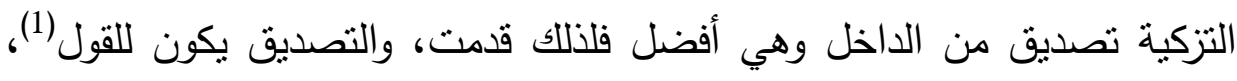

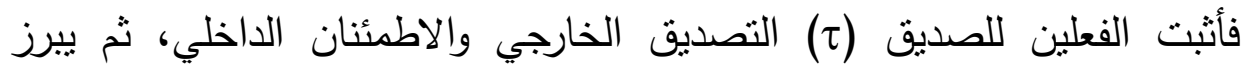
الثاعر في البيتين التاليين أثنر تصديق أبي بكر (ح) في تنبيت إيمان الدهندين،

ينظر : فروق اللغات في التمييز بين مفاد الكلمات - نور الدين بن نعمة اله الحسيني

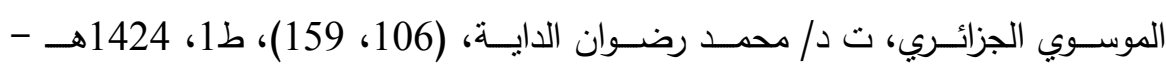
.2003 
ومساندة الدعوة، إذ لولا هذا الموقف الداعم القوي من أبي بكر لارتد المهتدون، وتعطلت النبوة وضعف أمر الدولة الإسلامية الوليدة، وآذنت بالانهزام. وقد اثتمل آخر الأبيات الثلاثة السابقة على موطنين للكناية عن صفة هما: قوله: "وأصبح صوت الحق في الأرض خافتا" كناية عن الضعف، وقوله: "وأصبح وجه الحق في الأرض كابيا" كناية عن الهزيمة. وهما كنايتان متقاربتان كما هو اهو واضح. وقد نشرت الكناية ظلالها على البيت كله لتصور لنا تصويرًا دقيقًا صورة الضعف التي كان سيمنى بها الإسلام لو لم يكن من الصديق (ح) هذا الموقف. وآثز الثاعر الكناية على الحقيقة ليقدم لنا المعنى مصحوبًا بأدلته، مقرونًا ببراهينه.

وضاعف من جمال الكنايتين اتثاحهما بوشاح المجاز المانل في الاستعارة القائمة على تشخيص الحق وإثبات الصوت والوجه لله وهو مما يبالغ في قيمة الكناية، ويؤكد قوة التصوير مما يعود على المعنى بالقوة. وقد أطلعتنا هاتان الكنايتان المتعانقتان مع الاستعارة على أثز هذا الموقف الرائد للصديق (ح) في مساندة الدعوة، وإعلاء شأنها وجليل ما قدمه لها في أسلوب رائق، ومعانٍ رائعة.

ولذلك يختتم الثاعر الأبيات التي تجسد موقف الصديق (ح) في قضية الإسراء بييتين يدلان على ما للصديق (ح) من آثار طيبة، وأياد بيضاء على الدعوة الإسلامية قبل وبعد وفاة النبي (م) فقد كانت له مواقفه القوية المشرفة، فقد كان بحق الرجل الثاني بعد النبي (م) حتى إنك لو طالعت القرآن الكريم لوجدت في

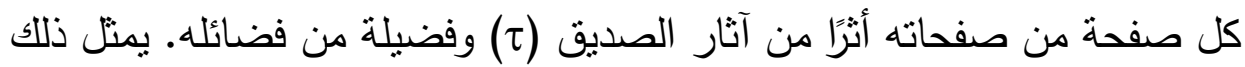

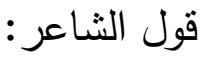




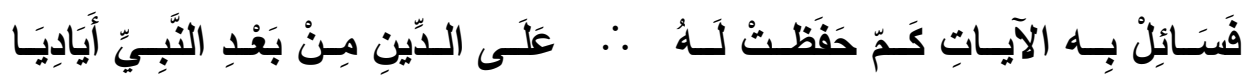

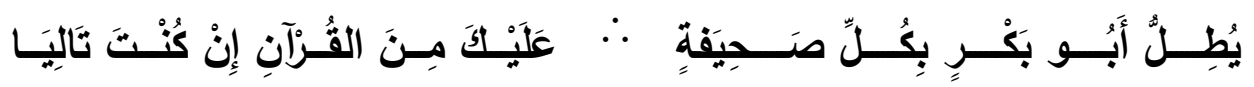

ومجموع البيت الأخير كناية عن كثرة فضائل الصديق (ح) وتعدد أياديه

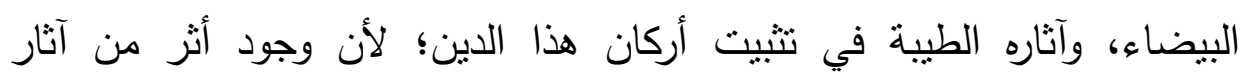

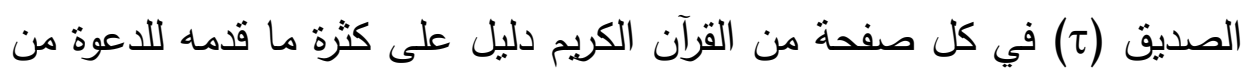
تضحيات ومساعدات وهذا بدوره يدل على كثرة فضائله وآثاره الطيبة. وهي كناية عن صفة بعيدة كما ترى لكنها لا تحتاج إلى عناء في استخراجها، كما أنها أيضًا كناية مركبة استغرقت البيت كله استغراق فضائل أبي بكر ومساندته الدعوة في كل مواققها. وتبدو روعة الكناية وجمالها وقوة ثأثيرها في تصويرها المعنى العقلي المجرد

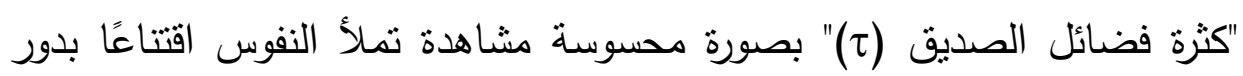
الصديق (ح) في مساندة الدعوة حين نجد في كل صفحة من القرآن الكريم أنثرًا دالاً عليه، ونشاهد في كل موقق مندوحة له.

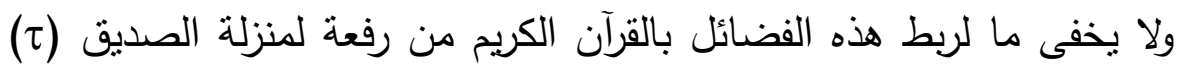
وإعلاعٍ لقدره. وقد آنز الثاعر الكناية على الحقيقة ليقام لنا الدعوى متبوعة بأدلتها مما يجعلها تستقر في النفوس، وترسخ في الأذهان. 


\section{الكناية في تصوير موقفه مع بلال بن رباح}

كما وقف الصديق (ح) بحلو كلامه، وفصاحة لسانه بجانب الدعوة ومساندتها وقف كذلك بماله في مساندة المستضعفين الذين دخل الإيمان قلوبهم ولم يسنطيعوا أن يدفعوا عن أنفسهم الأذى تجاه جبروت الطاغين وكان من هؤلاء المستضعفين الذين ذاقوا مرارة التعذيب الصحابي الجليل بلد بن رباح الذي كان مملوكًا لأحد

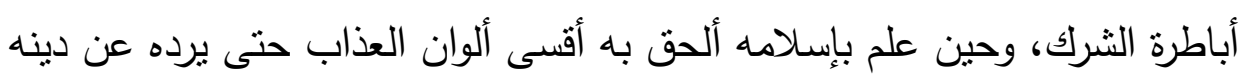
حتى إنه كان يلقيه في وقت الهاجرة على بطحاء مكة عريانًا، ثم يأمر بالصخرة العظيمة فتوضع على صدره حتى يرده عن دينه، ولكن هذا لم يزد بلالاً إلا بلاء تماسكًا، وصلابة، ولما رأى أبو بكر ما عليه بلال أعطى سيده غلامًا أسود مشركًا

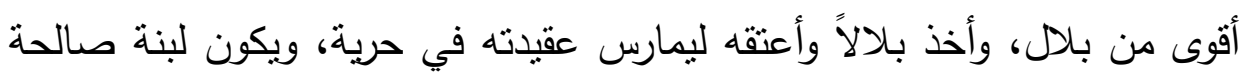

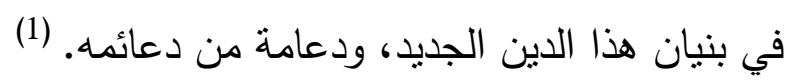
يُصَوِّر الثاعر هذا الموقف النبيل قائلاً:

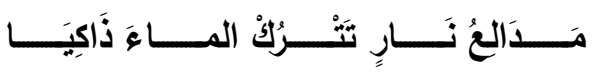

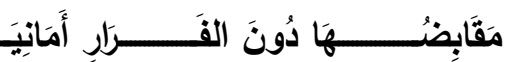

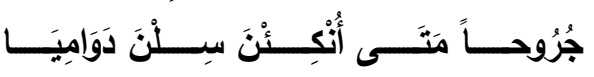

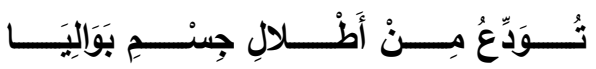

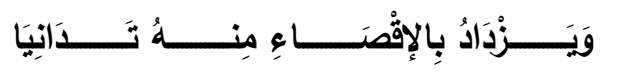

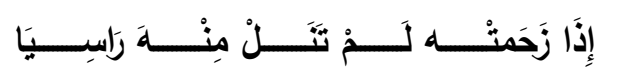

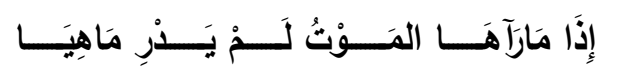

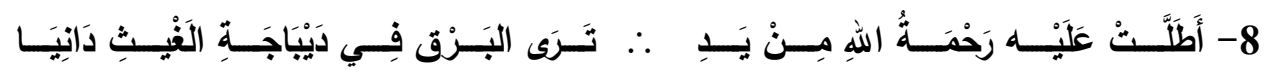

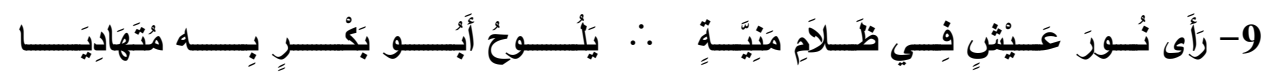
(1) ينظر : السيرة النبوية لابن هشام (198/1، 199). 


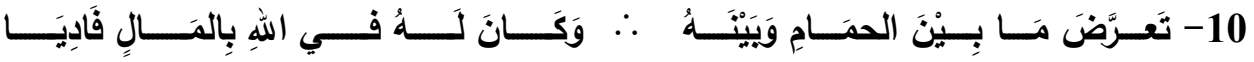

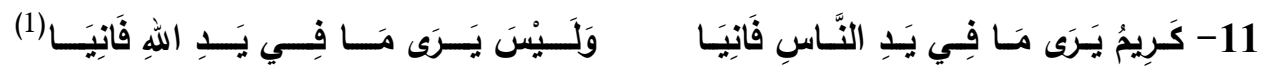

وقد تألقت الكناية ضمن ما جاء في الأبيات من ألوان بلاغية أخرى لتصور هذا الموقف الباكي مع هذا الصحابي الجليل بلال بن رباح ثم إدراك العناية الإلهية له حين قيَّض الله له الصديق (ح) ليفتديه ويعتقه خير تصوير . ففي البيت الثاني يطالعنا قوله مصورًا السياط التي يضرب بها بلال:

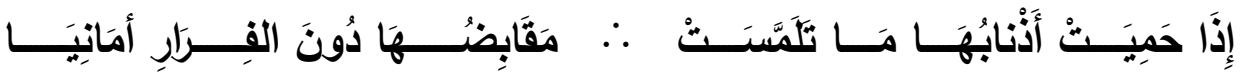

وقوله "إذا حميت أذنابها" كناية عن قسوة التعذيب، لأن حمى أذناب السياط يستلزم كثرة الضرب بها، وكثرة الضرب تستلزم شدة تعذيب من يُضرب، وهذا المعنى هو ما ترنو إليه عين الثاعر . وهي كناية عن صفة بعيدة كما هو ظاهر .

والمعنى المكني به هنا مقصود مع المعنى المكني عنه وذللك مما يبالغ في التصوير وإثبات المعنى.

وآثز الثناعر الكناية على الحقيقة هنا لينقل لنا قسوة تعذيب بلال مقرونة بدليلها وهذا أقوى وأبلغ في إثبات القسوة، يقول الثيخ عبد القاهر : "أما الكناية فإن السبب في أن كان للإثبات بها مزية لا تكون للتصريح أن كل عاقل يعلم إذا رجع إلى (1) الديوان: (305/2، 306)، مدالع النـار : مصـادرها، أنكئن: قُشْتِرنَ، اللسـان (نكأ)، الحمام: الموت. 
نفسه أن إثبات الصفة بإثبات دليلها، وإيجابها بما هو شاهد في وجودها آكد وأبلغ

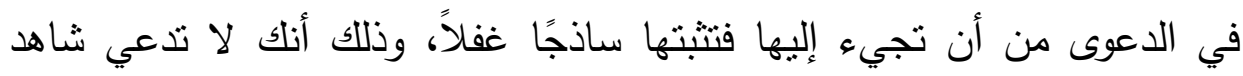

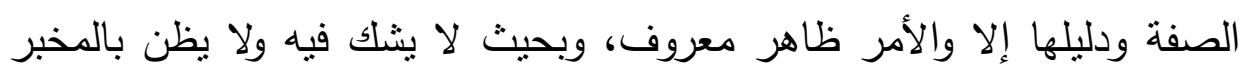

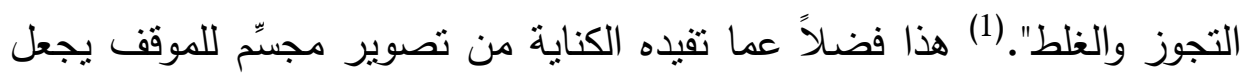
المتلقي وكأنه يشاهده فيكون إدراكه له أقوى.

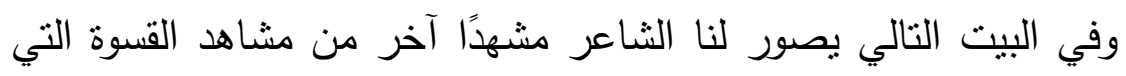

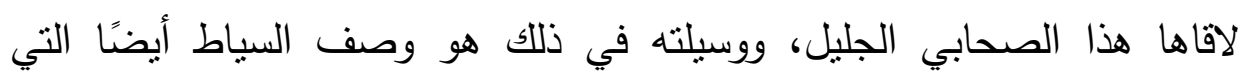
يُضرب بها بأنها تسيل بالدماء الغزيرة، يجسد ذللك قوله:

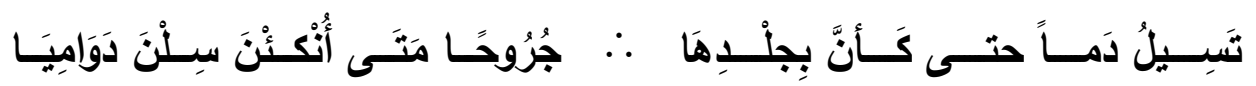

والبيت بمجموعه كناية عن قسوة التعذيب ومرارته. وهي كناية عن صفة بعيدة

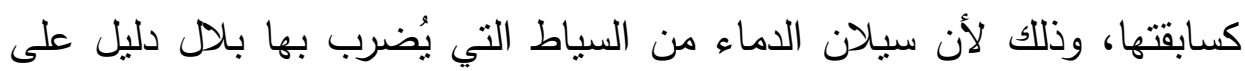
كثرة الضرب وشدته وكثرة الضرب دليل على قسوة التعذيب الذي لاقاه. وقد

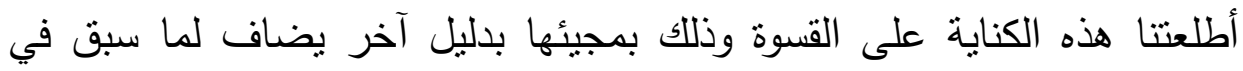

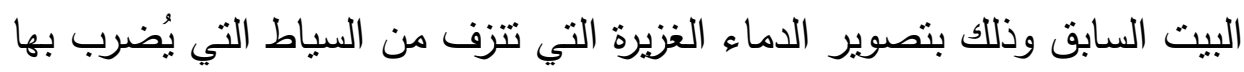

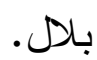

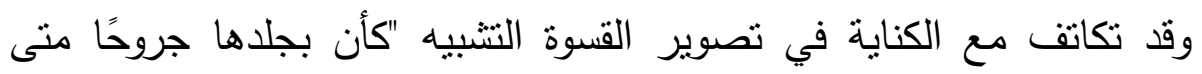

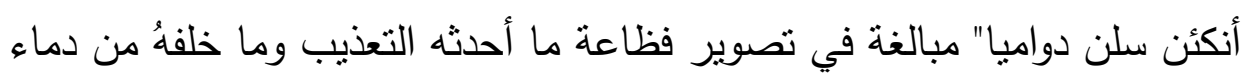

(1) - (1) دلائل الإعجاز ، ت / شاكر (72). 
غزيرة، وتبدو البراعة واضحة في التعبير بالجروح جمعًا واختيار أداة التشبيه كأن،

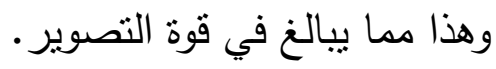

وبمعاودة التأمل في الكنايتين السابقتين نجد أن قسوة التعذيب قد كنى عنها

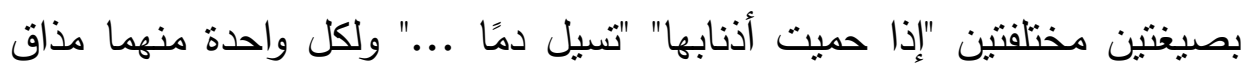

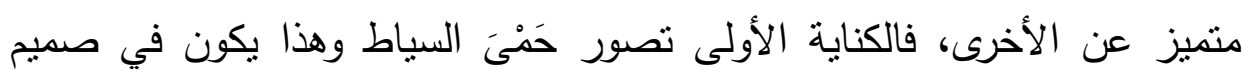

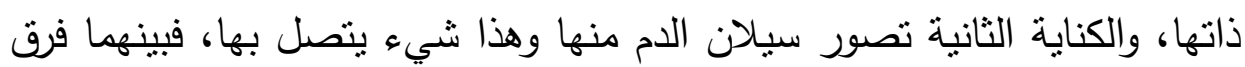
دقيق وإن كانت دلالتهما واحدة.

بعد هذا التصوير الرائع لمشاهد التعذيب تتوالى الأبيات ناقلةً لنا النتيجة

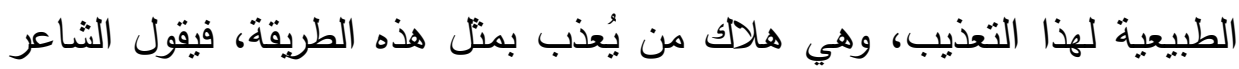
في البيت الرابع:

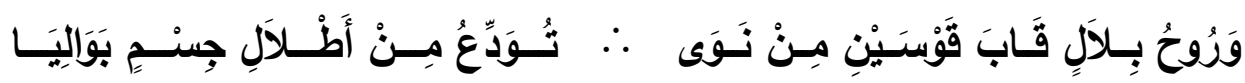

وقوله: "وروح بلال قاب قوسين من نوى" كناية عن مقاربة الهلاك فإن مقاربة فراق روح بال لجسده يستلزم قرب هلاكه.

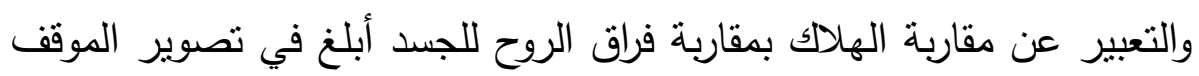
حيث يدل على أنه هلالك لا يمكن البرء منه ولا يمكن لأحد أن يدفعه عنه.

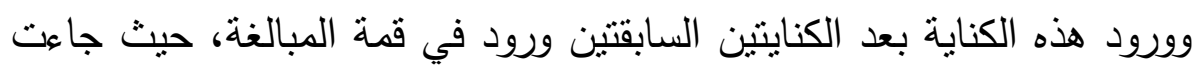

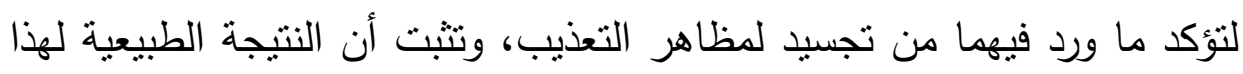

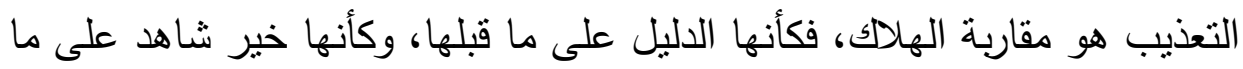

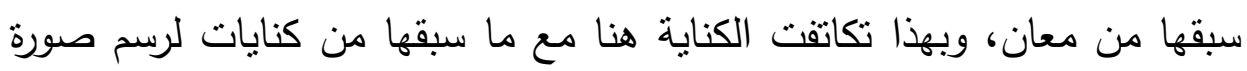


مرئية لهذا الصحابي الجليل بلال بن رباح في هذا الموقف الدحزن، وأبرزته واضحًا جليًا بأسى له كل من يطالعه.

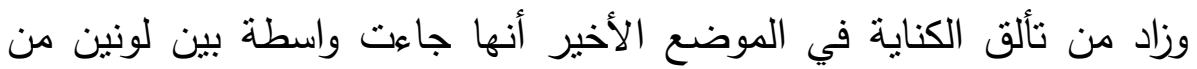

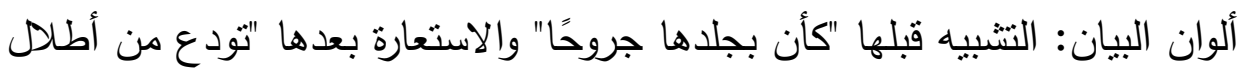

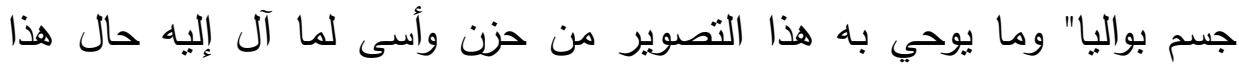
الصحابي الجليل مما يحدث نكاثفًا في التصوير يساعد على استجلاء المعنى،

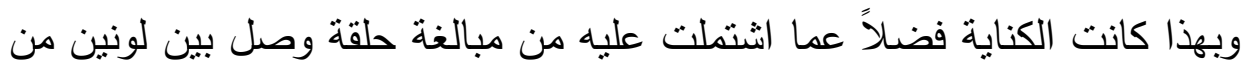

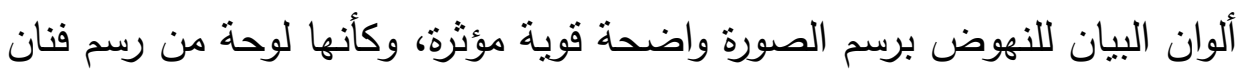
حاذق يضع كل شيء في موضعه حتى يحوز إعجاب كل من يشاهد لوحته.

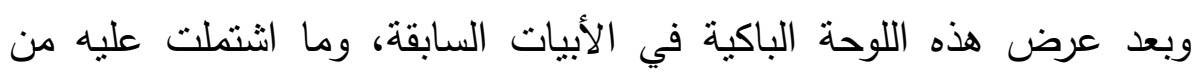
كنايات رائعة تسرد الأبيات التالية بقية أحداث هذا الموقف، وما كان من فرج بعد الائية

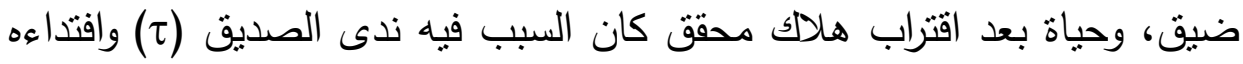

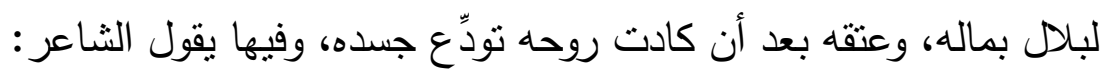

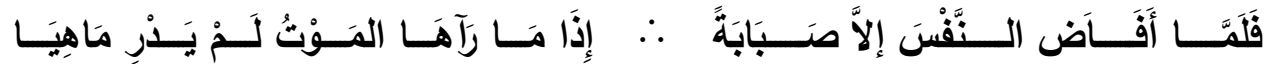

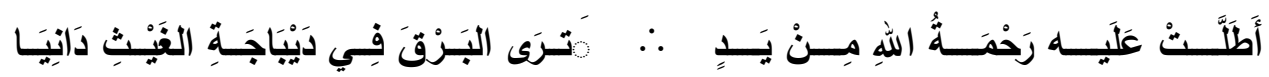

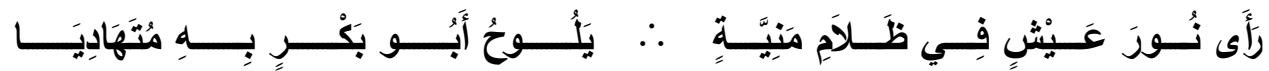

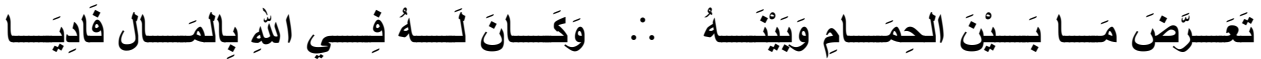

وقد اشتمل البيت الأخير منها على كناية رائعة، وذللك قوله: "تعرَّض ما بين الحمام وبينه" كناية عن تخليصه من شدته، ورفعه الظلم عنه. والمعنى الدقصود

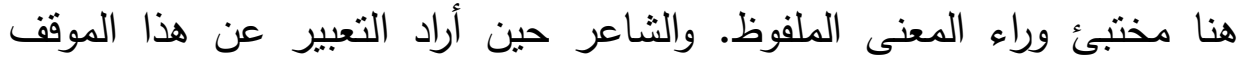
العظيم للصديق (ح) أبى له إلا أن يكون في صورة من القوة والمبالغة فأورده 
مقرونًا بدليله، مشفوعًا ببرهانه وذللك عن طريق الكناية المصورة للصديق (ح) وهو

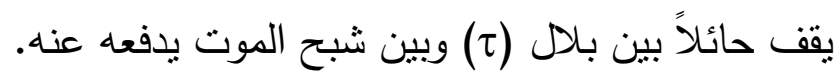

ولا شك أن التعبيرالكنائي هنا بما اشتمل عليه من تصوير رائع يفوق كثيرًا التعبير العادي الخالي عن التصوير والمبالغة. وبالغ من روعة الكناية تصويرها الثيء المعنوي "التخليص من الثدة" في صورة محسوسة مما يزبد النفوس اقتتاعًا

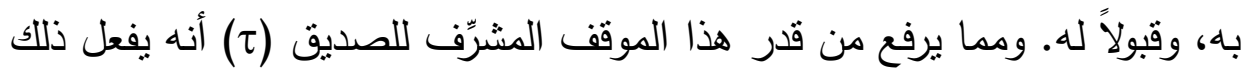
لا للرياء والسمعة، وإنما بقصد الإخلاص والتقرب إلى الله، كما يدل عليه بقية البيت والبيت بعده. وضاعف من جمال الكناية تولدها من رحم الاستعارة المصورة أيضًا التي جسمت الحمام تجسيمًا وأضحى فى مرأى العين وحثًا ينربص ببله وإذا بالصديق بحول بقدر الله بينه وبين ذلك. وبعد استعراض هذا الموقف وما اثتنمل عليه من كنايات ندرك دور الكناية الرائد في تصويرها الرائع لجوانب الموقف، وتوضيحها بأدلتها الملزمة بقبولها عن يقين واقتتاع. 


\section{الكناية في تصوير موقفه في غزوة تبوك}

من المواقف العظيمة الناطقة بجهاد الصديق (ح) وتضحيته في سبيل تثبيت أركان هذا الدين سواء كان هذا الجهاد بالمال أو بالنفس موقفه في غزوة تبوك، وكانت في السنة التاسعة من الهجرة. ومعلوم أن غزوة تبوك أو العسرة كانت لها ظروفها الخاصة، حيث كانت في وقت عسرة وجدب كما يظهر من اسمها، حتى إن الرسول (م) كان في غيرها من الغزوات إذا أراد الغزو كنَّى عما يريد إلا في غزوة العسرة فقد أخبر بها صراحة لبعد الثقة، وشدة الزمان، وكثرة العدو الذي يصمد له، ليتأهب الناس لذلك أهبته، فأمر الناس بالجهاز ، وأخبرهم أنه يريد الروم. (1) وسارع بعض الصحابة في هذه الغزوة بتقديم بعض ما يملكون للرسول (م) كي يجهز الجيش، إلا أن الصديق (ح) كان - كعادته - الفارس الذي لا يباري حيث قدم كل أمواله للرسول (م) وحين سأله الرسول (م) عما أبقى لأهله، قال في يقين ووثوق بما عند ربه: أبقيت لهم الله ورسوله. يصور شاعرنا هذا الموقف الوضئ قائلاً:

ينظر : السيرة النبوية لابن هثام (106/4)، والبداية والنهاية لإسماعيل بن كثير الدمثقي

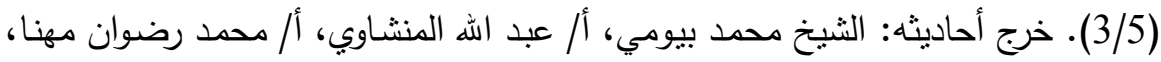
مكتبة الإيمان بالمنصورة. 


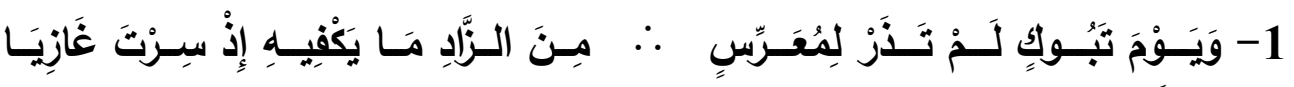

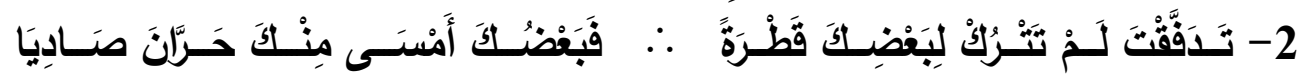

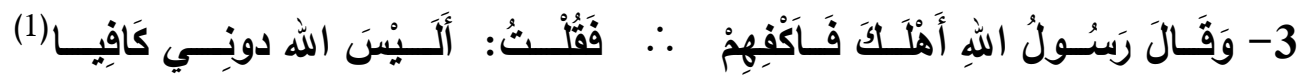
وقد حفل كل بيت من هذه الأبيات بالكناية المصورة لجوانب شتى، وأمثال

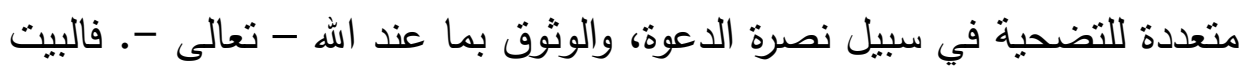

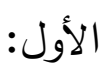

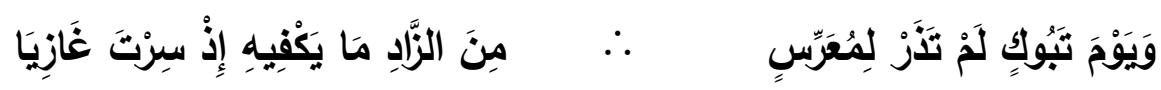
والبيت بتمامه كناية عن قوة التضحية، وكثرة ما بذله الصديق (ح) في هذه الغزوة. - مالي

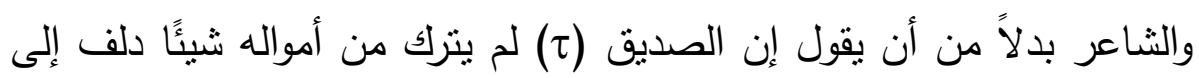

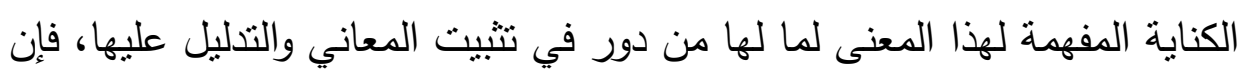
عدم تركه للمعرّّ شينًا دليل على قوة تضحيته وكثرة إنفاقه.

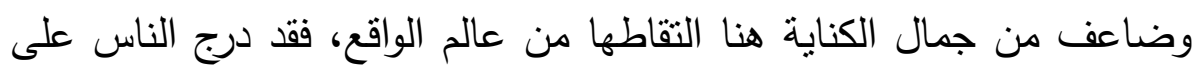

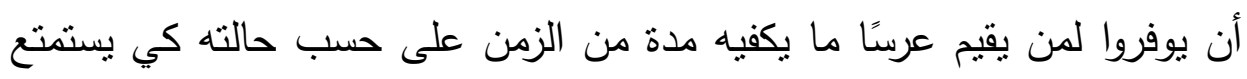

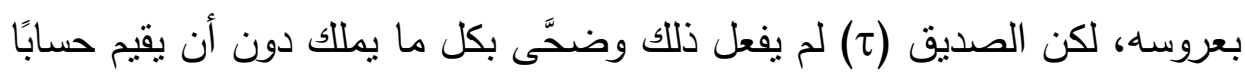
لما نعوَّد عليه الناس، وهذا دليل ساطع على قوة تضحيته، وكثرة إنفاقه.

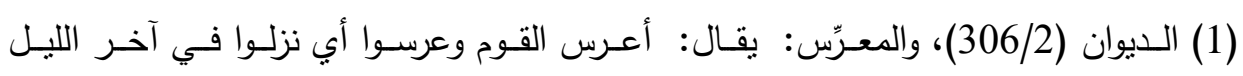
للاستراحة، هامش الديوان صد(306). 
وهي كناية عن صفة مفهومة من وراء التركيب المذكور ، وهي أيضًا كناية مركبة استغرقت البيت كله.

وفي البيت التالي يذكر الثاعر ملمحًا آخر من ملامح التضحية، وبرهانًا ثانيًا على كثرة ما جاد به الصديق (ح) في هذه الغزوة، وذللك قوله:

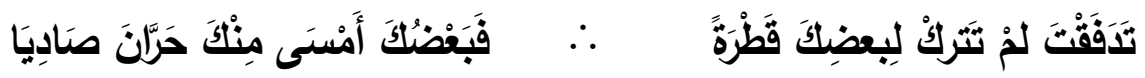
وهذا البيت ثري بكناياته، غني بكثرة دلالاته، فقد اشتمل على كنايات متعددة كلها تصب في إثبات قوة التضحية للصديق في هذه الغزوة، وكثرة ما أنفقه فيها. فقوله "تدفَّت" كناية عن كثرة الأموال التي حملها للرسول (م) ولم يقتصر جمال التصوير هنا على التصوير الكنائي، وإنما تآزر معه في إبراز المعنى وتأكيده التصوير بالاستعارة أيضًا في "تدفقت" تأكيدًا للتصوير، وإمعانًا في تجسيد كثرة العطاء، وذلك بتصوير الصديق بالبحر الواسع الكثير الماء الذي من أوصافه التذفق، وبجانب هذا التصوير الاستعاري يقف التصوير الكنائي الذي يفهم من وراء الكلام ليصور لنا كثرة هذا العطاء تصويرًا مختلفًا عن سابقه حتى تكتمل الصورة، وتتطق بالجمال، وتكون أدخل في المبالغة. ثم تتبع هذه الكناية بقوله: "لم تترك لبعضك قطرة"، وقل اشتمل هذا التركيب على نوعين مختلفين للكناية هما: قوله: "لبعضك" كناية عن موصوف، والمقصود لهرد بالبعض هنا الأولاد، فالثاعر بدلاً من أن يقول: لم تترك لأولادك قطرة ترك هذا هذابه صراحة وعدل عنه إلى قوله "لم تترك لبعضك" حيث ينتقل الذهن من البعض إلى لى

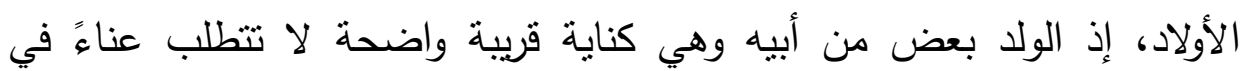
الوصول إلبها. 
والملاحظ أن المكني به (البعض) معنى واحد لا ينطبق إلا على الأولاد، والذي ساعد على تحديد دلالته هو السياق، وقد نكررت نفس الكناية في الثطر الثاني. وبالتأمل يتضح أن التكنية عن الأولاد بالبعض قد أبرز المعنى المقصود وأظهره في صورة مشرقة، فإذا كان الأولاد هم جزء من أبيهح عليه أن يوفر لهم ما باليا يحتاجونه، ويبذل كل ما في وسعه في سبيل ذلك، فإن الصديق (ح) لم يكن هذا دأبه، وإنما أخذ كل ما يملكه دون مبالاة بما يحتاج إليه أولاده - الذين هم بعضه

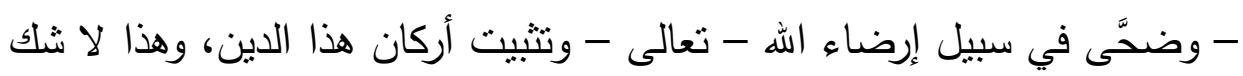
دليل قوي على قوة تضحيته، والمبالغة فيها. ثم تؤكَّد هذه الكناية بأخرى تتآزر معها، وترفع من قدرها، وذللك في قوله "قطرة" وهذه كناية أيضًا عن قوة تضحية الصديق (ح) فكونه لم ييق لأولاده من ماله شينًا ولو يسيرًا فهذا لا شك دليل قوي، وحجة دامغة في التذليل على قوة تضحيته في هذه الغزوة، وهي كناية عن صفة قريبة بسيطة كما هو واضح. وللمتلقي أن يلاحظ الفرق بين أن يقال: تدفقت لم تترك لأولادك شيئًا، وبين ما جاء عليه التركيب من التصوير الكنائي المتتابع "تدفقت لم تترك لبعضك قطرة" فسيجد أن التصوير الكنائي دال على أن الصديق (ح) لم يترك لأولاده أي شيء ولو قليل، وهذا ما لم يفده التعبير العادي، ولا يمكن له الوصول إليه، مما يجعل للتصوير الكنائي تألقًا وتأنقًا ومبالغة. ثم يختم البيت بكناية رائعة تتكاتف مع ما سبقها من كنايات لتأكيد تصوير تضحيته (ح) في هذه الغزوة، والإمعان في نقل المعنى كاملاً بأدلته، وذللك قوله "فبعضك أمسى منك حران صاديا" فقوله "حران صاديا" كناية عن قوة التضحية أيضًا، وترجع أبلغية الكناية هنا في تأكيدها لقوة التضحية مقترنة بدليلها، فمن يجود بكل ما يملك في وقت يكون أولاده في أثند الحاجة إلى ما يجود به فهذا لا لا لانها 
شك دليل قوي في إثبات قوة التضحية والمبالغة فيها، فايثار الكناية على الحقيقة هنا دليل قاطع على التضحية القوية. وذلك برسمها صورة ضوئية يتضح بها هذا

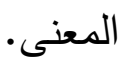

وبمعاودة التأمل في هذا التركيب الذي بنيت عليه الكناية يتضح جليًا شاعرية المصري وبراعته في اختيار الألفاظ الموحية التي تنتاغى مع الكناية وصولاً لإخراج المعنى في صورة مؤثرة، نلمح ذللك في اختياره لكلمة "البعض" وما نشتمل عليه من كناية كما سبق، ثم إضافتها إلى ضمير الصديق (ح) مما يبرز أهمية هذا البعض وأنه بمنزلة النفس، ثم اختيار الفعل "أمسى" وما يدل عليه من ظلمة حتى تتتاسب الظلمة التي تعم الأرجاء في وقت المساء مع ما هم فيه من ظلمة الحاجة، ثم التعبير بقوله "منك" الدال على أنه (ح) السبب في حاجتهم بتصدقه بكل ما يملك، وكان باستطاعته أن يكفيهم لولا خوفه من الله - تعالى - وحرصه على نشر الدعوة، ثم الختم بالوصفين المصورين موطن الكناية "حران صاديا" لكثف شدة الحاجة الني هم فيها وإظهارها واضحة جلية، وبذلك تواعمت الألفاظ مع الكناية في تتاسق معجب وتصوير خلاب مما ينعكس على المعنى بالقوة، فيزيد الإحساس بها، وتتطبع صورته في النفس.

فإذا ما تركنا هذا البيت المليء بالكنايات وذهبنا إلى البيت الأخير طالعتنا

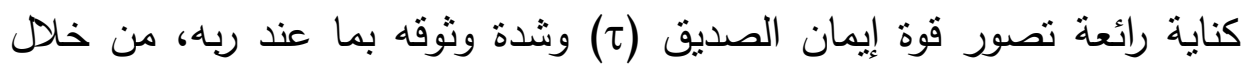
تصوير هذا الموقف الرائع بينه وبين النبي (م) حين قال له: وماذا أبقيت لأهلك يا أبا بكر ؟ فرد عليه في يقين وثبات: تركت لهم الله ورسوله. هذا المعنى هو ما نجده في البيت الأخير حيث قوله:

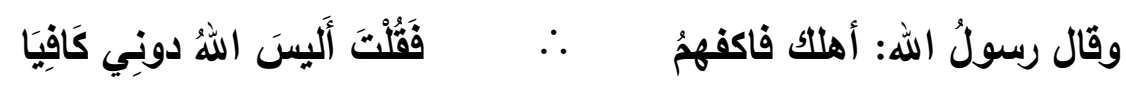


وقوله: أليس الله دوني كافيا ؟ كناية عن قوة الإيمان، وشدة الوثوق والاطمئنان

$$
\text { بما عند الله - نعالى -. }
$$

وضاعف من جمال هذه الكناية ورودها في سياق الاستفهام التقريري المثير

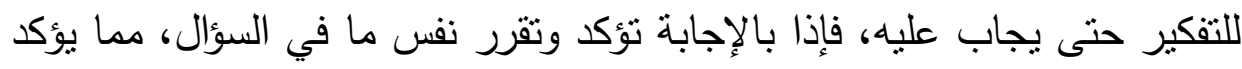

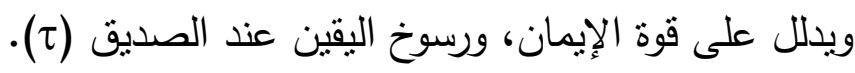

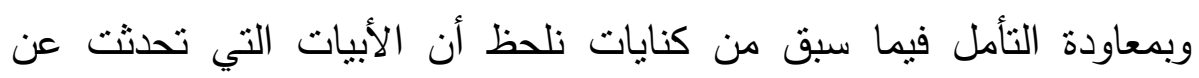

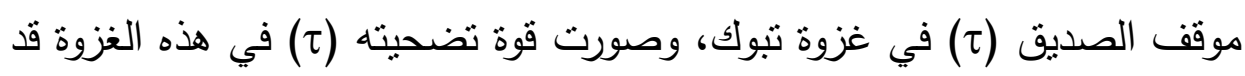

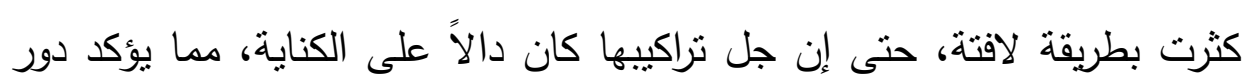

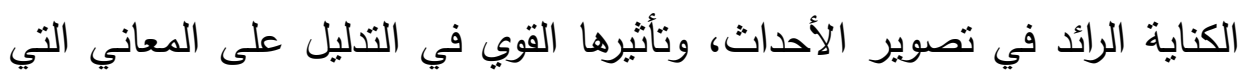
يراد إبرازها في سياق الموقف المراد، مما يجعل الثاعر يتكئ عليها اتكاءً رئيسًا، ويتخذها مطية ذلولاً للوصول لتحقيق هدفه. 


\section{الكناية في تصوير موقفه في الهجرة}

من المعلوم أنه من أهم المواقف التي تبرهن على شدة حب الصديق (ح) للنبي ( ) موقفه في الهجرة، ومصاحبته النبيَّ (م) وتضحيته بماله ونفسه وأهله. ومعلوم أيضًا أن الهجرة كانت مليئة بالخطوب والثدائد النفسية والجسدية، وهذه المواقف من الوضوح بحيث لا تحتاج إلى بيان، فهي - فضلاً عن شيوعها وشهرتها - قد سجلها الله - سبحانه - في قرآنه، وأنثى على أبطالها، وضمن لهم الحفظ والحماية والسكينة والنصر • وكان الاختباء في الغار أحد المحطات الهامة في قصة الهجرة، وكان ما حدث فيه أحد الدلائل المهمة، والقرائن القوية على شدة ولية

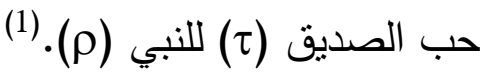
يصور الثاعر ذلك قائلاً:

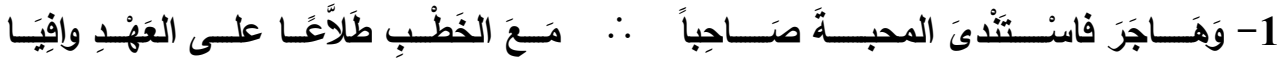

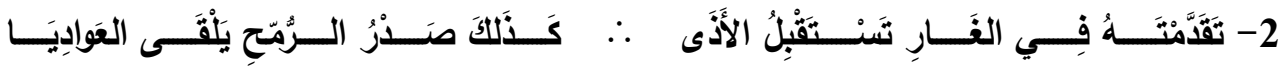

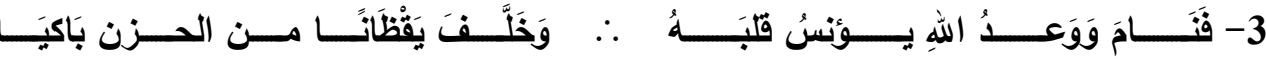

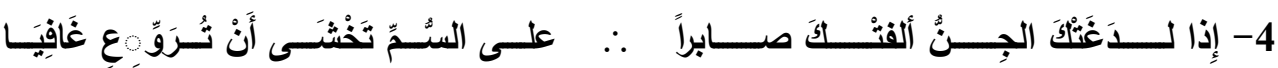

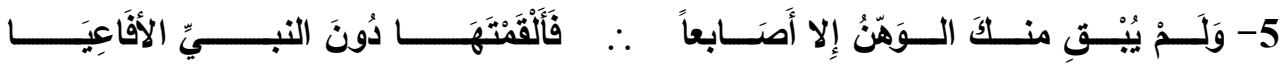

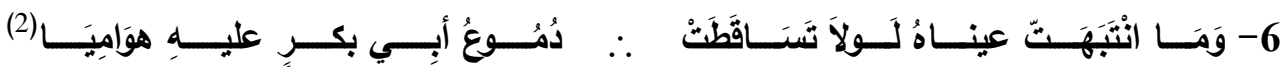

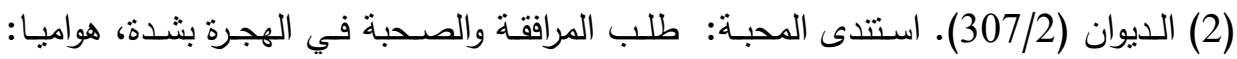
متساقطة بكثرة. 
ولا شك أن ما حدث للنبي (م) وصاحبه في الغار له دلالات كثثيرة، وجوانب

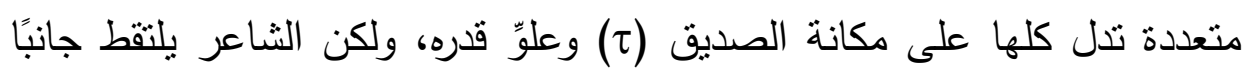
من هذه الجوانب، ويسلّط الضوء عليه، هذا الجانب هو جانب الوفاء، وشدة حب ولب الصديق للنبي (م) وقد عبر الثاعر عن وفاء الصديق، وشدة حبّه للنبي (م) من هن خلال الإتيان بمجموعة من الأدلة والبراهين المصورة لبعض المشاهد التي حدثت في الغار والتي كانت الكناية هي السبيل لإثباتها. فالاليل الأول قوله في البيت الثاني "تقدمته في الغار تستقبل الأذى" وهذا كناية عن شدة حب الصديق للنبي (م) فإن من يتقدم إنسانًا في موقف يحتمل فيه أذاه يستلزم شدة حبه ووفائه له، وهذا دليل ساطع، وبرهان قوي مصور لثدة الحب، ولذلك آثر الثاعر الكناية على الحقيقة ليعرض المعنى مقرونًا بدليله فيكون أقوى في إثباته، وأثثد تأثيرًا في النفس، يقول الإمام عبد القاهر: "إذا قلت: "هو كثير رماد القدر" كان له موقع وحظ من القبول لا يكون إذا قلت: "هو كثير القرى

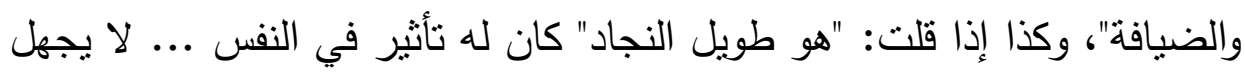

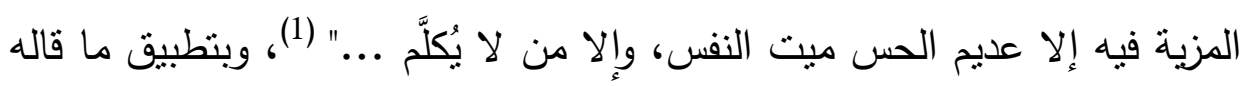
الإمام على المثال الذي معنا يظهر لنا صحة ما قاله والوثثق بهه، فإن من يثاهد تقدم أبي بكر على النبي (م) من خلال التعبير الكنائي يتيقن بشدة حبه له، وخوفه عليه، ويعتقد ذلك بما لا بدع مجالاً للشك. للك. وضاعف من جمال الكناية ترشيحها بالتشبيه بعدها في قوله "كذلك صدر

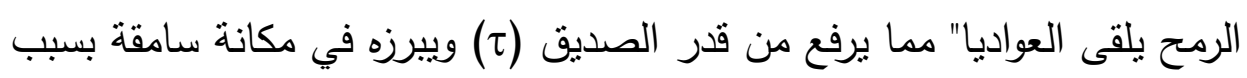
شدة حبه للنبي (م). (1) دلائل الإعجاز، ت / شاكر (430). 
الاليل الثاني: وقد تضمن هذا الدليل البيت الرابع حيث قوله:

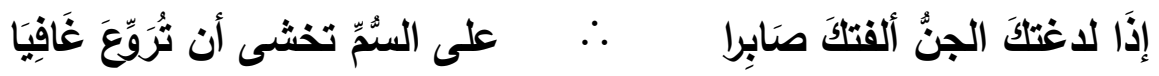
والبيث كله كناية عن شدة حب الصديق للنبي (م) ووفائه له، فإن من يصبر على ما يفتك بحياته خوفًا من ترويع إنسان آخر لأصدق دليل وأوضح برهان على ألى شدة حبه له، وخوفه من أن يناله أي أذى. له. وكما تقوَّت الكناية السابقة بالتشبيه، تقوت هذه الكناية بالاستعارة التصريحية المتمثلة في قوله "إذا لاغتلك الجن" وذلك باستعارة الجن للأفعى القوية الفاتكة مبالغة في شدة اللاغ، وإمعانًا في التصوير وصولاً إلى إبراز جمال الكناية وتقوبتها. الاليل الثالث: ويتضمنه البيت الخامس وهو قوله:

ولم يُبْق منتكَ الوهنُ إلا أَصَابِعاً فقوله "فألقمها دون النبي الأفاعيا" كناية عن شدة الحب والوفاء وهذه أيضًا بيّنة صادقة تضاف لما سبق تأكيدًا لثدة الحب الذي يكنه الصديق للنبي (م). ولنا أن نلحظ التعبير بالجمع "الأفاعي" الذي بدل على أنها مخاطر كثيرة مهلكة ومع هذا بتصدى لها الصديق (ح) ويضحي بنفسه حتى لا يلحق الرسول (م) أي أذى وهذا مما يبالغ في شدة حبه له، وهذا مما يحدث تكاتفًا بين النظم

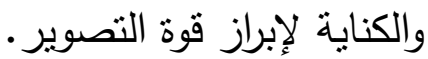
وبالتأمل يتبين أنه كما اتكأت الكناية السابقة - في البيت الرابع - على الاستعارة "الدغتك الجن" للإمعان في قوة التصوير اتكأت هذه الكناية على كناية أخرى ترفع من قدرها وتعلي شأنها، وذلك في الشطر الأول من البيت حيث قوله: "ولم ييق منك الوهن إلا أصابعا" فهي كناية كاثفة عن شدة التعب، وقوة الإعياء 
الذي لحق بالصديق (ح) في الهجرة وصولاً لما تضمنته الكناية في الثطر الثاني

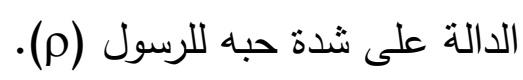

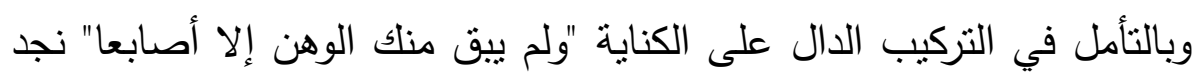

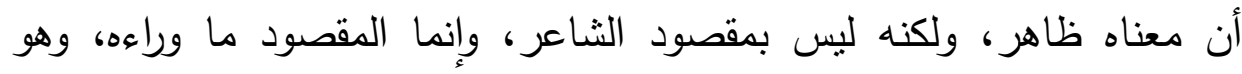
الكثف عن شدة التعب الذي حل بالصديق (ح) ليكون ذلك دليلاً ساطعًا، وبيِّنة صادقة على شدة حبه للنبي (م). وبمعاودة التأمل فيما سبق من كنايات يتبين لنا كيف أن الكناية قد نقلت لنا

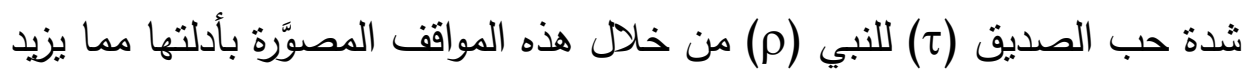

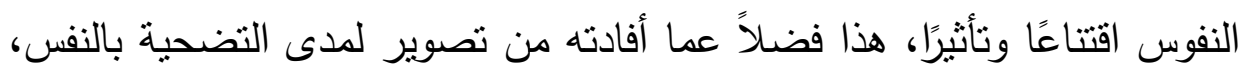
والذي ضرب الصديق أروع أمثلنها.

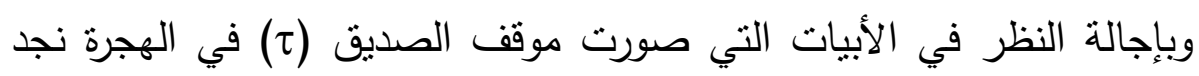

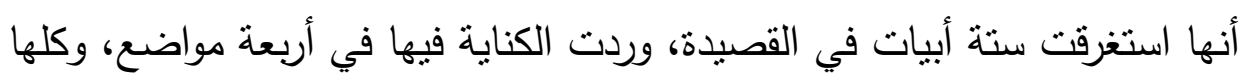

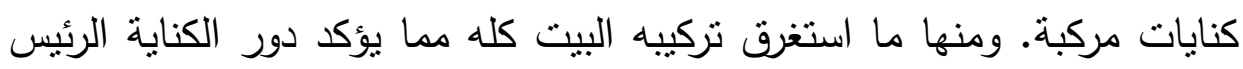
في التصوير، ويقرر دورها الفاعل فيه، مما جعل الثاعر يعتمد عليها الثيها اعتمادًا

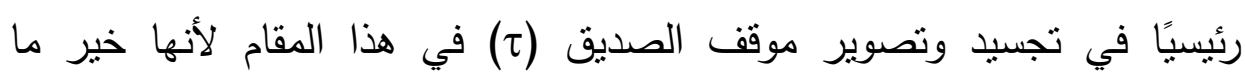
يساعده في تصوير معانيه في صورة رائقة تقنع النفوس، وتمتع العقول. 


\section{الكناية في تصوير موقفه في غزوة بلر}

لم يكن دور الصديق (ح) في نصرة الدعوة قاصرًا على إمداد المسلمين بما يحتاجون إليه من أموال، وإنما كان دوره في الجهاد بالنفس وشجاعته في منازلة

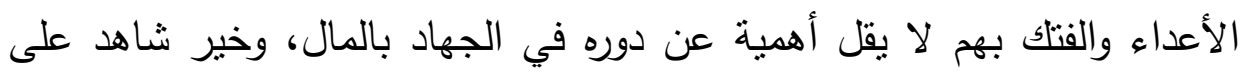
ذلك موقفه في غزوة بلر التي كانت في بداية الدعوة الإسلامية، ولمَّا يشتد ساعد

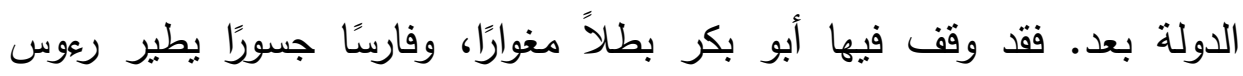
الأعداء، ويلحق بهم الهزائم فيرجعون مهزومين مقهورين، حتى بلغ الأمر أن عليًّا - كرم الله وجهه - وهو من هو في الشجاعة والقوة كان يستحيي - إذا ذكرت شجاعة أبي بكر وبسالته في هذه الغزوة - أن يُسلَّ سيفه في حضرته. يصور الثاعر هذه المعركة، وما حدث فيها من وقوف الرسول (م) حين حمى الوطيس، واثتنت المعركة مناجيًا ربه وهو في العريش الذي بناه له أصحابه،

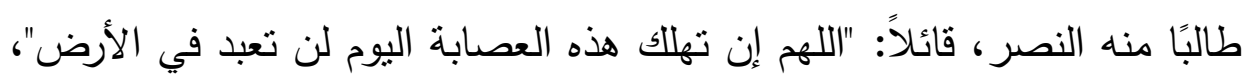

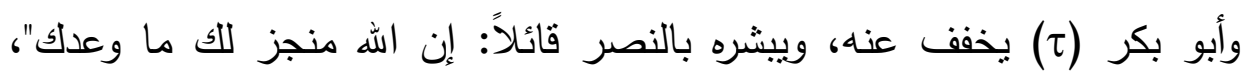
فتأخذ النبي (م) سنه من النوم ثم ينتبه قائلاً: أبشر يا أبا بكر ، أتاك نصر الله،

هذا جبريل آخذ بعنان فرس يقوده، على ثناياه النقع". (1) بسجل الثاعر كل ذللك قائلاً:

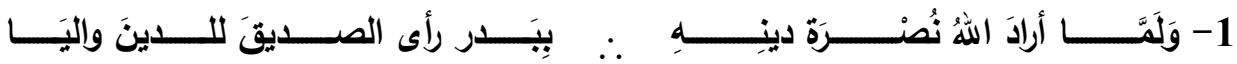

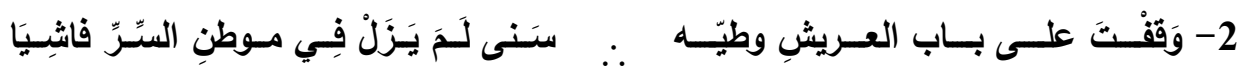

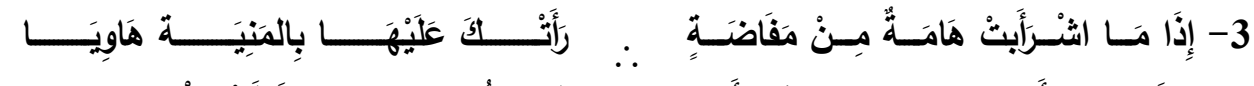

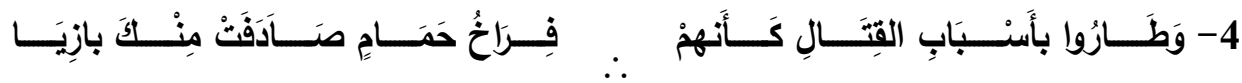




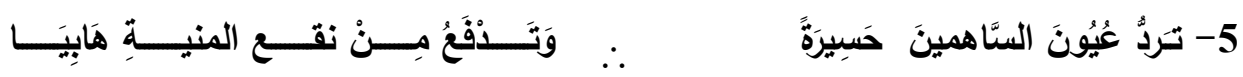

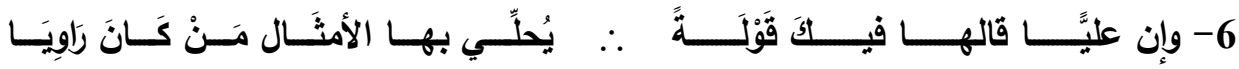

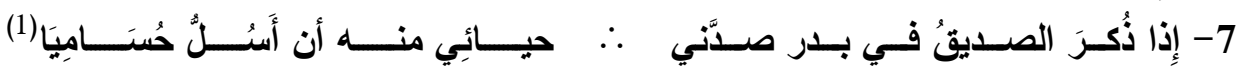

وقد استخدم الثاعر في بيانه لمواقف الصديق (ح) في هذه الغزوة جلَّ طرائق البيان وعلى رأسها الكناية، حيث وردت في عدة مواطن تدليلاً على مواقفه الناصعة الناطقة بفضله، ففي قوله في البيت الثاني:

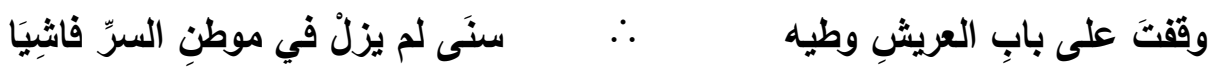
قوله "موطن السر" كناية عن موصوف هو عالم الغيب. وهذه الكناية تصور إلهام الصديق في تبشيره النبي (م) بالنصر حين رآه يناشد ربه ويسأله النصر على الأعداء، فيخاطبه الصديق (ح) قائلاً: "إن الله منجز للك ما وعدك"، وبالفعل يأتي النصر من عند الله - تعالى - كما بشر به الصديق (ح).

ولا شك أن من يخبر بشيء في عالم الغيب يكون ملهمًا. والتعبير بموطن السر بدلاً من عالم الغيب يكثف قوة خفاء النصر، وأنه لم

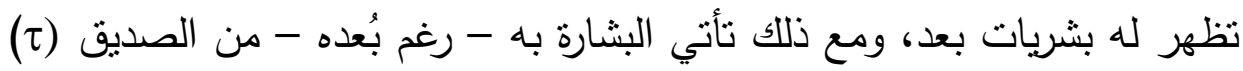

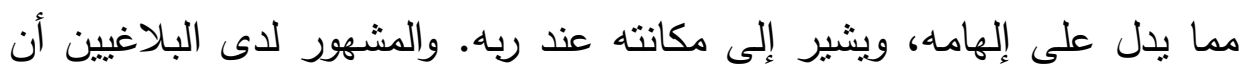
يكون موطن السر كناية عن القلب، وذلك كما عند أبي نواس في وصفه للخمر: (1) الديوان: (307/2، 308). السنا: الثـعاع من الضوء، الدفاضـة: الدروع الواسعة، البازي:

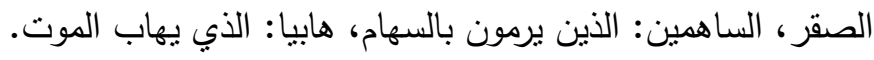




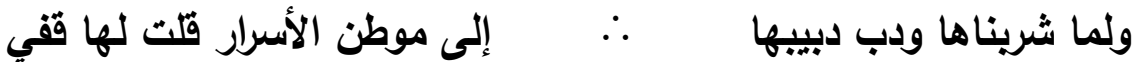

لكن السياق هنا يحدد لها معنى آخر غير المشهور هذا المعنى هو عالم الغيب، مما يبرز أثز السياق في تحديد دلالة الكناية. وبعد أن تحدث الثاعر عن جانب التبشير بالنصر وهو لا شك مطلوب في ميدان القتال، يلتقط جانبًا آخر من الجوانب الدالة على دور الصديق (ح) في تثبيت أركان الدعوة، وهو جانب القتال، ومجالدة الأعداء، يصور ذلك قوله:

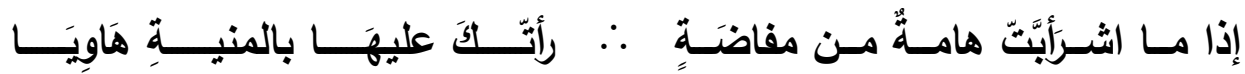

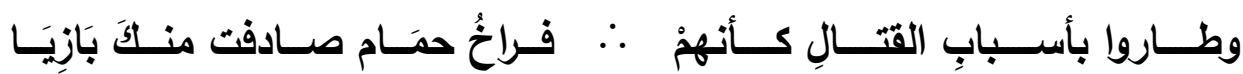

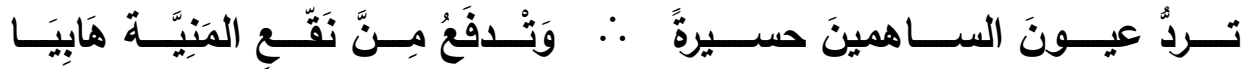

$$
\text { وقد وردت الكناية في هذه الأبيات في عدة مواطن: }
$$

في البيت الأول حيث يدل مجموعه على الكناية عن صفة الثجاعة التي

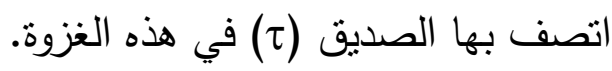
لأن من يسطو على الأعداء، ويقضي عليهم بهذه الطريقة لا شك يكون في قمة الثجاعة.

ومما بالغ في إبراز قوة الشجاعة تتكير "هامة" و "مفاضة" وتصدير البيت بإذا المفيدة تحقق وقوع ما بعدها، ثم اختيار الفعل "اثرأبت" دون نظرت لأن ما عبَّر به الثاعر دال على النظر بعناية وخوف وتطلع، ثم التعبير في الثطر الثاني بفعل الروئة "رأتكا" الذي يصور حالة الفزع التي تصيب الأعداء حين يرون

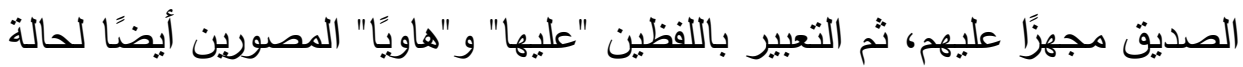
الذلة والانكسار التي تحيط بالأعداء، وأيضًا يثتنان الرفعة وعلو المنزلة للصديق هيق

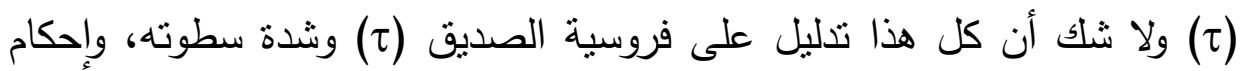


قبضته على الأعداء، مما يحدث تعاورًا لعناصر النظم مع الكناية في تصوير المعنى ونقله بكل أدلته.

وضاعف من جمال الكناية هنا إيلاؤها ببيت يشتمل على الاستعارة والتنتبيه في

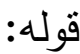

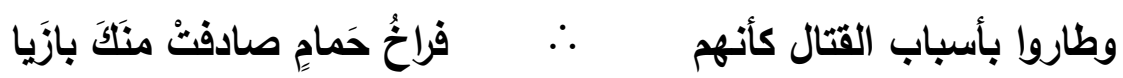

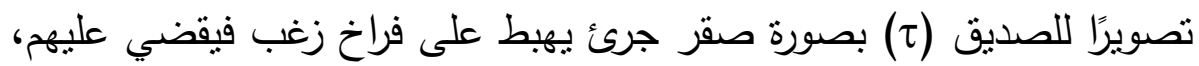

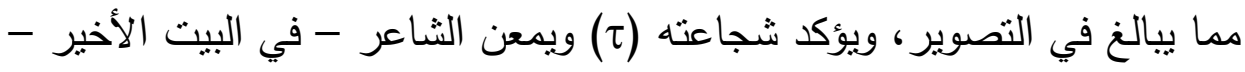

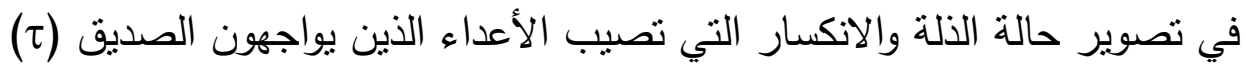
ليتوصل من خلالها إلى إثبات قوة شجاعته - فنراه يقول:

تردُ عيونَ السَّاهمِِِِنَ حَبِيرةً

وقد انتمل هذا البيت على كنايتين، فالثطر الأول: "تزد عيون الساهمين

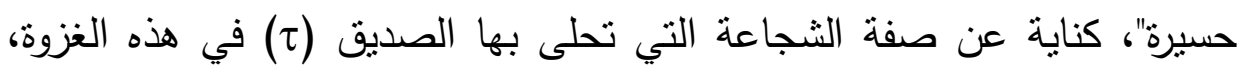

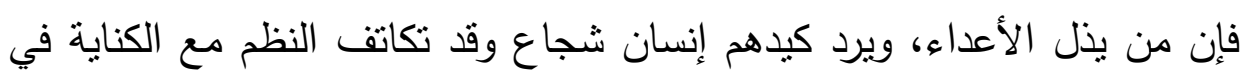

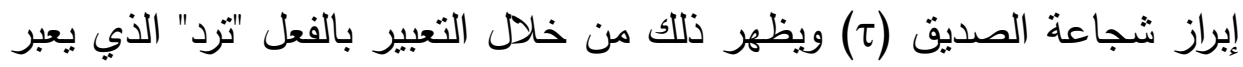

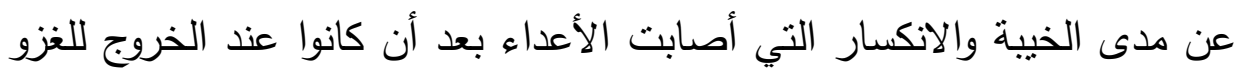

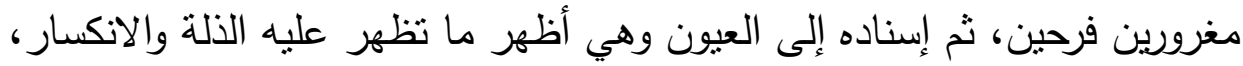

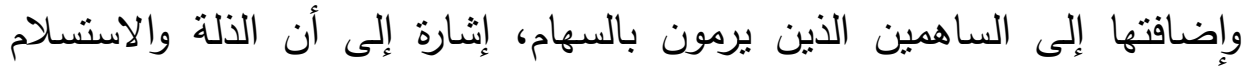

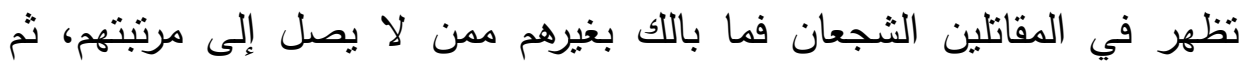

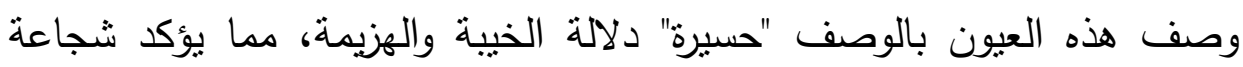
الصديق (ح) وقسوته على أعداء الدعوة.

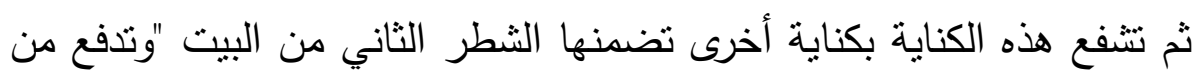

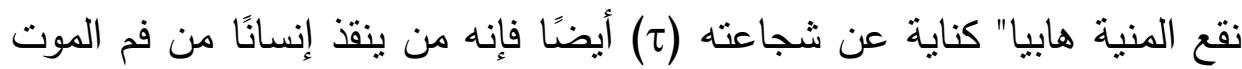

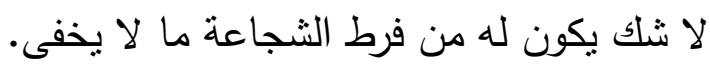


ولنا أن نتأمل الفعل "تدفع" وما يدل عليه من الحماية بقوة، ثم التعبير بنقع المنية. وما يشتمل عليه من تصوير يتآزر مع التصوير الكنائي للتأكيد على لهي شجاعة الصديق (ح) في هذه الغزوة، وإبراز دوره الرائد فيها. وبالتأمل فيما سبق من الكنايات المصورة لموقف الصديق (ح) في هذه الغزوة يتبين أن الكناية قد وردت أربع مرات وكانت كلها متوافقة مع الحديث عن الغزو، كان الموطن الأول منها "موطن السر" كناية عن عالم الغيب للتدليل على التيقن بالنصر ، وهذا لا شك مطلوب في مجال الغزو لأنه يبعث الثقة والثبات في قلوب المهاجرين فيساعد على النصر، وتحقيق الهدف، وجاءت الكنايات الثلاث الأخرى عن الثجاعة التي امتاز بها الصديق (ح) في هذه الغزوة، ولا يخفى - ما للتكنية عن الثجاعة بكنايات كثثرة من نتاسب مع سياق الحديث عن الغزو، فهو خير موقف تظهر فيه شجاعة الشجعان، ويستدل به على قوة الفرسان، مما يظهر تتاسق ما ورد من كنايات مع مقام الغزو. كما أن تعدد ورود الكناية عن صفة الثجاعة مما يؤكد أهمية الأخذ بالأسباب في سبيل تحقيق الهذف، فلم يكتف الصديق (ح) بالتيقن بالنصر لأن الله سبحانه - وعدهم به، وإنما باشر الأسباب، ووقف في ميدان القتال بطلاً مغوارًا. ومحاربًا جسورًا حتى تحقق النصر، مما يبرز دور الكناية في إبراز المعنى وإحضاره بأدلته حتى تقنع النفوس بهاه. 


\section{الكناية في تصوير موقفه من صلح الحديبية}

من المواقف الجليلة للصديق (ح) موقفه من صلح الحدييية الذي عقده الرسول (م) مع سهيل بن عمرو مبعوث قريش إليه حين خرج قاصدًا مكة للعمرة، فأغضب ذلك قريشًا، فأرسلت إليه من بستعلم سبب مجيئه، فأخبرهم أنه ما جاء إلا لزيارة البيت الحرام، فغضبوا أيضًا وقالوا: لن نسمح بأن يدخلها علينا عنوة، ويتحدث عنا العرب بذلك، فأرسل إليهم النبي (م) عثمان بن عفان (ح) فحبسته قريش، وأثنيع بين المسلمين أنه قتل، فدعا النبي (م) أصحابه إلى البيعة، فكانت بيعة الرضوان تحت الثجرة، فأرسلت قريش سهيل بن عمرو لمصالحة النبي (م)

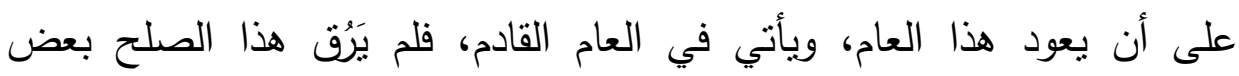
الصحابة فغضبوا، لكن الصديق (ح) استدرك الموقف، وأقنع الصحابة ببعد نظر ئرة

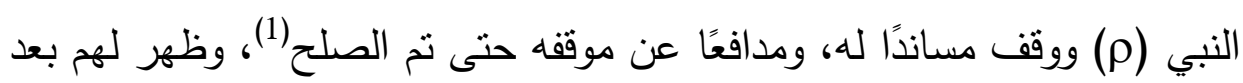
بعد ذلك رجاحة عقله ( ) وبُعد نظره.

حكى أن عمر بن الخطاب (ح) بعد أن عقد النبي (م) الصلح مـع سهيل بن عمرو جاء

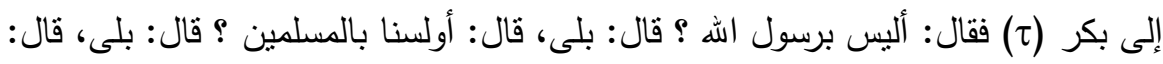

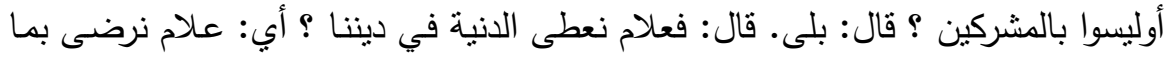

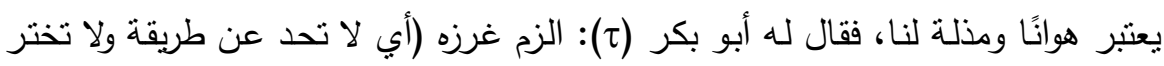

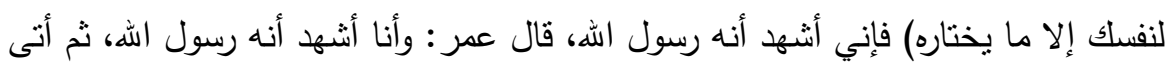

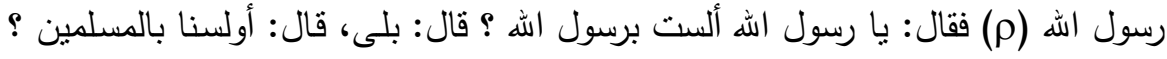

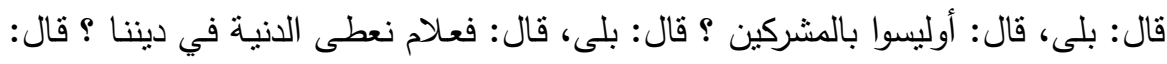

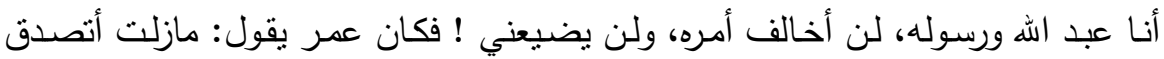

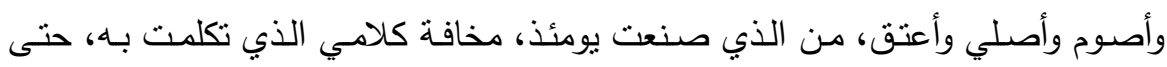
رجوت أن يكون خيرًا. ينظر : السيرة النبوية: (202/3). 
ولم ينس شاعرنا وهو يجسد مناقب الصديق (ح) أن يعرِّج على هذا الموقف

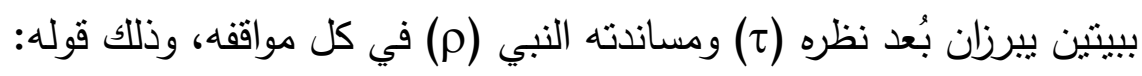

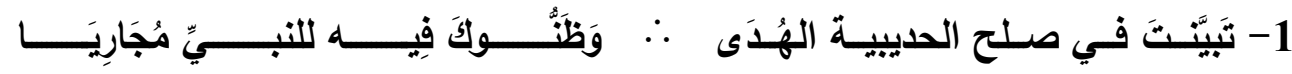

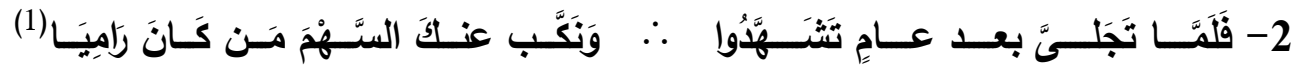
وقوله في البيت الثاني "ونكَّب عنك السهم من كان راميا" كناية عن الرجوع للحق بعد النكوص عنه. وواضتح أن ليس المغزى هنا نصوير من كان مخالفًا لأبي بكر في صورة من يدفع عنه السهام، وإنما ما وراء ذلك من رجوعهم إلى ما ارتآه، وتبينهم الحق فيه بعد تخطئنه، مما يثبت رجاحة عقله. وترجع بلاغة الكناية هنا في أنها أبرزت الثيء المعقول (الرجوع للحق بعد التمرد عليه) في صورة محسوسة، وهي صورة من يدفع السهام عن من كان يروم قتله، ولا شك أن إبراز المعقول في صورة المحسوس مما يزيد النفوس اقتتاعًا به وذلك لما للتصوير من تأثير قوي في النفوس. وهي كناية عن صفة كما هو إيران واضح، والذي حدَّد دلالتها هو السياق.

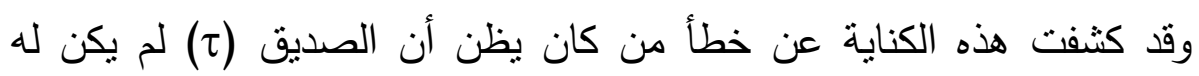
موقف من الصلح سوى أنه كان مجاريًا للنبي (م) في عقده للصلح، لكن لما

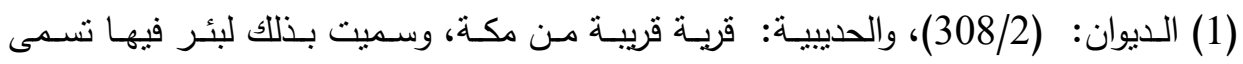
الحدييية. 


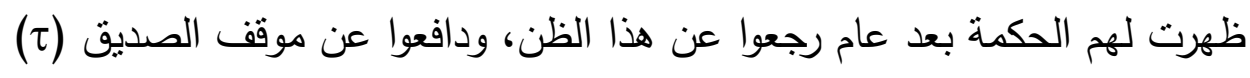
مما يؤكد رجاحة عقله (ح) وعظم مكانته.

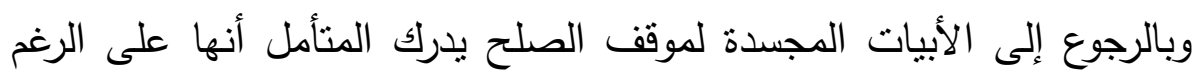

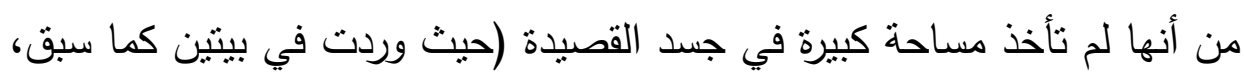

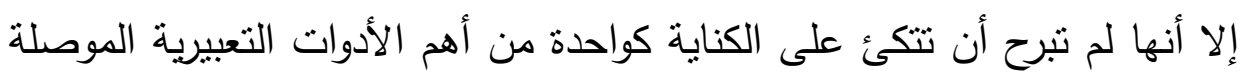

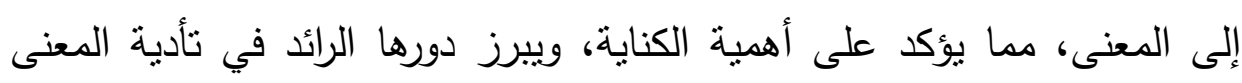

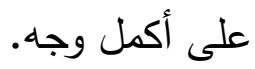




\section{الكناية في تصوير موقفه حين مرض الرسول (م)}

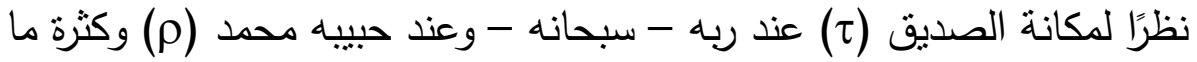
قدمه لخدمة هذه الدعوة لم يجد النبي (م) حين اثتل به المرض من هو أفضل

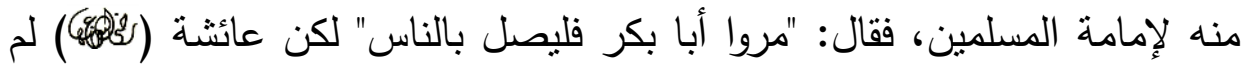
يكن يروقها هذا الاختيار لما تعلم من مكانة الرسول (م) عند أبي بكر، فقالت: يا نبي الله، إن أبا بكر رجل رقيق، ضعيف الصوت، كثير البكاء إذا قرأ القرآن، فقال (م): "مروه فليصل بالناس" فعادت عائشة بمثل قولها، فقال الرسول (م): "إنكن صواحب يوسف، فمروه فليصل بالناس"(1)، وأصرَّ النبي (م) على اختياره، وكأنه

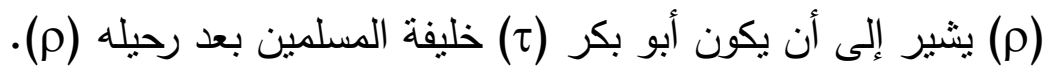
يعرض الثاعر ما حدث في هذا الموقف في تصوير رائق قائلاً:

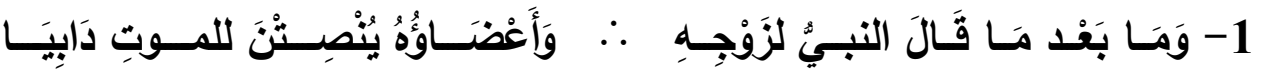

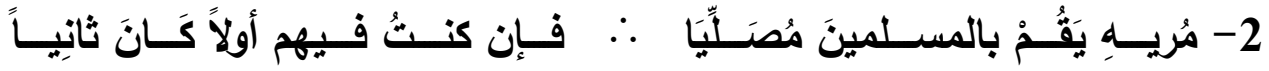

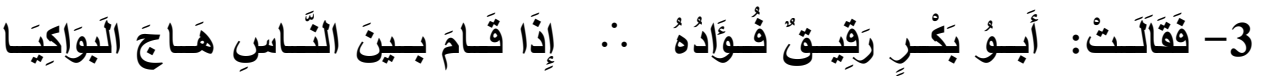

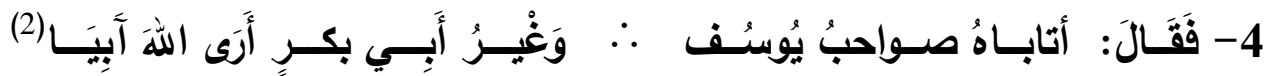
وقد احتشد شاعرنا في سبيل الكثف عما سبق من معان ألوانًا بلاغية كثيرة من بينها الكناية، ففي مطلع الأبيات يطالعنا قوله:

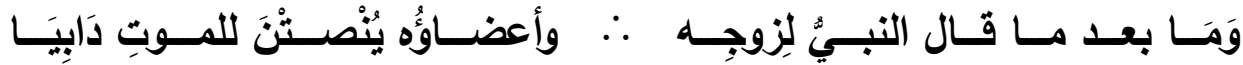

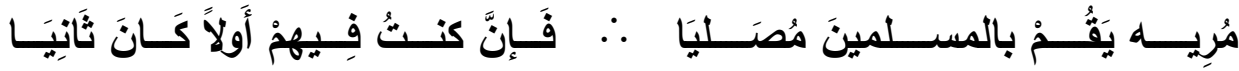


وقوله: "وأعضاؤه ينصنن للموت دابيا" كناية عن قوة الاستسلام والامتتال

$$
\text { لقضاء الله - تعالى -. }
$$

وتتجلى بلاغة الكناية هنا في تصويرها للموقف مصحوبًا ببرهانه، وذلك

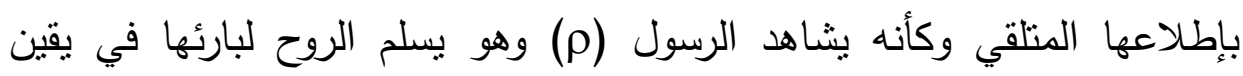

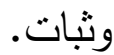

وورود هذه الكناية في سياق الجملة الحالية إمعان في التصوير يزيد هذه الحالة

$$
\text { وضوحًا وجلاءً. }
$$

وضاعف من جمال التصوير الكنائي هنا تعانقه مع التصوير الاستعاري القائم

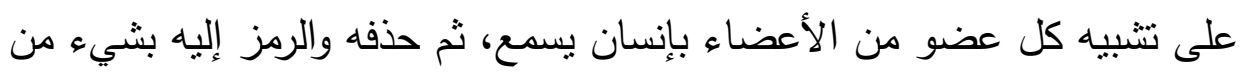

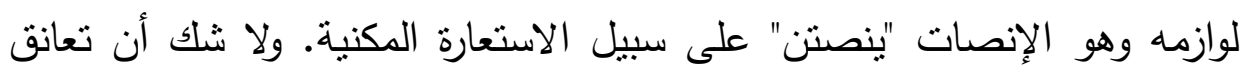

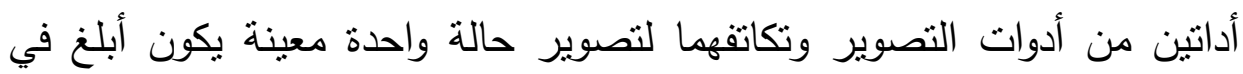

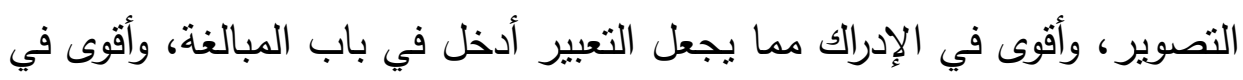

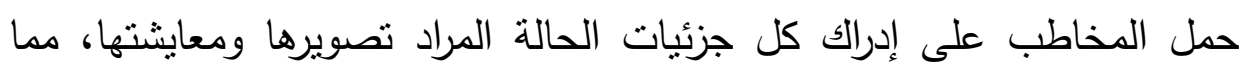
يؤكد براعة الثاعر في التعبير، ومقدرته الفائقة على تصوير المواقف ونقلها لل المخاطب كأنه يعايشها ويشاهدها.

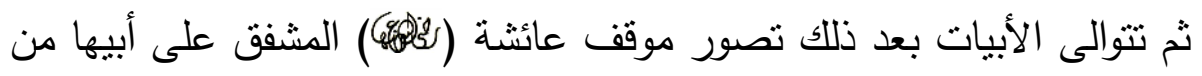

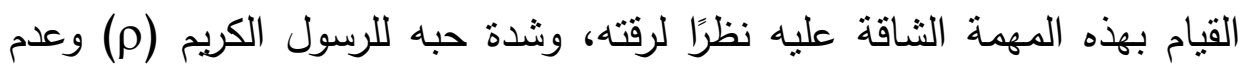
استطاعته الوقوف في مقام رسول الله (م)، يصور ذللك قوله:

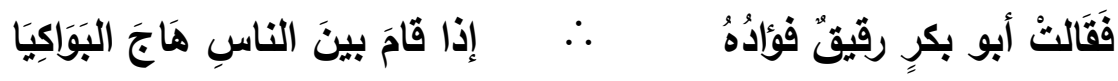


وقد تألقت الكناية في بيان موقف عائشة (كنو8) حيث اشتمل كل من شطري البيت عليها، فقولها: "أبو بكر رقيق فؤاده" كناية عن شدة التأثز، ورهافة حسه

وهذه الكناية لا يمكن معها إرادة المعنى الحقيقي لأن القلب معنوي لا يمكن وصفه بالرقة أو الغلظ، وإنما أراد الثاعر ما وراء التعبير برقة القلب من شدة التأثر ، وهي كناية عن صفة قربية. ومن لطائف هذه الكناية أنها أبرزت المعقول (رهافة الحس) في صورة محسوسة (رقة الفؤاد) مما بضفي عليها حسنًا وجمالاً ويدخل بها إلى أعماق المبالغة. وتكمن أبلغية هذه الكناية في أنها تدليل من عائشة (كنأهو) عن عدم

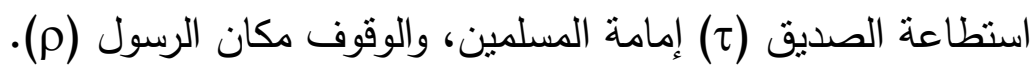
ولم يكتف الثاعر بإيراد دليل واحد في بيانه لموقف عائشة الرافض وإنما أتبع الكناية السابقة بكناية أخرى لا تقل روعة عن سالفتها وذلك قوله: "إذا قام بين الناس هاج البواكيا" كناية عن شدة التأثز أيضًا. وتبدو روعة هذه الكناية في أنها تعليل آخر يضاف لما سبق أن بينته من رقة فؤاد الصديق (ح) وعدم استطاعته الوقوف في مكانٍ يقف فيه النبي (م) لبيان موقفها المشفق على أبيها، وتدعيمه بالأدلة والبراهين من خلال هاتين الكنايتين القائميتن بمهمة بيان هذه الأدلة - كما

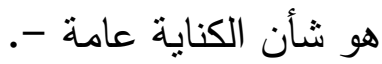
وقد وفق الثاعر في توظيف كل العناصر التعبيرية لترسم إطارًا يبرز روعة الكناية وذلك من خلال التعبير بالجملة الثرطية المفتتحة بإذا، والتي تدل على أنه متى تحقق الثرط "قيام بين الناس" تحقق الجزاء "هاج البواكيا" ولنا أن نتأمل التعبير بقوله: "بين الناس" دون أن يقال: أمامهم مما ييرز شدة التأثر ورهافة الحس، فأبو بكر وهو وسط الناس لا يمكنه الإنابة عن الرسول (م) فما بالنا إذا 
قام أمامهم، مما يؤكد شدة إثفاقها على أبيها، ساعده التعبير بالفعل "هاج" والجمع "البواكيا" مما يبرهن على استجماع الثاعر لكل الطرائق التعبيرية، وحسن توظيفها سواء على مستوى المفردات أو التراكيب وصولاً لتحقيق المعنى الذي تغياه. ويقابل هذا الموقف المشفق من عائثة (كنأه8) على أبيها، والراغب في إعفائه من هذه المهمة موقف الرسول (م) المصمّم على أن يكون الصديق (ح) هو إمام المسلمين في الصلاة لا غيره، يصور الثاعر ذلك قائلاً:

\section{فَقَالَ: أتتأباهُ صواحبُ يُوسُف}

وبالتأمل يتبين أن الثناعر كما ساعدته الكناية في البيت السابق على توضيح موقف عائشة (كنأول) فلم تضن عليه هنا أيضًا في بيانه لموقف الرسول (م) حيث اشتمل البيت أيضًا على موضعين للكناية:

الأول: قوله: "أتاباه صواحب يوسف" كناية عن خطأ عائشة في إثفاقها على الصديق (ح) ورغبتها في إعفائه من هذه المهمة التي لا يصلح لها غيره، ولذلك يذكرها بما كان من صواحب يوسف وخطئهن في نسبتهن الفاحشة إليه (v) وهذا هو ما يرنو إليه الشاعر من وراء هذا التركيب.

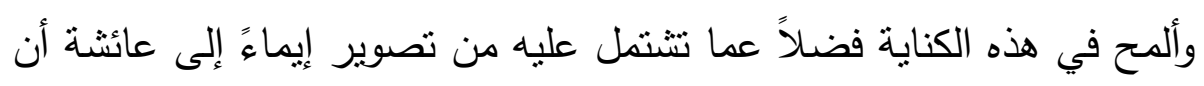
تعتذر عن موقفها، وتوافق مراد النبي (م) كما فعلت صواحب يوسف حين اعتذرن عن نسبتهن الفاحشة إليه، وتبرئته مما قد رموه به. وبمعاودة التأمل نجد أن الكناية

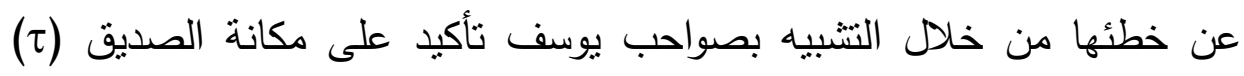
وقدرته على تحمل المشاق مهما كانت رهافة حسّه مادام ذلك في مصلحة الدولة الإسلامية، وتدعيم أركانها، وقد أكد ذلك موقفه في هذه الصدمة الثديدة حين لحق مقاف الرسول (م) بالرفيق الأعلى، وما حدث من زلزلة شديدة، وخطوب جسيمة فوقف ولف ولفه 
الصديق وهو المرهف الحس الثنديد التأثر والحب للرسول (م) صامدًا وجمع

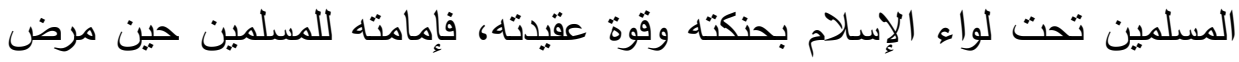
الرسول (م) لن نكون أقوى وأثند على نفسه من ريادته لهم حين لحق الرسول (م) بالرفيق الأعلى، مما يؤكد بعد نظر النبي (م) وخطأ عائشة في رفضها لإمامته للمسلمين. وبعد أن بينت الكناية السابقة خطأ عائشة (كأه8) تأني الكناية الثانية والتي اشتمل عليها الثطر الثاني من البيت بالرد القاطع من الرسول (م) والاختيار الذي لا يترك مجالاً للرفض أو الإباء "وغير أبي بكر أرى اله آبيا" كناية

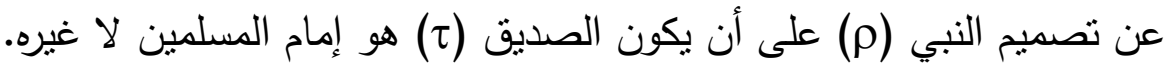
ومما يبالغ في قوة التصميم، ويساعد التصوير الكنائي على أداء المعنى نسبة هذا الاختيار إلى الله - تعالى - الذي يعلم بالأصوب والأصلح، والتعبير بفعل الرؤية "أرى" وذكر الصديق باسمه صراحة مما يؤكد تصميم النبي (م) على هذا الاختيار، ورد رفض عائشة وإلزامها بما يختاره الله - تعالى - لأنه: "ما كان لمؤمن ولا مؤمنة إذا قضى الله ورسوله أمرًا أن يكون لهم الخيرة من أمرهم".

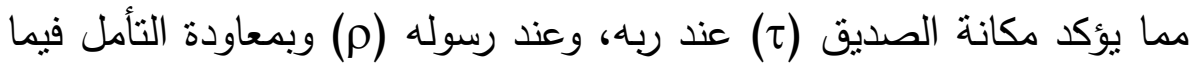
سبق من كنايات مصورة لموقف مرض الرسول (م) وما حدث فيه من أخذ ورد بين عائشة والرسول (م) نجد أن الكناية قد وردت خمس مرات في تصوير الثاعر لهذا الموقف وكانت غاية في البلاغة والبراعة وقوة التصوير ، فالكناية الأولى منها "وأعضاؤه ينصنت للموت دابيا" صورت لنا هذا المشهد المحزن الذي يسلم فيه الرسول (م) الروح لخالقها، وقوة اعتمال الموت في جسده الثربف (م) صورت الكناية ذلك وكأننا نشاهد هذا الموقف ونعايثه، أما الأربعة مواضع الأخرى للكناية فجاءت على السوية بين موقف عائشة (كأفه6) وموقف الرسول (م) حيث استغرق بيان كل موقف منها بينًا من القصيدة، واشتمل كل بيت على موضعين للكناية، 
ففي بيان موقف عائشة نجد قوله: "أبو بكر رقيق فؤاده" "إذا قام بين الناس هاج البواكيا"، وفي بيانه لموقف الرسول (م) نطالع الكناية "أتأباه صواحب يوسف"، "وغير أبي بكر أرى اله آبيا"، وكلها كنايات غاية في الوضوح ساعدت على بيان هذه المواقف في قوة ووضوح، وكلها كنايات عن صفة قريبة، مما يؤكد دور الكناية في التصوير ، وقدرتها على نقل المشاهد كاملة. 


\section{الكناية في تصوير موقفه (ح) حين لحق الرسول (م) بالرفيق الأعلى}

لعلَّ خير شاهد، وأصدق برهان على ريادة الصديق (ح) وما له من مواقف عظيمة، ودور كبير في إرساء دعائم هذه الدولة الفتية هو دوره عند وفاة النبي (م) هذه الحادثة العظيمة والفجيعة المؤلمة التي ألمت بالمسلمين في وقت كانوا يعدون النبي (م) هو الملاذ بل هو الحياة كلها، مما جعل لهذه الحادثة أثرًا بالغًا

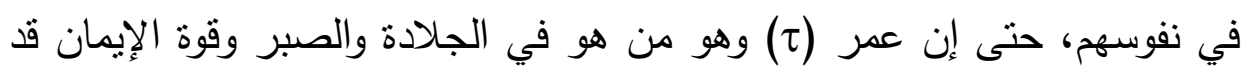
زلزلته هذه الحادثة حتى جعلته يهتاج كأسد فاتك يهدد ويتوعد كل من يتلفظ بموت النبي (م) بضرب عنقه.

إلا أن أبا بكر (ح) كان - كعادته - له دوره المشرق، وأثرهُ القوي في تثبيت النفوس، وإرجاعها إلى الله - تعالى - الحي الذي لا يموت حين أخذ بيد الفاروق

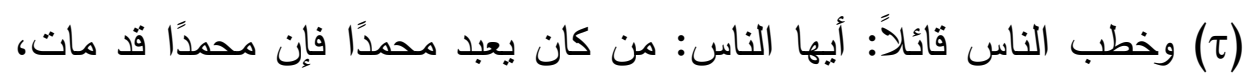
ومن كان يعبد الله فإن الله حي لا يموت ..." وتلا عليهم قول الله - تعالى - "وما محمد إلا رسول قد خلت من قبله الرسل ...." فعاد الناس إلى صوابهم، وتجمع شمل الصحابة - رضوان الله عليهم - بعد أن تمزقت قلوبهم، وأنستهم الفجيعة أسبقية هذا الأمر المحتوم الوارد في كتاب الله - تعالى -.. يصور الثاعر هذا الموقف قائلاً: 


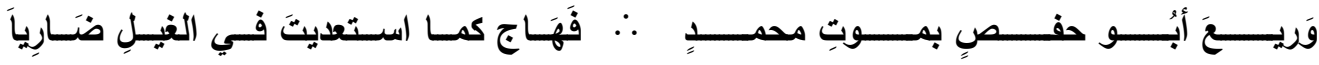

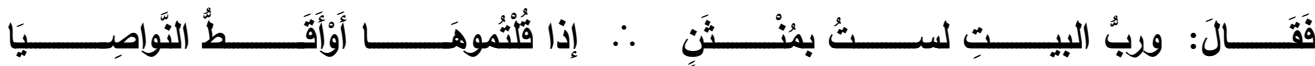

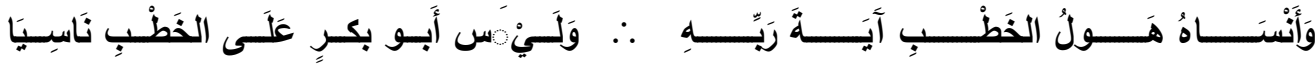

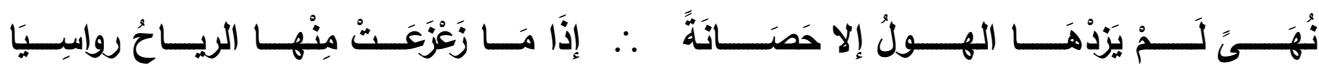

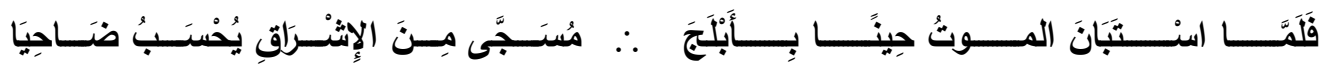

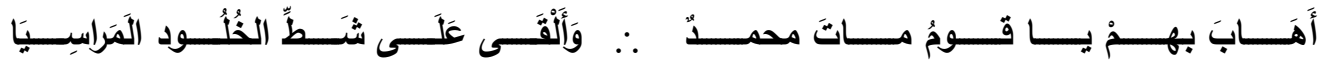

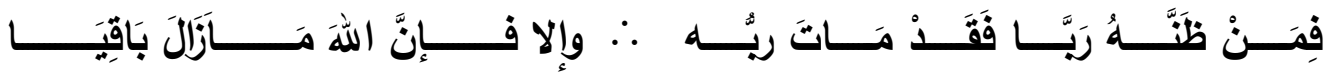

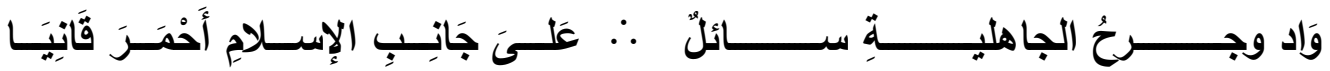

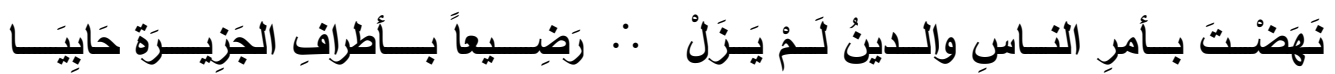

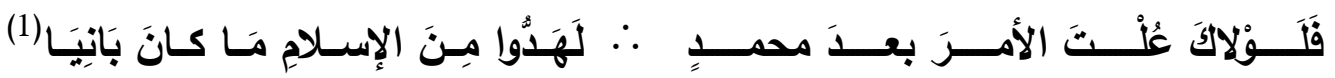
وقد حفلت هذه الأبيات بمواطن متعددة للكناية، فقوله: "وريع أبو حفص بموت محمد" كناية عن شدة الخطب، وهول الفاجعة.

وهذه الكناية يمكن معها إرادة المعنى الحقيقي، ولكن المقصود الأهم هو ما وراءه من تصوير شدة الخطب توصلا لبيان موقف أبي بكر لاحقا. وقد صورت هذه الكناية موقف عمر (ح) وما اعتراه من فزع بسبب فقد الرسول (م) أبلغ تصوير

ومما بيالغ في قوة التصوير، ويبرهن على شاعرية المصري اختياره الكنية (أبو حفص) دلالة القوة والثجاعة دون الاسم - عمر - أو اللقب - الفاروق - تأكيدًا

(1) الديوان (309/2، 310)، الغيل: الأمـاكن التي تسكنها السباع، أقط: أقطع النواصسي: 
لثدة الخطب حتى إن عمر وهو المكنى بأبي حفص قد ارتاع من هولها فما بالنا بغيره من الصحابة - رضوان الله عليهر - ممن هم دون عمر في الثجاعة. وتأخذ هذه الكناية في البيت شكلاً آخر من الجمال حين ترشح بالتشبيه بعدها المكمل للتصوير في قوله: "فهاج كما استعديت في الغيل ضاريا" مما يحدث تعانقًا بين لونين من ألوان البيان لتصوير الحالة المراد تصويرها أبلغ تصوير، ويبرهن على مقدرة الثاعر العجيبة على دمج هذه الألوان، وحسن توظيفها حتى تتهض لته برسم الصورة واضحة جلية يراها كل من يتطلع إليها. وإذا كانت هذه الكناية ومعها التشبيه يتعانقان في هذا البيت لتصوير سلوك الفاروق

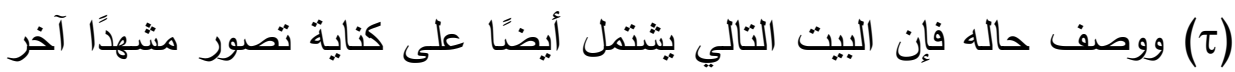
من مشاهد الفزع والهلع التي أصابت الفاروق (ح). وقد تمثل هذا المشهد في الجانب القولي بعد أن صورت الكناية السابقة الجانب السلوكي، يوضتح ذلك البيت:

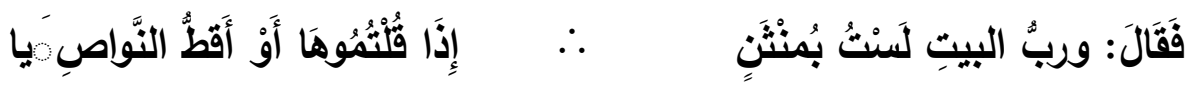
قوله: "أو أقط النواصيا" كناية عن شدة الوعيد لمن يتلفظ بخبر وفاة النبي (م)، وقد تكاتف مع الكناية في بيان شدة القتل التعبير بالفعل أقط دون أقطع وهذه الكناية إثنارة واضحة إلى شدة غيظ عمر (ح) وقسوته مع من يتلفظ بهذا الخبر المؤلم، كما أن هذه الكناية جارية على طريقة العرب في كناياتهم عن شدة الوعيد بقطع الناصية، ودق العنق، وقطع الرقبة، كناية عن القتل ولو كان بغير ذلك. مما يحمل معه معاني كثيرة تعجز الألفاظ المباشرة عن حملها، يقول أستاذنا الدكتور / لئهي محمد أبو موسى أنهم (حين يذكرون دق العنق، وقطع الرقبة، كناية عن القتل ولو 
كان بغير ذللك فإنهم يقصدون إلى التشنيع، وإبراز عنصر القسوة والعنف والإيجاع

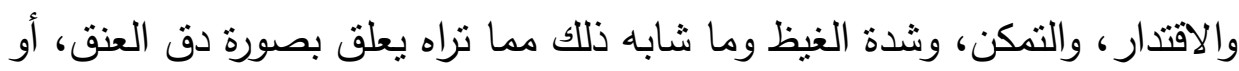
حز الرأس) (1) ولا شك أن كل هذه المعاني ماتلة في الكناية التي أوردها الثاعر.

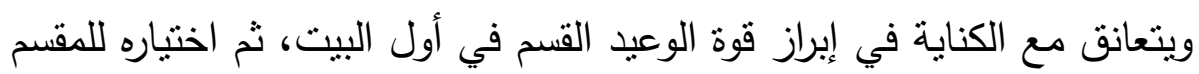

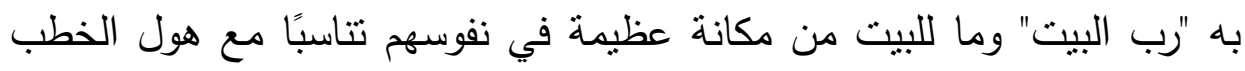
وشدة الفاجعة.

وإذا كانت هذه الكناية تصور شدة الوعيد لمن يقول بموت الرسول (م) فإنها

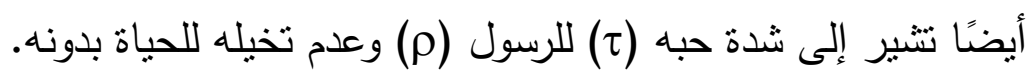

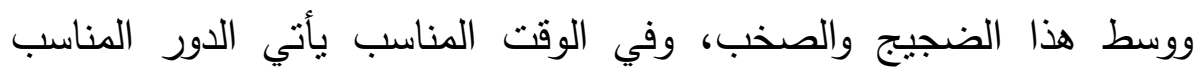

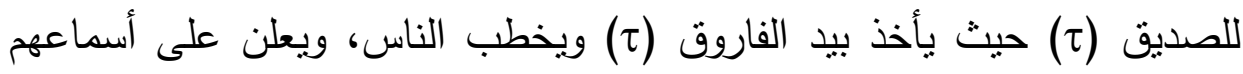

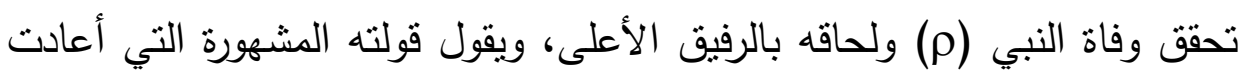

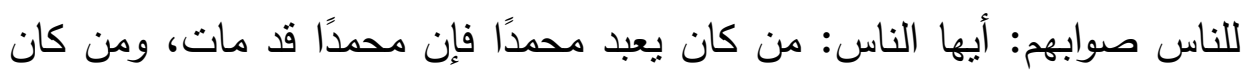

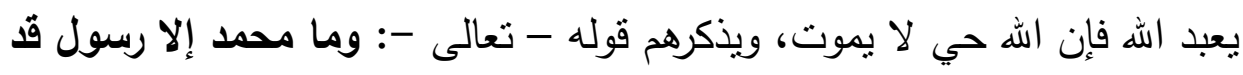
خلت من قبله الرسل .......

فكأن الناس لم بسمعوها إلا يومها، فأخذوا يرددونها معتبرين بما فيها، ملتقين

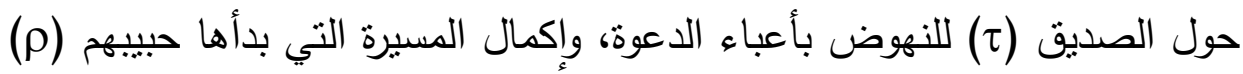

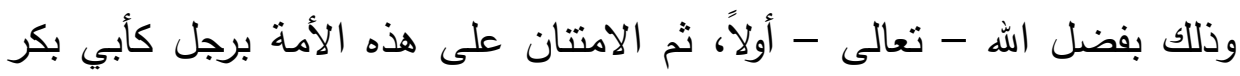
ثنانيًا.

يصور ذلك قوله:

(1) التصوير البياني، د/ محمد أبو موسى، صد(376). 


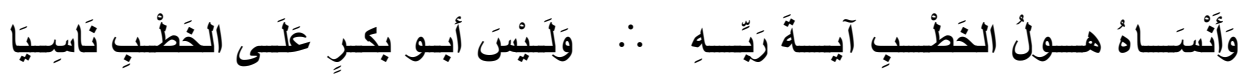

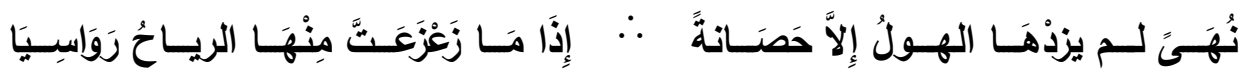

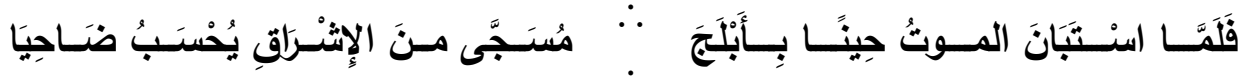

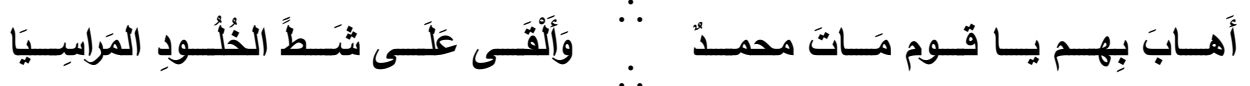

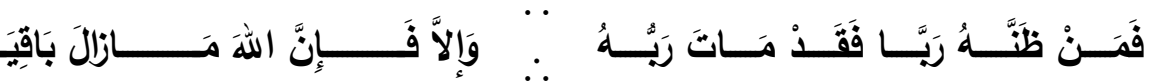

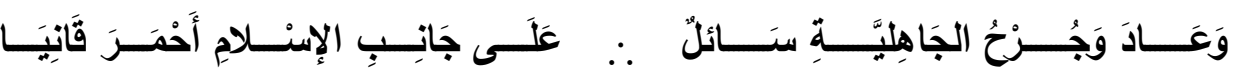

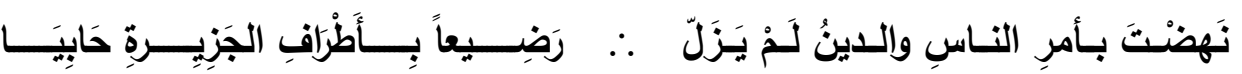

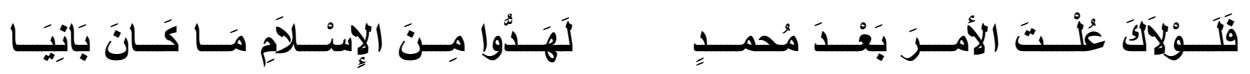

وقد تألقت الكناية ضمن ما حوته الأبيات من ألوان بلاغية وذللك بورودها مرتين: - n - n الأولى: في البيت الرابع حيث قوله:

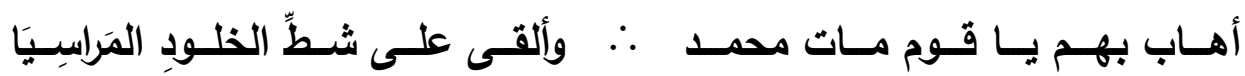
والثطر الثاني في البيت "وألقى على شط الخلود المراسيا" كناية عن تحقق وفاة الرسول (م) وتأكيد موته. وتتجلى بلاغة الكناية هنا في أنها تدليل وتقرير على ما قبلها وهو قوله "مات

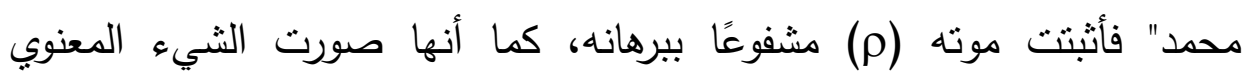

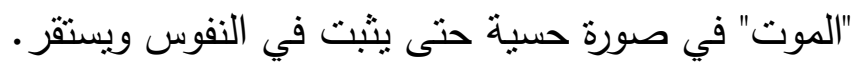
وضاعف من جمال هذه الكناية تولدها من رحم التصوير الاستعاري في تصوير الرسول (م) بمرتحل وصلت سفينته إلى الثاطئ منهية الرحلة نأكيدًا

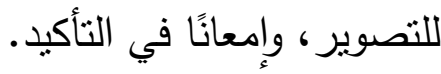




\section{الثانية: في البيت السابع حيث قوله:}

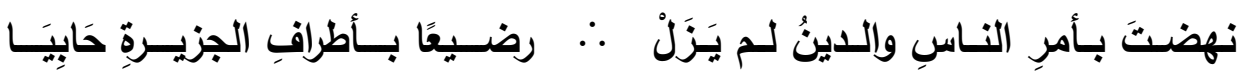

وقوله: نهضت بأمر الناس "كناية عن تحمله المسئولية، وحسن قيامه بأحوال

الرعية.

وهذه كناية عن صفة بعيدة لا يتوصل إلى الكناية إلا بعدة وسائط فالنهوض دليل على توفر الرغبة في فعل شيء ما، وتوفر الرغبة دليل على إدرالك أهميته، وإدراك الأهمية دليل على حسن القيام به، فالكناية هنا مكونة على حد تعبير أستاذنا الدكتور / محمد أبو موسى - من عدة حلقات كل واحدة منها نسلم خيط

الفكرة وشعاع الإدراك إلى الأخرى، حتى تتنهي إلى المقصود. وترجع بلاغة الكناية هنا إلى أنها قدمت المعنى مشفوعًا بدليله مصحوبًا ببرهانه، كما أنها أيضًا أبرزت المعقول "تحمل المسئولية" في صورة محسوسة مما يزيدهُ استقرارًا في النفوس. ومما يتعاضد مع الكناية في إبراز المعنى التعبير بلفظ "الناس" دون أن يخص

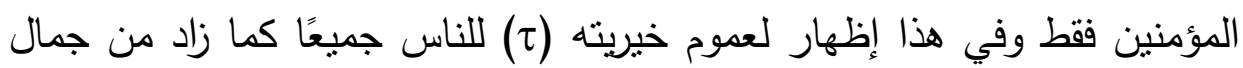
الكناية أيضًا ترشيحها بالتشبيه بعدها في قوله: "والدين لم يزل رضيعًا بأطراف الجزيرة حابيا" مما يظهر عظم المسئولية، وكثرة المشاق مما يحتم على من يتصدى لها أن يكون على قدرها، مما يبرهن على عظم دور الصديق (ح) ويثبت جدارته بهذا الدور • 
ولنا أن نتأمل كيف اختار الثاعر المشبه به "الطفل الرضيع" مما يجعله يحتاج إلى حسن رعاية ورفق وتحمل مسئوليته كاملة، وهي صورة استرفدها الثاعر من عالم الطبيعة المليء بكل مقومات الحسن والجمال.

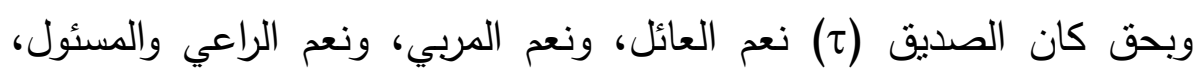
فلولاه لانهدم ما كان قد بناه الرسول (م). وبالتأمل فيما سبق من كنايات مصورة لهذا الموقف نجد أن الكناية قد وردت

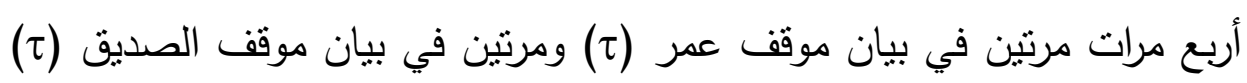
وكان لها في كل المواضع تتاغم وتتاسق مع السياق، حيث قدمت الأدلة في كلا الموقفين. 


\section{الكناية في تصوير موقفه (ح) من إنفاذ جيش أسامة بن زيد لغزو الروم}

توطئة:

كان الرسول (م) قد جهَّز جيشًا لغزو الروم، وكان على رأس هذا الجيش أسامة بن زيد بن حارثة، وتحته جمع غفير من كبار الصحابة - رضوان الله تعالى عليهم -، لكن شاءت إرادة الله - تعالى - أن يمرض النبي الكريم (م) ويلحق بالرفيق الأعلى قبل أن يخرج الجيش. وما إن آلت الأمور إلى أبي بكر (ح) حتى إنى كان عليه أن ينظر في أمر خروج هذا الجيش بعض أن واجهته بعد الصعاب من الصن الهن تخوف البعض من خروج الجيش بعد أن زلزل كيانهم موت النبي (م) ، والبعض هرن منهم أيضًا أراد تغيير رئاسة الجيش ونزعها من أسامة المولى ابن الموالي وإعطائها لأحد كبار الصحابة، كل هذه المواقف كانت عبئًا ثقيلاً على كاهل أبي بكر () وعقبات في طريقه عليه أن يواجهها بكل حزم وروية. وبالرجوع إلى القصيدة نجد أن الثاعر قد أفاض في الحديث عن هذا الموقف، حيث استغرق بيانه جزءًا كبيرًا من القصيدة مما يجعلني أستعرضه تحت مواقف إنف جزئية ليتنين للقارئ الكربم دور الكناية في كل موقف منها في التصوير، وقدرتها على إبراز المعنى المراد، وذللك على النحو النالي: أولاً: موقفه من إنفاذ الجيش: يقول الثاعر:

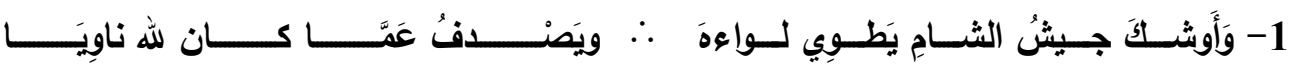

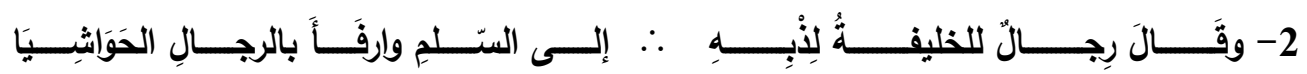

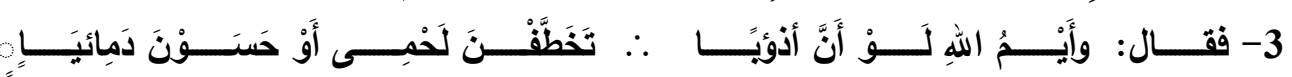




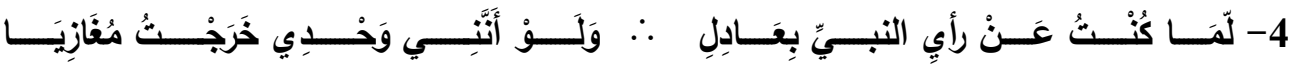

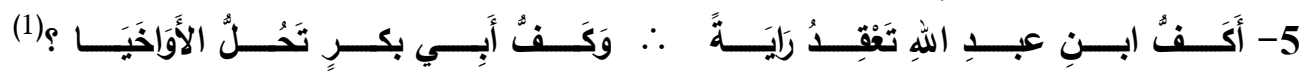

والأبيات تبين تصميم أبي بكر (ح) على خروج الجيش بعد أن أوشك على القعود نظرًا لخوف بعض الصحابة - رضوان الله عليهح - على المسلمين، ورغبتهم في التمهل في إرساله إلى أن تلتئم جراحاتهم، وتقوى صفوفهم بعد هذا

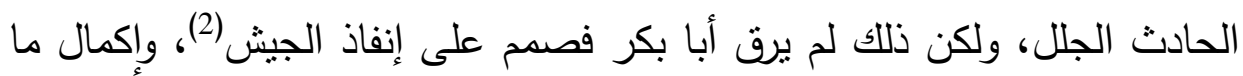
قد بدأه النبي (م). وقد استخدم الثاعر الكناية ضمن ما استعمله من ألوان بلاغية لتصوير هذا الموقف وإبرازه إلى المتلقي في صورة رائقة. فقي البيت الأول يقول:

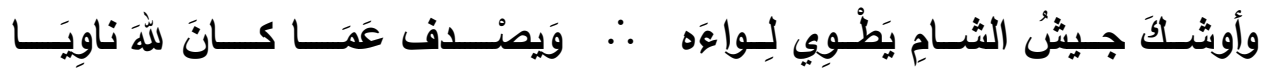
فقوله: "يطوي لواءه" كناية عن القعود، وعدم الخروج للغزو .

الديوان: (310/2، 311)، المفردات: يصدف: يرجع، ارفأ بالرجال الحواشيا: ابتعد بهم

$$
\text { عن الحرب، الأواخي: العهود. }
$$

ينظر : البداية والنهاية للإمام الحافظ أبو الفداء إسماعيل بن كثير الدمشقي، خرج أحاديثه:

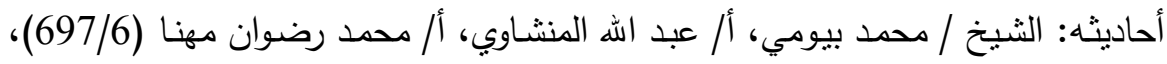
مكتبة الإيمان، المنصورة. 
والكلام هنا يمكن أن يراد به حقيقته، لكن الثاعر رمى به مردى أبعد من ذلك وهو ما وراء طيِّ اللواء من التقاعس والتثاقل عن الفعل، لأن طي اللواء بيتلزم القعود وعدم الخروج.

ولا يخفى ما للكناية هنا من دور عظيم في تصوير حالة الإحباط والفتور التي أصابت المسلمين بعد وفاة النبي (م) ليبرز بذلك دور الصديق (ح) بعد ذللك في إنهاض همههم، وإثارة حميتهم. ويتآزر مع الكناية في نأكيد تقاعسهم عن القتال التعبير بالفعل "أوشك" في مطلع البيت الدال على المقاربة، ثم إسناده إلى مجموع الجيش "جيش الثام" ثم الوصل بين الفعلين "يطوي" الدال على التقاعس والعزم على عدم الخروج، و "يصدف" الدال على رجوعهم بالفعل، وتركهم لما كانوا ينوونه. وتجاه هذه الصورة المتقاعسة، والموقف المخزي من الجيش يأتي دور الصديق (ح) وتصميمه على إنفاذ الجيش، وذلك في بيتين تاليين مرتكزين على الكناية كدعامة أساسية في توضيح ما أراد الثاعر من معان وهما:

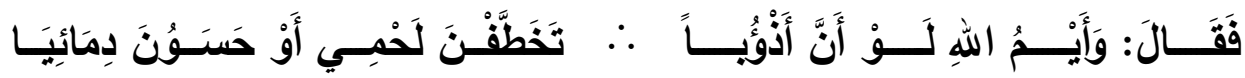

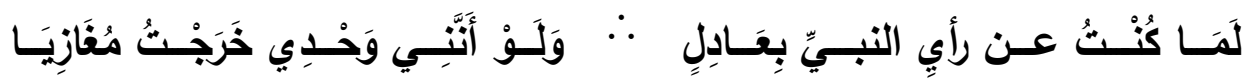

وقد توافرت الكناية في البينين للتأكيد على شيء واحد هو تصميمه (ح) على إنفاذ الجيش وخروجه للغزو رغم اعتراض المعترضين، وتقاعس المتخاذلين، ومواطن الكناية في البيتين قوله: "لو أن أذؤبًا تخطفن لحمي أو حسون دمائيا" في البيت الأول، وقوله "ولو أنني وحدي خرجت مغازيا" في البيت الثاني. 
وهاتان الكنايتان تبرزان شدة التصميم، وقوة العزم على الغزو، وعدم تغيير ما قد بدأه الرسول (م) حتى ولو كان الثمن أن يدفع حياته، أو يخرج وحده لقتال الأعداء، كل ذلك في صورة مشرقة، وعبارة قوية مصورة. 
ثاتيًا: موقفه من نزع اللواء من أسامة بن زيد:

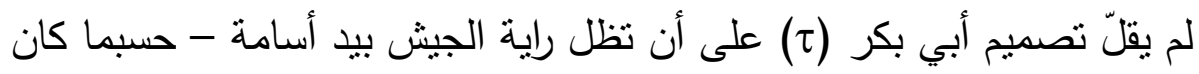
الرسول (م) قد فعل - عن تصميمه على إنفاذ الجيش، خاصة وأن بعض إن الصحابة ممن كانت لا نزال بهم بعض طباع الجاهلية من التفاخر بالحسب والجاه

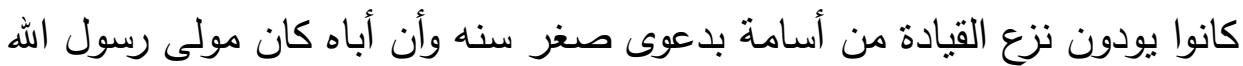

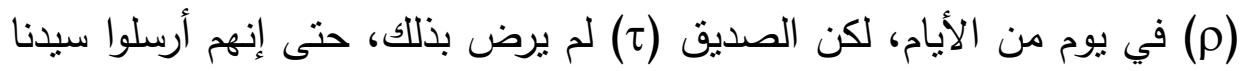

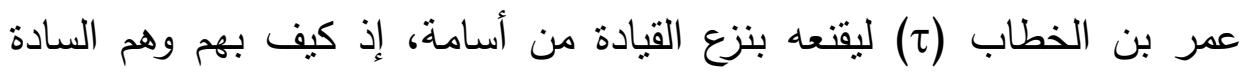
يكونون تحت لواء مولى من الموالي، ولكن الصديق (ح) يصر على موققه، ويصمم على أن نظل القيادة لأسامة، إذ كيف لأبي بكر أن ينقض عهذًا عقده

$$
\text { رسول الله (م)(1) ..... }
$$

ولا شك أن هذا الموقف قد أعلى من شأن أسامة (ح) ورفع من قدره حتى كاد أن بطاول بعنقه عنان السماء. يصور الثاعر ما حدث في هذا الموقف قائلاً:

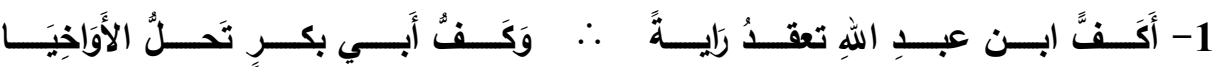

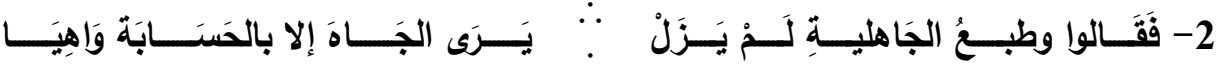

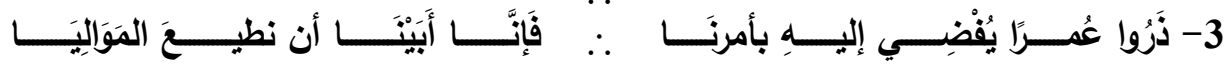

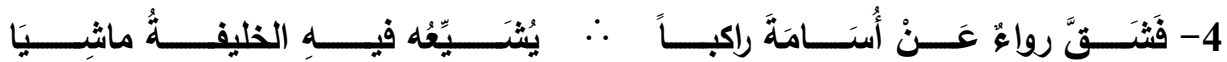

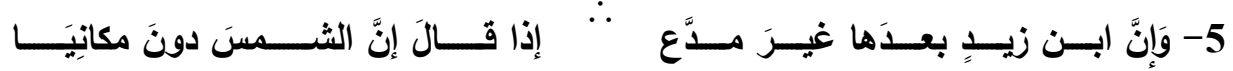

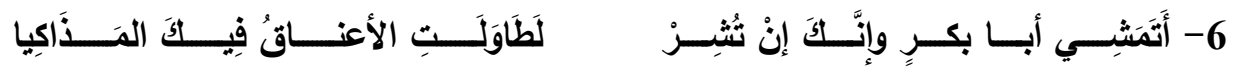

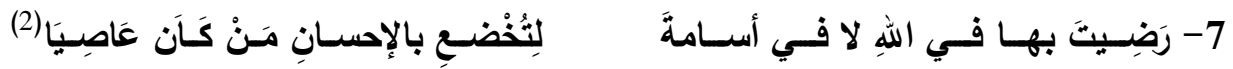


(1) عَاصص

$$
\begin{gathered}
\text { الأول: في البيت الأول حيث الكناية هنا في موضعين قوله: }
\end{gathered}
$$

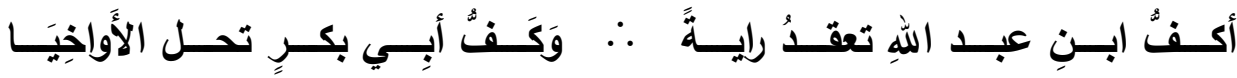

والبيت كله كناية مركبة عن تصميم أبي بكر (ح) على أن تظل القيادة لأسامة

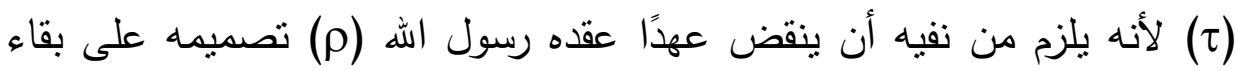
القيادة لأسامة لأن الذي أعطاه الراية هو رسول اله (م). وفضل الكناية على الحقيقة هنا أنها قدمت لنا هذا المعنى - التصميم والإصرار - مصحوبًا بدليله مقرونًا ببرهانه، وذلك بإيراد حالتين متقابلتين: حالة عقد الراية لأسامة من قبل الرسول (م) وحلَّها من أبي بكر . وضاعف من جمال بإيرال الكناية في البيت ورودها في سياق الاستفهام الإنكاري المفتتح به البيت أكف ابن عبد الله .... المؤكد لتصميم الصديق (ح) على أن تظل القيادة لأسامة وذلك بإنكاره على نفسه أن يحل عقدًا أبرمه رسول اله (م) ساعده الطباق بين الفعلين تعقد وتحلّ مما يحدث تكاتفًا لعناصر النظم مع الكناية للكثف بوضوح

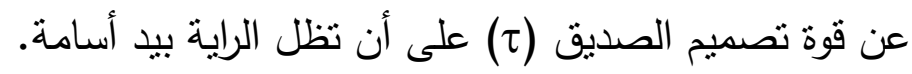
الثاني: في البيت الخامس حيث قوله:

(1) الديوان (311/2)، الأواخي: العهود، المذاكي: الخيل. 


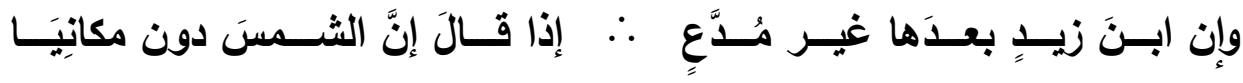

وقوله: "إن الثمس دون مكانيا" كناية عن علوّ المنزلة، ورفعة المكانة؛ لأن

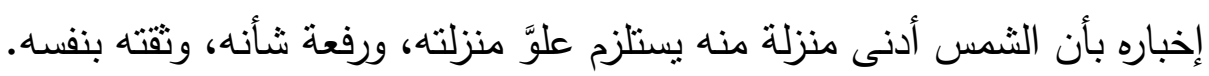

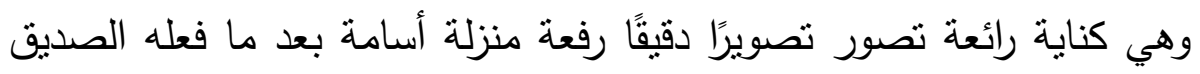

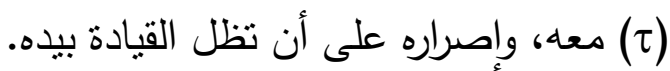

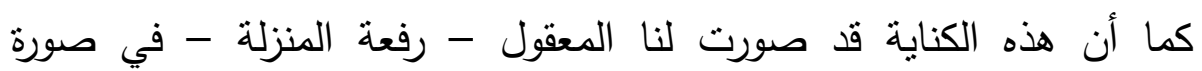
محسوسة يراها كل من يتطلع إليها، وهي كناية قريبة واضحة كما ترى.

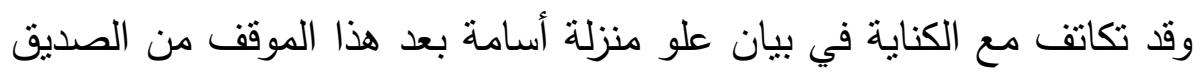

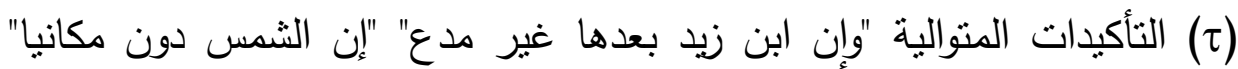
تأكيدًا لعلو المنزلة، ورفعة الثنأن. ثنالثًا: الكناية في تصوير الثنزف ورفة وصاياه للجيش:

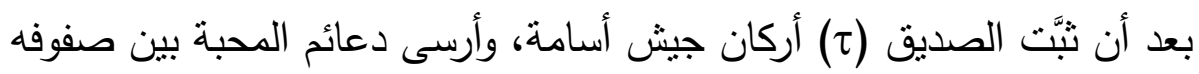
باللين والإحسان، أخذ يوصي الجيش وصايا غالية. هذه الوصايا تبقى غرة في

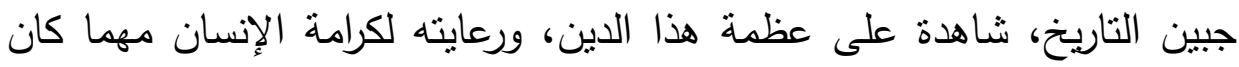
لونه ومعتقده، كما أنها أيضًا نظل برهانَ

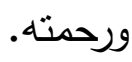

يصوغ الثناعر هذه الوصايا في أسلوب رائع، وتصوير خلاب قائلاً:

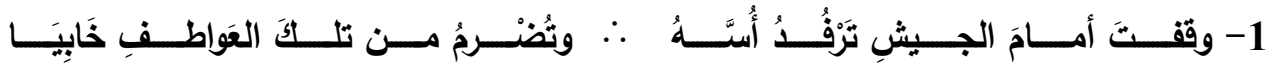

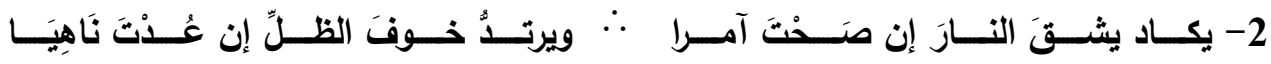

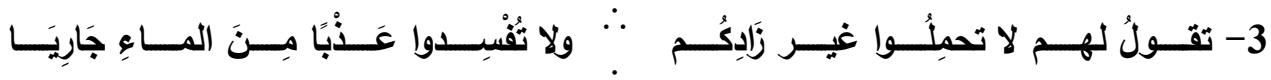

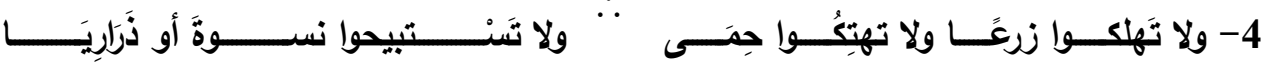




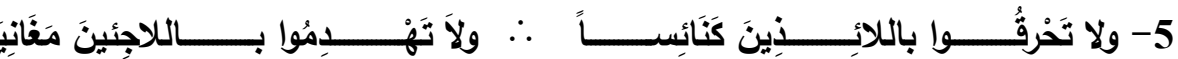

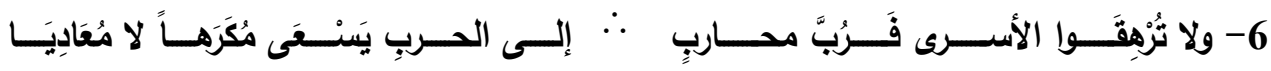

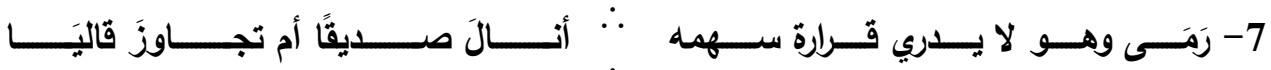

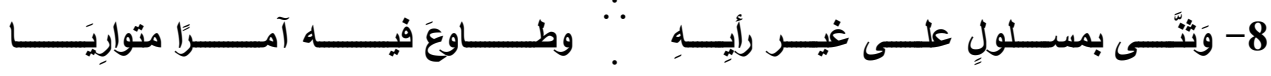

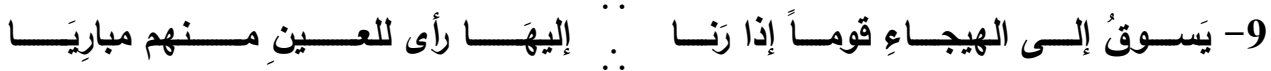

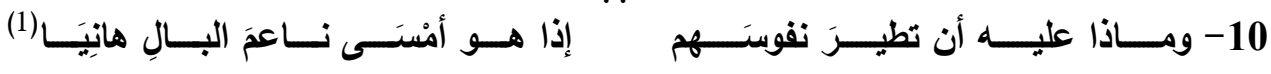

والأبيات واضحة الدلالة على ما تحمله من معان، وقد وردت الكناية فيها في عدة مواضع جاءت على النحو التالي: في البيث الثاني حيث قوله:

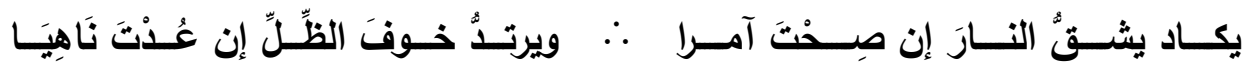

وقد حمل كل من شطري البيت كناية عن نفس المعنى الذي تضمنه الثطر الثاني، فقوله: "يكاد يشق النار إن صحت آمرا" كناية عن كمال انقياد الجيش

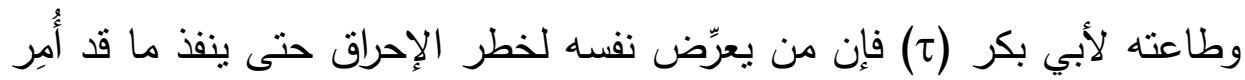
به لاليل ساطع على كمال انقياده وطاعته للآمر . ويأتي الشطر الثاني من البيت ليؤكد على نفس المعنى من خلال الكناية أيضًا في قوله: "ويرتد خوف الظل إن عدت ناهيا" كناية عن كمال الانقياد، وقوة

(1) الديوان (312/2، 313)، اللائذين: المحتمين، المغاني: البيوت المأهولة بأهلها، مباريا: محاربا. 
الامتتال، ولنا أن نتأمل التعبير بالفعل "يرتد" وما يوحي به من سرعة التتفيذ نأكيدًا

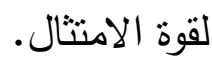
والمعنى الحقيقي مراد هنا مع المعنى الكنائي وهو مما يبالغ في عظمة الكناية،

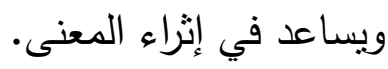
وتتجلى بلاغة الكناية في الموضعين في أنها قدمت لنا المعنى - كمال الانقياد

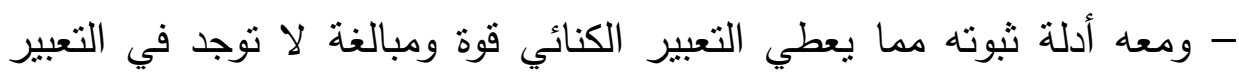
الحقيقي.

ومما يبالغ في روعة الكناية في الموضعين أنها صورت المعنى من خلال

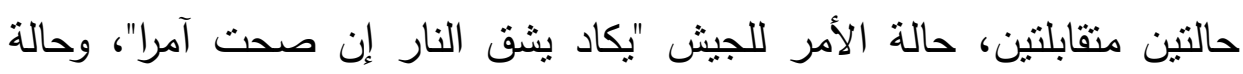

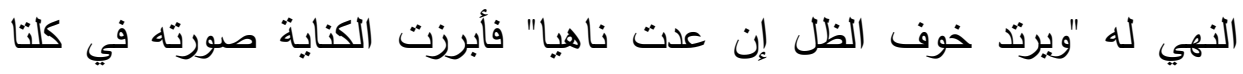

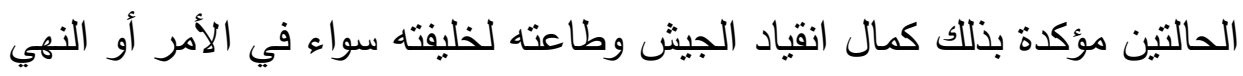
مما يدلل وبقوة على حسن الانقياد. وكما جاءت الكناية هنا وكان لها دورها الرائد في نأدية المعنى تجلت الكناية

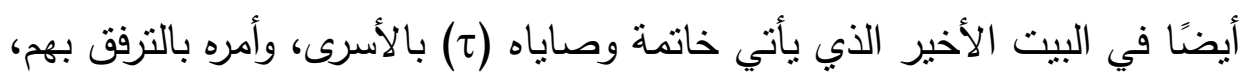

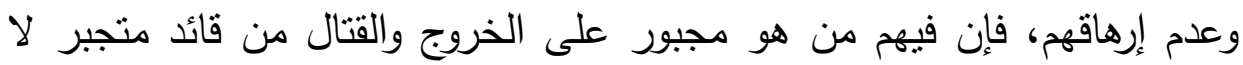

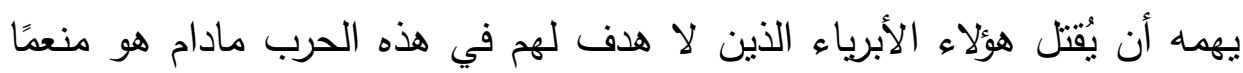

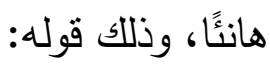

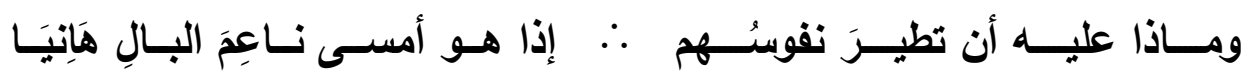
وقد اشتمل هذا البيت على موطنين للكناية: 
الأول: قوله: "تطير نفوسهم" كناية عن شدة الخوف والفزع من الحرب، وملاقاة

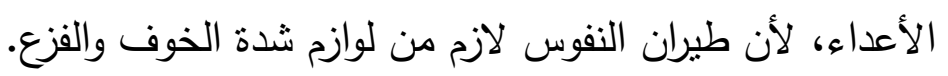

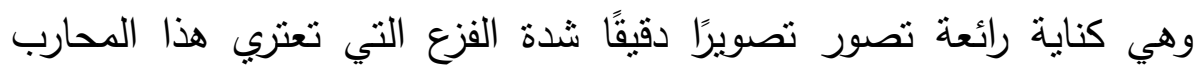
المجبور على الحرب، وتتناغى مع سياق الحديث عن الغزو والقتال، فإن من يقاتل لغير هدف كهذا المحارب المجبور لا شك يصيبه من شدة الخوف والفزع ما

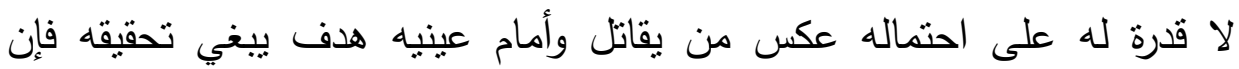
انشغاله بالظفر بمطلوبه، وتحقيق هدفه ربما يخفف من وطأة الخوف، ويهدئ من لان روعة الفزع. - مان. ومعلوم أن الكناية هنا أبلخ من التصريح كما لو قال: "وماذا عليه لو فزعوا"

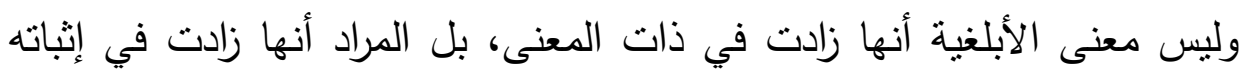

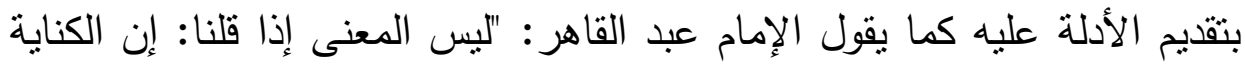

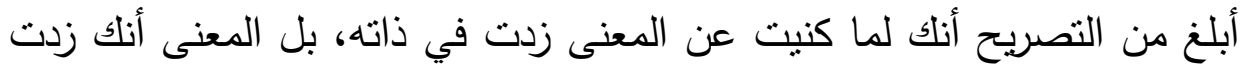

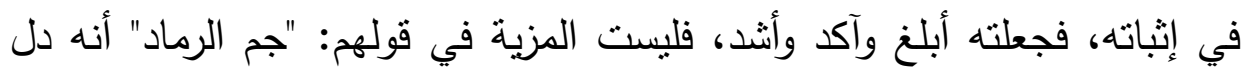

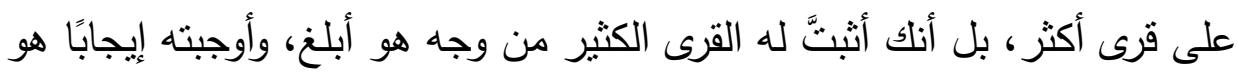

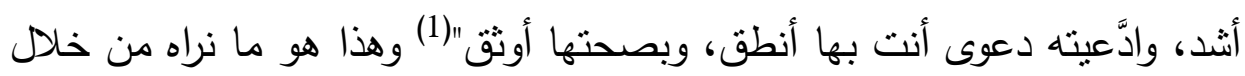
هذه الكناية. وضاعف من جمال هذه الكناية تولدها عن الاستعارة تأكيدًا للتصوير ، وإمعانًا

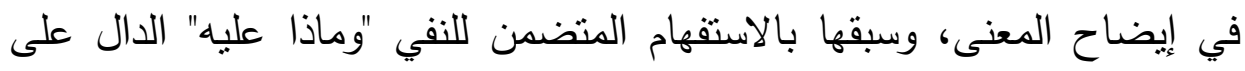

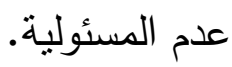


الثاني: قوله: "إذا هو أمسى ناعم البال" فنعومة البال كناية عن صفة الأمان،

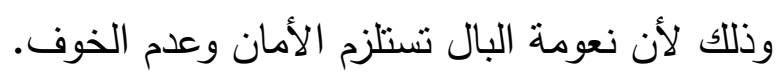

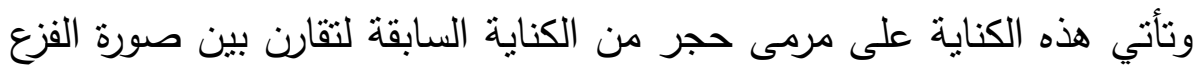

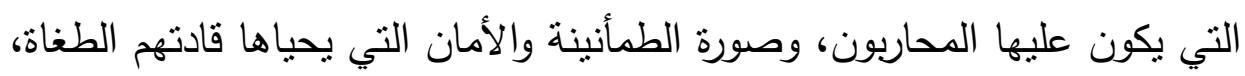
وهي كناية عن صفة قريبة.

وتبدو روعة الكناية هنا في تصويرها للمعقول "الأمان" في صورة محسوسة مما صله يجعله يسنقر في القلوب، ويرسخ في الأذهان. والكنايتان كما هو واضح لا يمكن فيهما إرادة المعنى الحقيقي. رابعًا: الكناية في تصوير أثر الوصايا على الجنود:

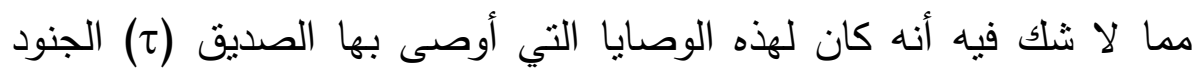

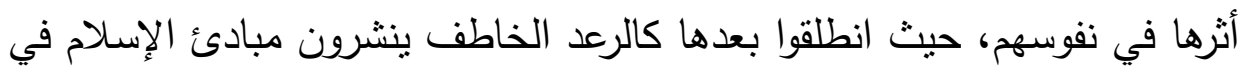

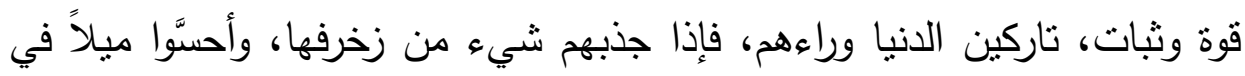

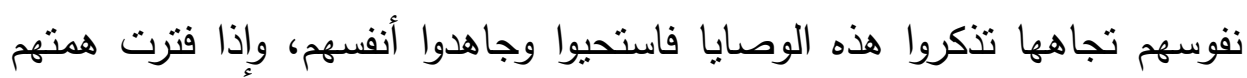

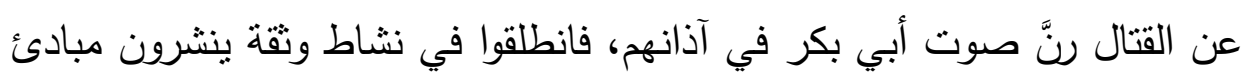
هذا الدين، ويرفعون رايته. يصور الثاعر ذلك قائلاً:

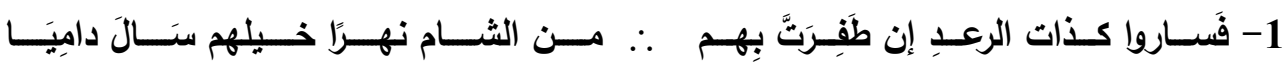

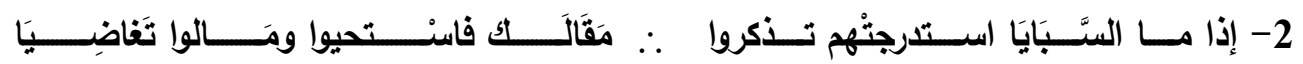




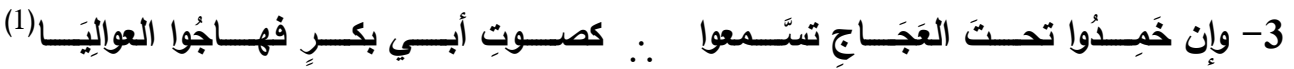

وقد وردت الكناية هنا في موضعين:

الأول: قوله: "ومالوا تغاضيا" في البيث الثاني، حيث يدل هذا التركيب على نأثرهم بما أوصاهم به الصديق (ح) من عدم استباحة النسوة والذراري.

وقد أطلعتتا هذه الكناية على شدة تأثز الجنود بوصايا الصديق (ح) وذلك بإنيانها بالدليل الحسّي المدلول عليه بقوله "ومالوا تغاضيا"، وهو صورة محسوسة

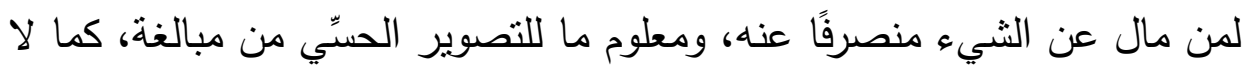
يخفى ما للكناية من دور في إثبات المعنى بإيرادها الدليل على تأثرهم مشاهدًا محسوسًا يراه كل من بيتلع إليه.

ومما يبالغ في شدة تأثزهم سبق الكناية بصفة أخرى دالة على التأثز وهي حياؤهم عندما يتذكرون الوصايا، وهذه الصفة مدلول عليها صراحة في قوله "فاستحيوا" الذي يصور تأثزهم بالوصايا داخليًا، ثم ما يلبث أن بظهر هذا التأثز عليهح خارجيًا من التركيب المشتمل على الكناية "ومالوا تغاضيا" مما يثبت دور الكناية الرائد في إثبات المعاني وتقريرها.

ولا يخفى ما لعطف الفعل "استحيوا" على التذكر بالفاء من وقع عظيم، وتدليل بالغ على أنهم بمجرد التذكر يحدث الحياء والانصراف عما مالت نفوسهم إليه،

الديوان: (313/2)، العجـاج: غبـار المعركـة، العـوالي: السـيوف القويـة، السبايا: غنـائم 
مما يؤكد شدة تأثرهم والثزامهم بما أوصاهم به خليفتهم (ح) ويحدث تآزرًا للنظم مع الكناية لتأكيد شدة التأثز .

الثاني: في البيت الثالث الذي يصور أثرًا آخر من آثار هذه الوصايا، ويضيف

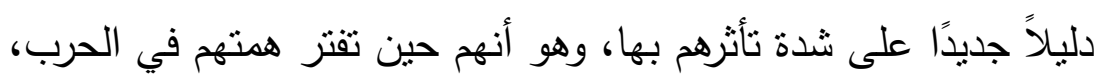

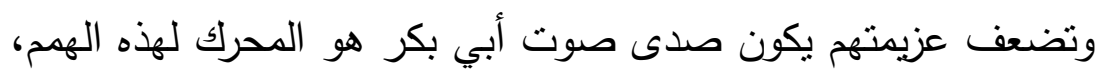

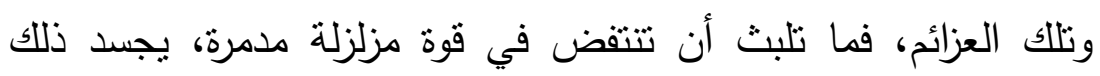
قوله: - ق وله

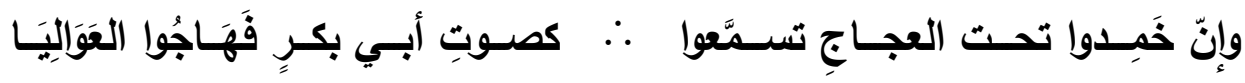
وقوله: "هاجوا العواليا" كناية عن هرعهم وفزعهم إلى الحرب، وملاقاة الأعداء.

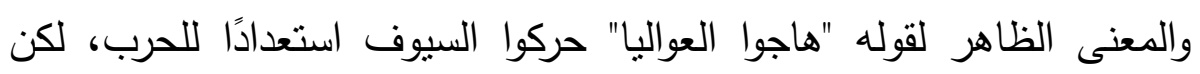

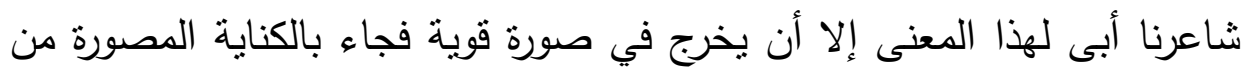
خلال المعنى المتوارى خلف هذا المعنى الظاهر.

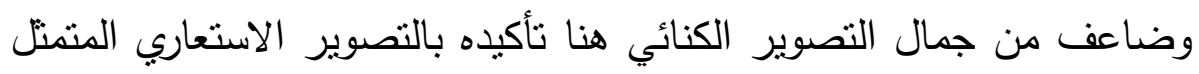

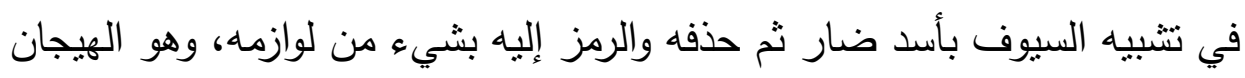
على سبيل الاستعارة المكنية ليدمج الثاعر - كعادته - بين لونين من ألوان البيان تأكيدًا للنصوير ، وإمعانًا في إعطاء المبالغة حقها.

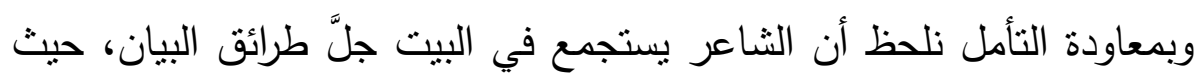
يسبق موطن الكناية بالتتبيه "تسمعوا كصوت أبي بكر" حتى تكتمل الصورة وتتضح من جميع زواياها. 


\section{الكناية في تصوير موقفه من المرتدين}

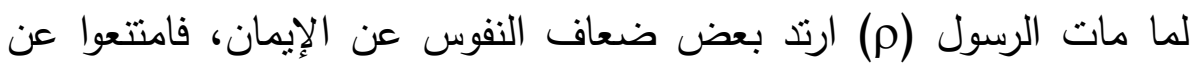

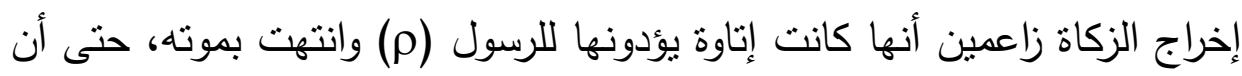
بعضهم أنشد قائلاً:

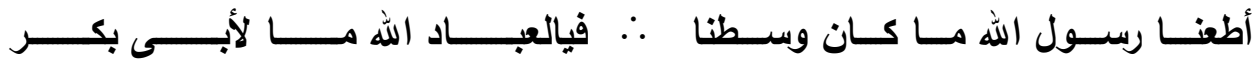

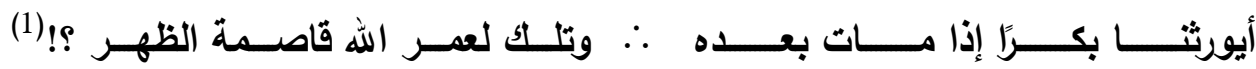

فكان على الصديق (ح) أن يواجه هؤلاء المرتدين بحنكة واقتدار، فجمع

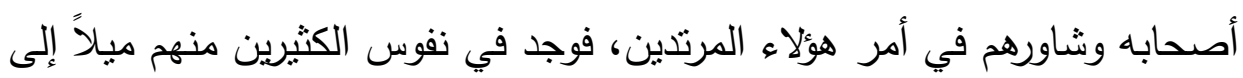

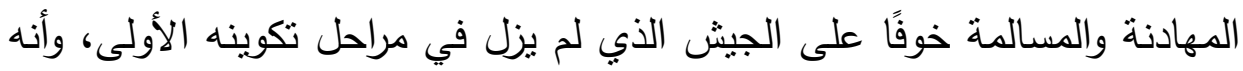

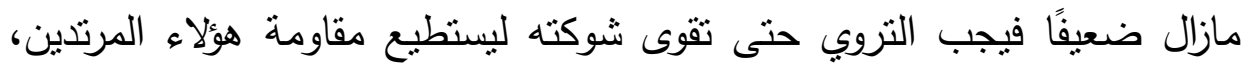

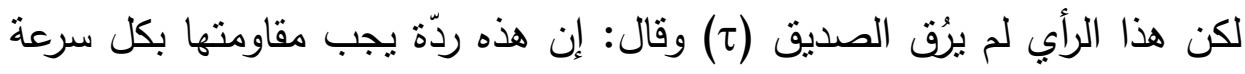

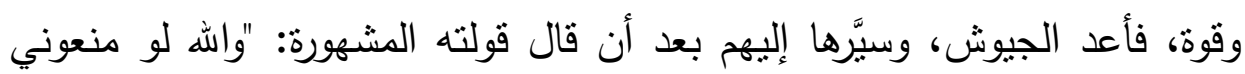

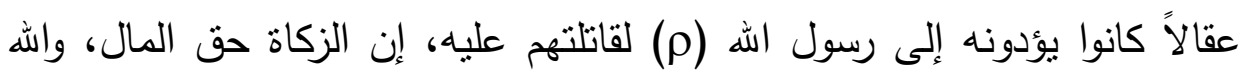

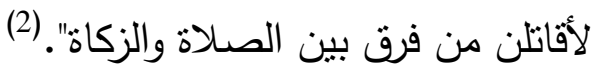

يصور الثاعر كل ذلك قائلاً:

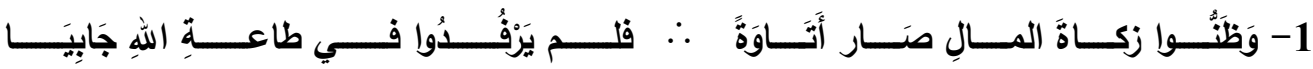

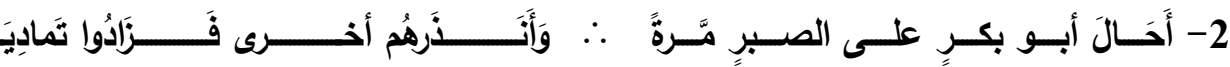

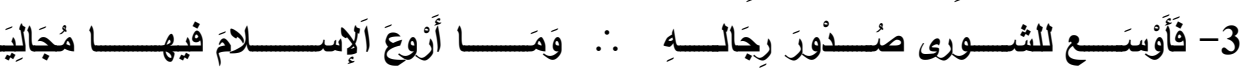




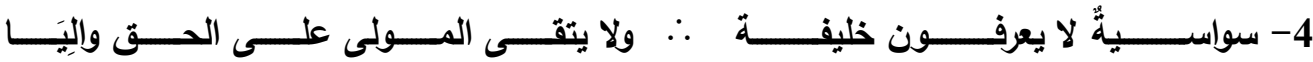

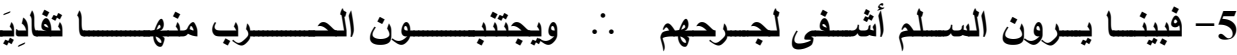

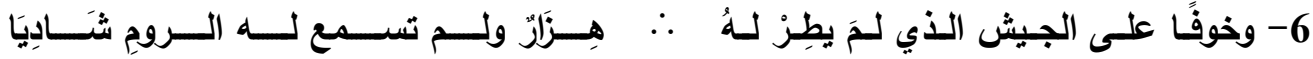

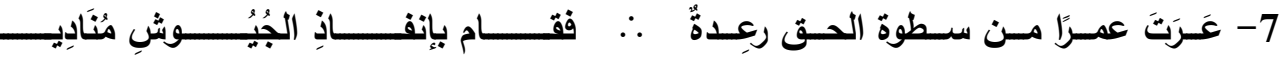

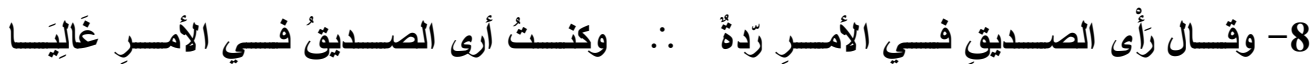

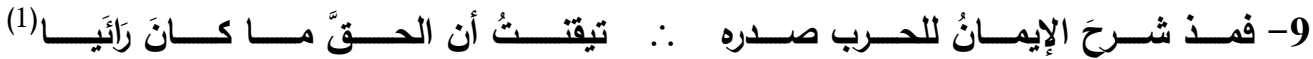

وقد اشتمل البيت السادس من الأبيات السابقة على كنايتين منواليتين تدلان على معنى واحد، هاتان الكنايتان هما: "لم يطر له هزار" و "لم تسمع له الروم شاديا" كناية عن ضعف الجيش وعدم قدرته على مواجهة المرتدين لأنه مازال في هي هري

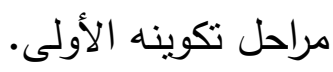
وقد عدل الثاعر عن صريح اللفظ إلى الكناية ليقدم لنا المعنى - ضعف الجيش - مصحوبًا ببرهانه، مشفوعًا بدليله. وهذا لا شك أبلغ في إثباته. وفيها

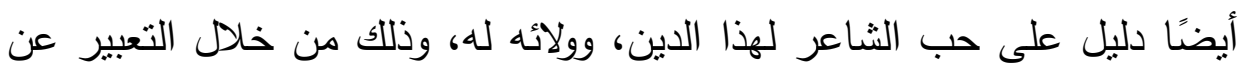
ضعف جيشه عن طريق الكناية تحاثيًا من إلصاقه بالضعف مباشرة عن طريق اللفظ الصريح، وبهذا استحقت الكناية أن تكون "فنَّا بديعًا من فنون البيان، لها أثزها القوي في إثبات المعاني وتأكيدها، وهي تعطي الأديب مجالاً واسعًا للتعبير عن معانيه، وانتقاء الألفاظ الملائمة لها بعيدًا عن العبث والثين والتعرض لما لما لهاب 
يسيء) (1)، كما ضاعف من قيمتها أيضًا عدم الاقتصار فيها على كناية واحدة للتعبير عما يريد، وإنما تأكيدها بكناية نالية تحمل نفس المعنى مما يبالغ في تقرير المعنى، ويدل على براعة الثاعر ، وتمكنه من امتلاك ناصية البيان. اهـ. ثم تتوالى الأبيات بعدما سبق تصور جوانب المعركة، وتصف مدى البلاء الذي أبلاه جيش الإسلام تحت قيادة البطل المغوار خالد بن الوليد (ح) الذي انطلق ومعه الجند بين الأعداء كدوى الرعد، باذلين أقصى الجهد في سبيل إعلاء راية هذا الدين حتى أخضعوا المخالفين، وعادت الأمور إلى ما كانت عليه. يجسد ذلك الأبيات:

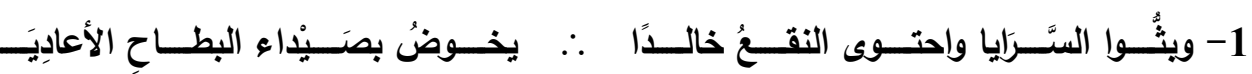

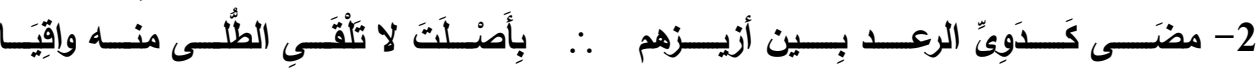

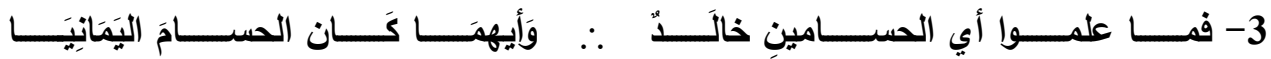

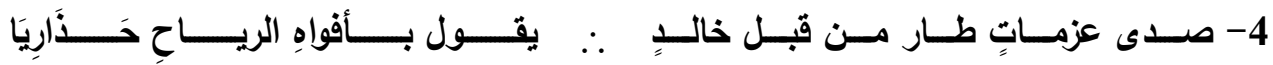

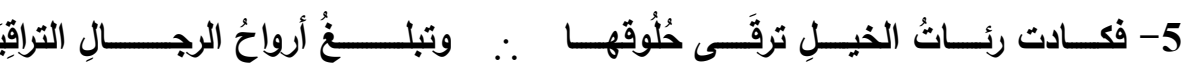

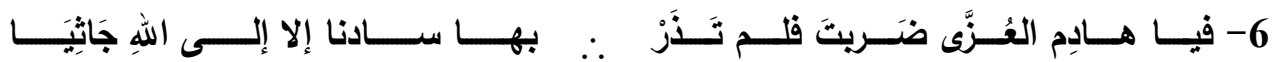

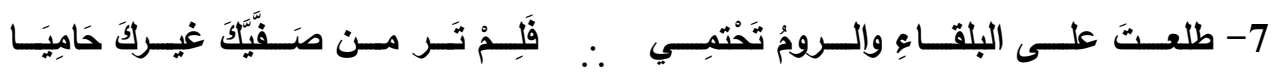

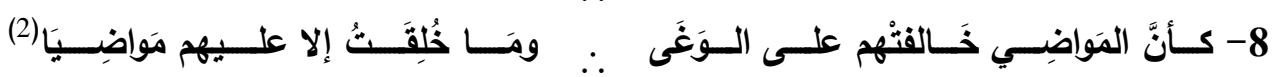
وقد وردت الكناية هنا في عدة مواضع:

$$
\text { (1) أفنان البيان، د/ الثحات أبو سنيت صد(268). }
$$

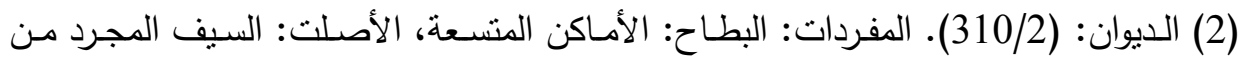

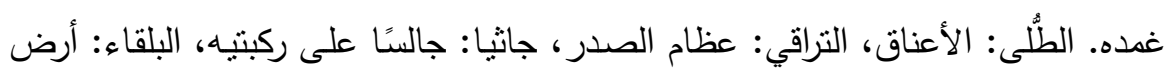
الثام، المواضي: السيوف. 


$$
\text { الأول: في البيت الخامس حيث قوله: }
$$

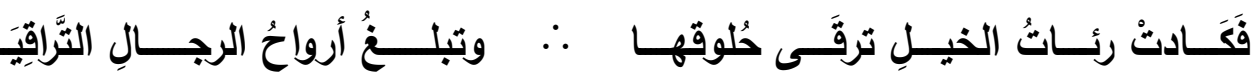

وقد اشتمل كل من شطري البيت على موضع للكناية، فالشطر الأول "فكادت رئات الخيل ترقى حلوقها" كناية عن شدة الجهد والتعب الذي أصاب الخيل بسبب الكر والفر على الأعداء.

ويأني الثطر الثاني "وتبلغ أرواح الرجال التراقيا" كناية عن نفس المعنى الذي دلت عليه الكناية في الشطر الأول. وهما كنايتان عن صفة قريبة لا يمكن معها إرادة المعنى الحقيقي. وهاتان الكنايتان ترسمان بطولة القائد العظيم خالد بن الوليد وجنده، وتصوران مدى الجهد الذي بذلوه في سبيل إخضاع المرندين، ومحو الفتن التي جدَّت بعد الرسول (م)، كما أنهما تجسدان حرص هؤلاء الجنود على الوصول إلى غايتهم مهما كلفهم ذلك من جهر ومشقة في سبيل إعلاء كلمة الله. وضاعف من جمال هاتين الكنايتين الجناس بين (ترقىـ والتراقيا) الذي يربط بين الكنايتين من حيث الثكل منلما بينهما من ترابط من حيث المضمون بدلالتهما على نفس المعنى. كما أن الوصف بالرجال في الكناية الثانية مما يبالغ في شدة التعب وقوة الجهد الذي بذلوه.

وبمعاودة التأمل تتجلى براعة الثاعر في استخدامه للكناية في تصوير كل جوانب المشهد، حيث لم يقتصر التصوير الكنائي هنا على الجند وإنما ظهر أثز الجهد الذي بُنل على كل من الخيل والجند فصور الثاعر المشهدين عن طريق الكناية، وثتتت براعته في تأكيده للتصوير بإيراده مشهدين مختلفين دالين على 
نفس المعنى مما يبرهن على قوة شاعريته، واعتماده على الكناية كدعامة رئيسية في إثبات المعاني وتأكيدها. الثاني: في البيت السادس حيث قوله:

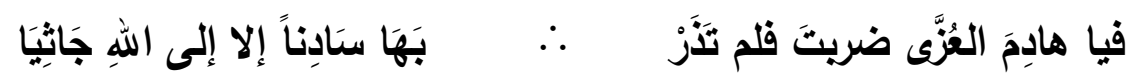
قوله "لم تذر بها سادنا إلا إلى الله جاثيا" كناية عن صفة الخضوع والاستسلام، والثاعر لم يذكر هنذ المعنى صراحة، ولكنه دلف إليه بذكر تركيب يلزم منه هذا المعنى، ومشهذ يدل عليه. كما أن هذه الكناية تصور حالة الذلة والصغار التي أصابت الأعداء وأجبرتهم على الخضوع والاستسلام، كما أنها أيضًا نتير إلى خوفهم وقلقهم. وقد برع الثاعر في اختيار الألفاظ المعبرّة التي تقف بجانب الكناية وصولاً لتحقيق الهدف، من ذلك التعبير بالسادن وهو الكاهن، فإذا كان الكاهن قد حدث منه استسلام وخضوع فأولى بمن تحته أن يكون خضوعهم أثد، واستسلامهم أقوى، ثم التعبير به نكرة دليل على شمولية الخضوع، ثم الإتيان بالصورة عن طريق القصر "إلا إلى الله جاثيا" مما يبالغ في قوة الاستسلام. وفضل الكناية على الحقيقة هنا أنها أوضحت المعنى مشفوعًا بدليله، مصحوبًا ببرهانه، وبالغت في تصوير حالة الذلة التي علت السدنة.

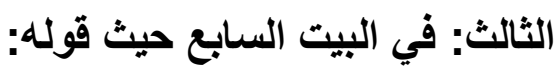

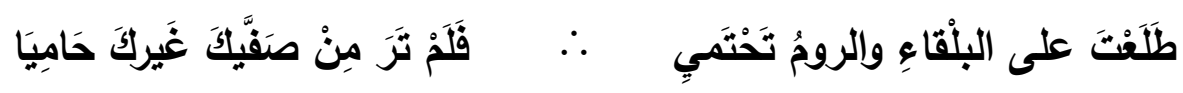
وموطن الكناية قوله: "فلم تر من صفيك غيرك حاميا" كناية عن الهيمنة، وقوة إحكام قبضته عليهم، وإحاطنه بهم من كل الجوانب. 
فإن عدم تمكنهم من الاحتماء بغيره دليل ساطع، وحجة دامعة على هيمنته عليهم، وإحكام قبضته عليهم. وهي كناية عن صفة قريبة لا تتطلب عناءً في استخراجها كما هو شأن معظم الكنايات التي اشتملت عليها البكرية. وترجع بلاغة الكناية هنا في أنها قدمت لنا المعنى - الهيمنة - مصحوبًا ببرهانه ليكون أثبت في النفس، وأقوى في الإدراك، كما أنها صورت المعقول الهيمنة - في صورة محسوسة مبالغة في الإثبات.

وبمعاودة التأمل فيما سبق من كنايات مصورة لموقف الصديق (ح) من المرتدين نجد أن الكناية قد وردت ست مرات في هذا الموقف، وكانت في معظمها كنايات مركزة، حيث جاءت الأربع كنايات الأولى منها في بيتين اشتمل كل بيت على كنايتين منواليتين تدلان على نفس المعنى تأكيدًا للتصوير ، وإمعانًا في تأكيد المعنى، وكلها كنايات عن صفة قريبة لا تحتاج إلى عناء في استخراجها، كما أنها وجدت في كل المواقف التي تعرَّض لها الثاعر في بيانه لهذا الموقف، حيث كان لها دور في بيان موقف بعض الصحابة من خروج الجيش لمحاربة المرتدين وقد تجلى ذلك في الكنايتين الأولتين، وكان لها نفس الدور أيضًا في تصوير الجهد العظيم الذي بذله الجيش بعد خروجه للغزو وهذا ما وضح من خلال الموضعين الثالث والرابع، كذلك لم يغب دورها في وصف نتيجة الحرب من استسلام الأعداء وخضوعهم ورجوعهم إلى الله - تعالى - وهيمنة الجيش وإحكام قبضته عليهم وهذا

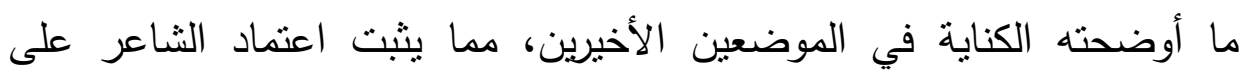
الكناية كركيزة أساسية في نقل المعاني لما تتمتع به من قدرة فائقة على التصوير • 


\section{الكناية في تصوير فِّيته في التعامل مع الرعية}

كان الصديق (ح) خبيرًا بطبيعة العرب، وما هم عليه من منعة وأنفة، فهم إن حسنت معاملتهم صدر منهم الخير الكثير، وإن استشعروا الذلَّ والإساءة انقلبوا أسودًا ضارية تدمر كل ما أمامها، فعاملهم الصديق (ح) من هذا المنطلق باللين والحنو والرحمة، وبهذا استطاع بحنكته وخبرته حسن توظيفهم لخدمة الدعوة، فانضووا تحت لوائه طائعين مخلصين متقانين في نشر كلمة الدين. يصور شاعرنا جانبًا من ذلك حيث يقول:

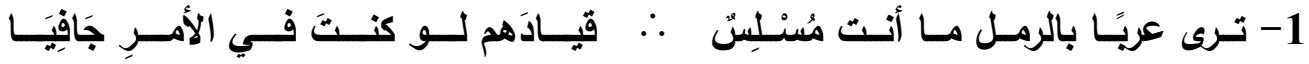

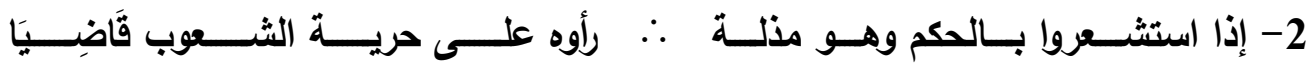

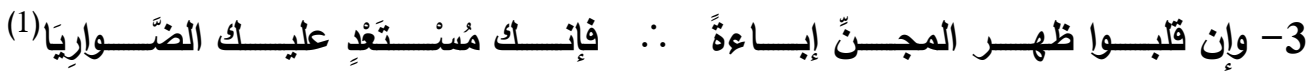

$$
\text { وقد وردت الكناية هنا في موضعين: }
$$

الأول: في البيت الأول حيث قوله: "ما أنت مسلس قيادهم" وسلاسة القياد كناية عن المطاوعة وحسن الانقياد، وهو من صفات الجياد المدرَّبة، وبه تمدح كما قال الحارث بن عباد يصف خيلاً:

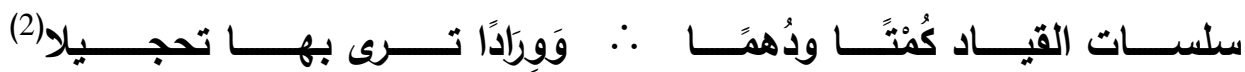
(1) الديوان: (316/2)، المجن: الترس. (2) ينظر : ديـوان الخيل في الجاهلية، جمـع وشـرح وتحقيق دم/ عبد الله سـرحان (216/1)،

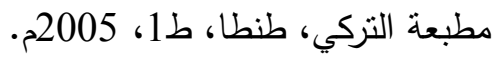


وبالغ من روعة الكناية هنا تولدها عن الاستعارة القائمة على نتبيه العرب

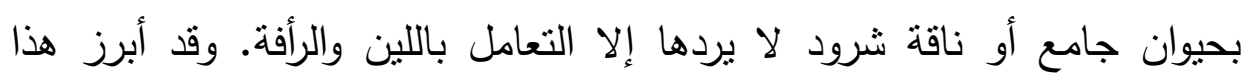

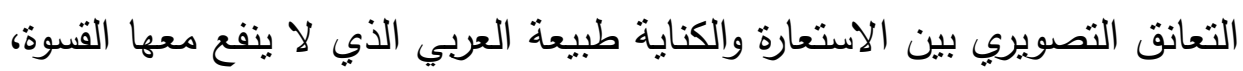

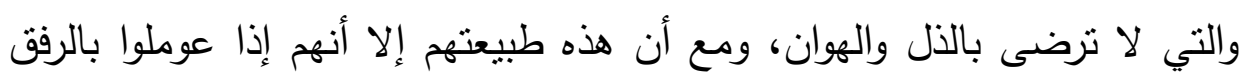
واللين كان منهم الخير الكثير الثاني: قوله في البيت الأخير: "وإن قلبوا ظهر المجن" كناية عن تغير الحال إلى النقيض لأن المعنى الحقيقي لهذا التركيب لا فائدة فيه في هذا المقام إلا لإل بيان أن العرب إن استشعروا بالذل تغير حالهم، وأصبح من الصعوبة لان السيطرة عليهم. وهذا هو المعنى الذي يحجبه التركيب وراءه. وهذه الكناية ليست بعيدة عن الكناية السابقة في إثبات نفس المعنى وهو أن العرب لا يقبلون أبدًا بالذل والهوان، فهم إن استشعروهما تغير حالهم، وانقلبوا أسودًا ضنارية.

وإذا كانت الكناية السابقة قد تعانقت مع الاستعارة تأكيدًا للتصوير ، وإمعانًا في في فاري إبراز المعنى فإن الكناية هنا قد بالغ في روعتها ترشيحها بالتشبيه بعدها "فإنك مستعد عليك الضواريا" لتأكيد التصوير أيضًا، والإمعان في إبراز المقصود. وقد أكدت الكنايتان أنفة العرب، وأنهم لا يقيمون على ضيم، كما أنهما كاشفتان أيضًا عن طبيعة العرب لنشير إلى حسن التعامل معهم، وبإمعان النظر فيما ورد

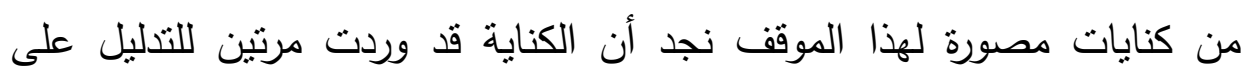
طبيعة العرب، وكان لها من المبالغة ما يعجز التعبير العادي عن تحقيقه، وهي كنايات عن صفة قربية، كما أنها كنايات متتاغية مع السياق، ومتداولة بين

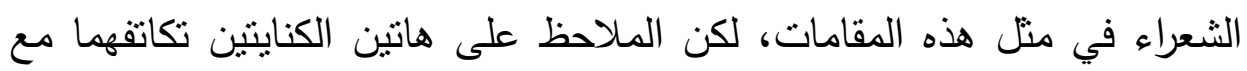
صور بيانية أخرى كالاستعارة في الكناية الأولى، والتشبيه في الكناية الثانية، ولا 
شك أن ذلك أدخل في المبالغة، وأقوى في التصوير، فالثاعر بهاتين الكنايتين البديعيتين قد أبرز المعنى المقصود - طبيعة العرب - وأظهره في صورة حسية، وبذللك اتضحت الصورة تمام الوضوح حتى لم يعد للنفس تشوف إلى المزيد. 


\section{الكناية في تصوير ما فعله خالد بن الوليد في}

\section{موقعة اليرموك تحث قيادة الصديث (ح)}

في العام الثالث عشر للهجرة أعد الإمبراطور البيزنطي "هرقل" جيشًا كبيرًا قوامه مائة ألف مقاتل، ووجهه نحو الجنوب للقضاء على دولة الإسـام، فجهَّز الخليفة هئة

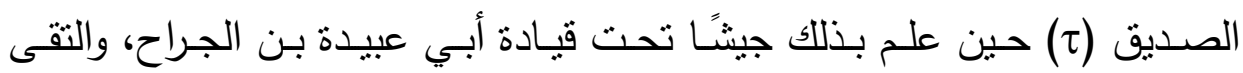

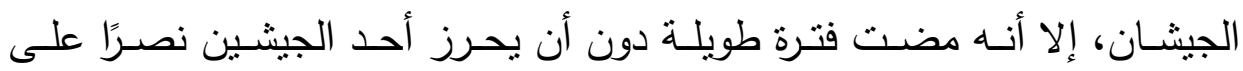

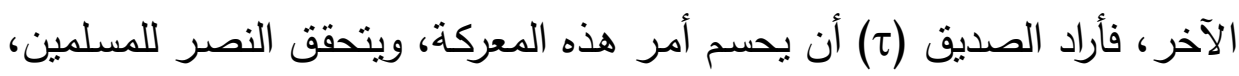
فأرسل إلى خالد بن الوليد (ح) بخبرته على كل هذه الصعاب، حيث أمر الجند بإظماء الإبل عدة أيام، ثم أوردها الماء بعد ذلك فثربت كثيرًا، ثم أمر الجند بربط مشافر الإبل حتى لا تجتر فيتسرب منها الماء، فكان ينحر لجنوده منها ليأكلوا وبستقرغون الماء منها ليشربوا، وبذلك يحصلون على الطعام والثراب حتى نجا بهذه الطريقة العبقرية، وانضم إلى جيش المسلمين. يصور الثاعر هذا المشهد قائلاً:

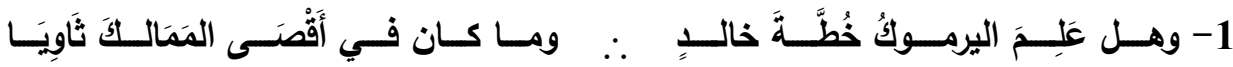

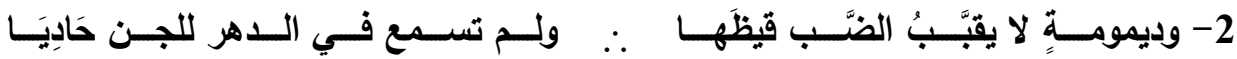

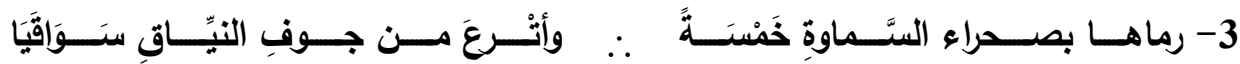

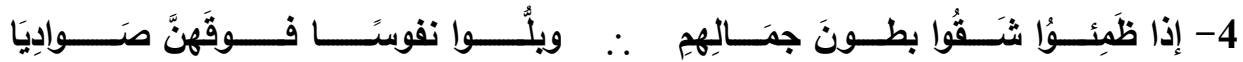

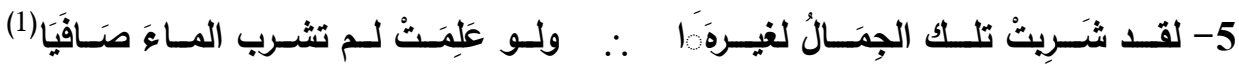


والأبيات تتحدث عن مدى الثدة والمعاناة التي لاقاها خالد بن الوليد (ح) ومن معه من الجنود في بادية السماوة وما تتسم بـه من وعورة في سبيل اللحاق بجيش المسلمين في الثام.

وقد أتى الثـاعر بثلاتثة قرائن للتدليل على هذه الثدة، هذه القرائن متمنلة في

$$
\text { الكناية حيث وردت ثلاث مرات: }
$$

الأولى: قوله في البيت الثاني: "وديمومة لا يقبب الضب قيظها" كناية عن الثدة والمعاناة التي يلقاها من بمر بها، والمعنى الحقيقي لهذا التركيب أن شدة الحر في هذه الصـحراء لا تسـمح للضـب ببنـاء قبـة فيها، ولكن عين الثاعر ترنو إلى ما وراء هذا اللفظ من تصوير شدة المعاناة التي لاقاهـاء هاء هاء الجيش في سبيل اللحاق بإخوانهم. وهي كناية عن صفة بعيدة يتوصل إلى المعنى الكنائي بعدة وسائط، حيث إن وصفها بهذا الوصف يستلزم وحشتها ووعورتها، وهذا يستلزم معاناة من بمر بها. الثانية: في الثطر الثاني من نفس البيت حيث قوله: "ولم تسمع في الدهر للجن حاديا" كناية عن نفس المعنى التي تضمنته الكناية السابقة، وهي كناية

بعيدة تعتمد على نفس الوسائط التي اعتمدت عليها الكناية السابقة. الثالثة: قوله في البيت الرابع: "إذا ظمئوا شقوا بطون جمالهم" كناية عن الثدة أيضًا، فإن من يشت بطن جمله ليشرب دليل دامـغ على شدة حاجته ومعاناته، وهذا دليل ثالث يضـاف إلى مـا سبق من أدلة لتأكيد شدة المعاناة التي لاقاها الجيش في بادية السماوة. وبالتأمل فيما سبق من كنايات مصورة لهذا الموقف يتضـح أنها تكاتقت كلها لبيان معنى واحد هو الثدة التي لاقاها الجيش، وكلها كنايات عن صفة والمعنى الحقيقي لهذه الكنايـات مقصـود بجانب المعنى الكنائي وهو ممـا يزيد في ثراء 


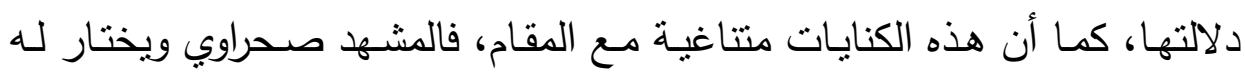

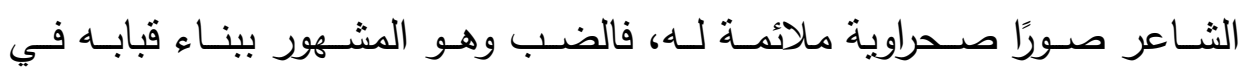
الصحاري والفلوات رغم كل ما فيها لا يستطيع ولا يمكنه فى هذه الفلاة أن يقيم

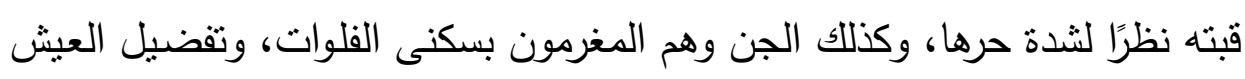

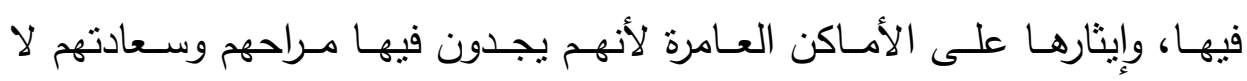

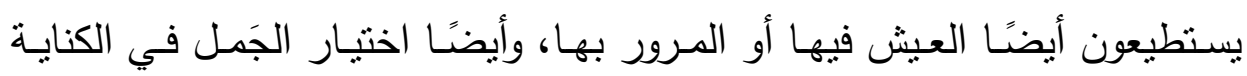

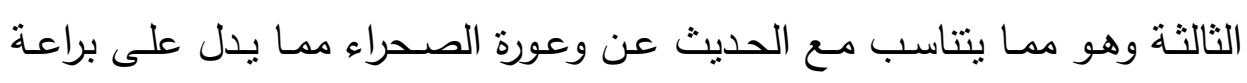
الثاعر في اختيار المشاهد الدالة على المعنى المتتاسقة مع المقام. وبهذه الطريقة كثف الثاعر عن شدة المعاناة التي لاقاها سيف الله المسلول

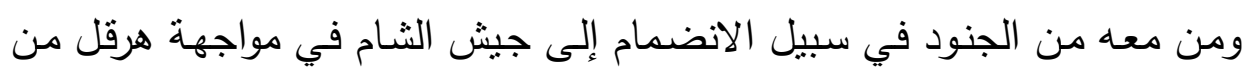

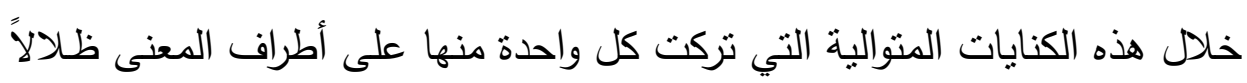

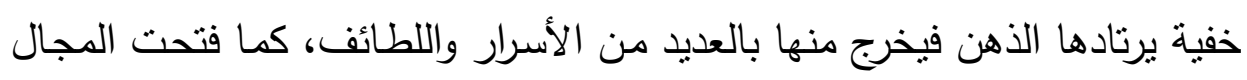

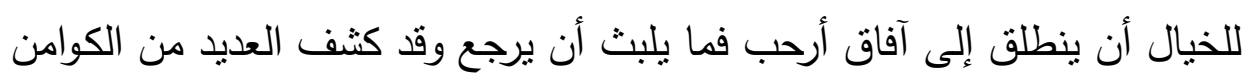

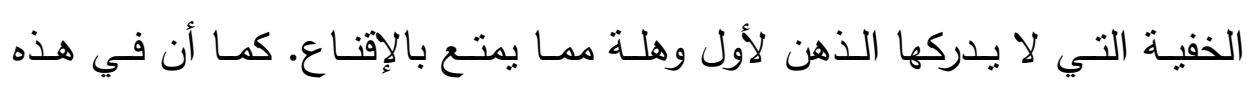

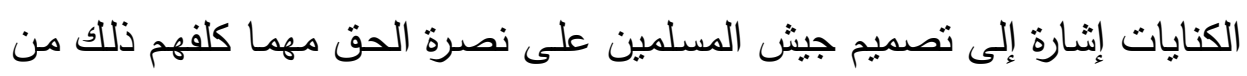
مشقة. 


\section{الكناية في تصوير تواضعه (ح)}

لعلَّ من نافلة القول أن يقال: إن من أبرز الصفات التي تميز بها الصديق (ح) صفة التواضـ، ولا غرو فهو الذي صـاحب النبي (م) في مواقف كثيرة، فانطلت عليـه صـفاته ومـن أبرزهـا صـفة التواضـع رغم أنـهـ الصديق، وأنـه الخليفـة الأول للمسلمين.

وقد بلغ من تواضعه (ح) أنه لم يكن في سياسته للرعية جافيًا ولا قاسيًا ولا زاهيًا شأن معظم الحكام، حتى إنه حين تولى الخلافة لم تتغير مظاهر حياته فكان بسير بين الرعية بثيابه البالية، ولم يتخذ الخدم والحشم، وكان في بداية ولايته يذهب إلى إلى السـوق ويباشـر التجارة لولا أن الصـحابة - رضـوان الله عليهح - راجعوه في هذا الأمـر، وكان رده عليهم: إنها يسعى على أهله وعياله فإن أضـاعهم كان للرعيـة أضيع. يعرض الثاعر صورًا من تواضعه (ح) فيقول:

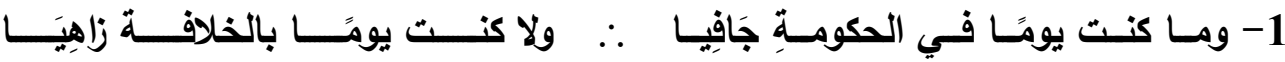

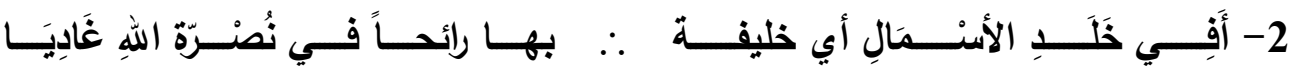

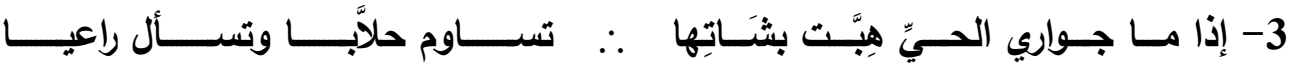

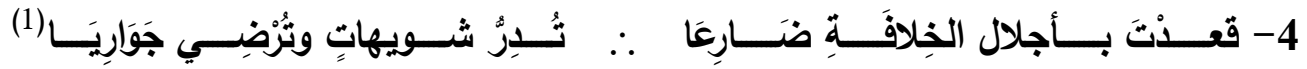
والأبيات تركز على تأكيد صفة نواضع الصديق (ح) ولذلك كان للكناية دورها الرائد في التدليل على تواضعه حيث وردت في عدة مواضع: 
الأول: قوله في الييت الأول: "ولا كنت يومًا في الخلافة زاهيا" كناية عن صفة

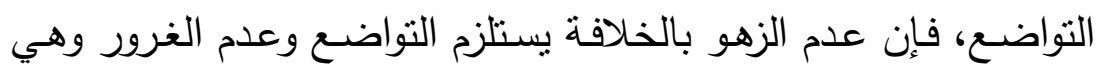
كناية قريبة لا تحتاج عناء في استخراجها.

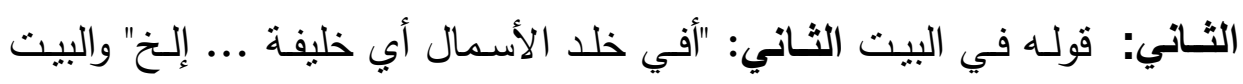

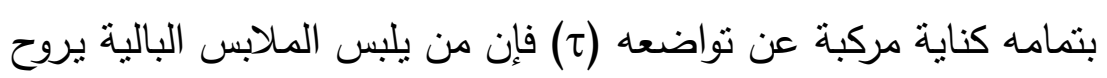

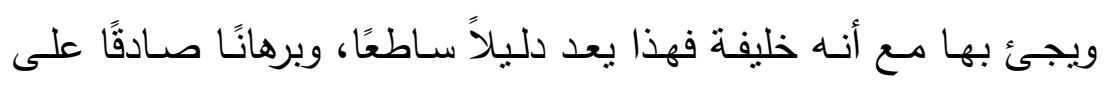
تواضعه.

وضاعف من جمال الكناية هنا ورودها في سياق الاستفهام الإنكاري المفتتح به

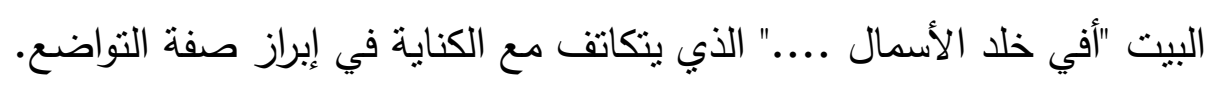
الثالث: قوله في البيت الأخير:

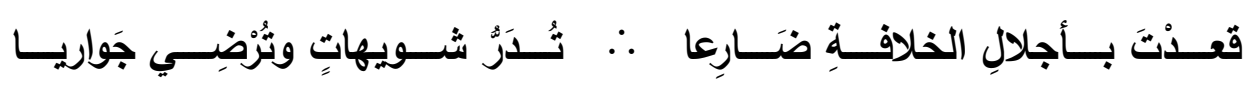

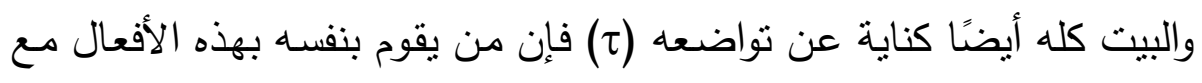

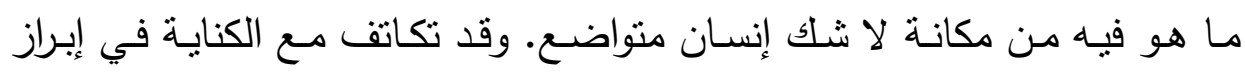

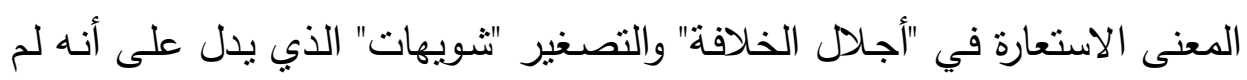

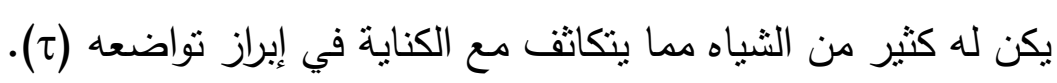

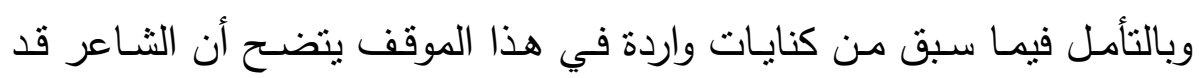

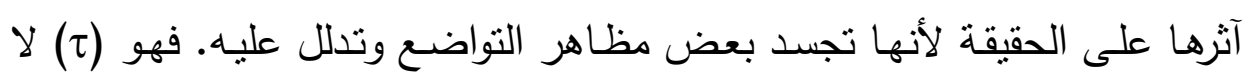

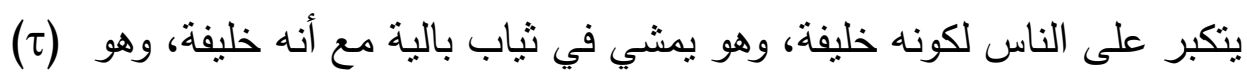

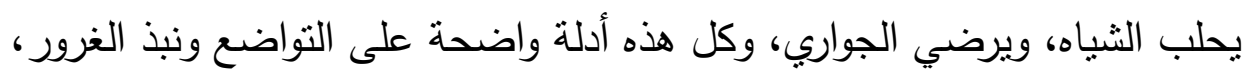

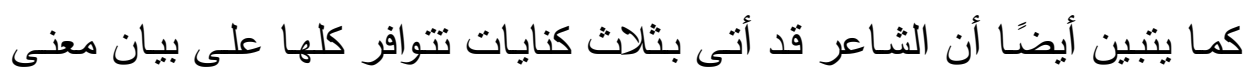


واحـد - التواضــع - ليحـيط بالصـورة مـن جميـع جوانبهـا مبالغـة في المعنىى، واستقصاءً في الوصف، كما أنها أيضًا كلها كنايات مركبة استغرق معظمها بيتًا بأكمله، والكنايات المركبة بطبيعتها أقوى من المفردة لاحتياجها إلى إعمال الفكر للوقوف عليها. كما أن هذه الكنايات يصـح أن تتطبق على أي خليفة بهذه الأوصاف في كل

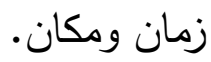




\section{الكناية في تصوير الاقتداء به (c)}

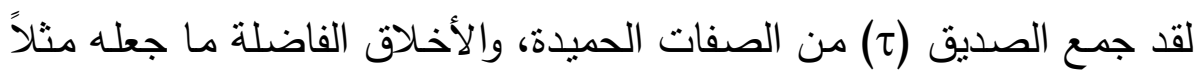
يحتذى به، ولو تصفحنا سيرته (ح) لوجدناها تكتظ بالمواقف المشرقة التي تصور تأثز الناس - بكل طبقاتهم - واقتدائهم به (ح)، ونظرًا لكثرة هذه المواقف التي هي أكثر مـن أن تحصسى، يسلط شـاعرنا الضـوء على موقف واحد من مواقف هذا

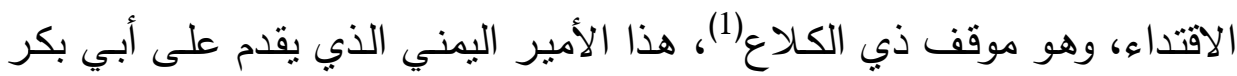
الصديق (ح) في المدينة في زينته يحوطه الخدم والحشم - كثأن أي أمير - فإذا بـه يفاجأ بخليفة المسلمين يرتدي ثيابًا عاديـة، وليس عليه شيء من آثار الملك يفرق بينه وبين الرعية، فتأثز الرجل بالصديق (ح) وأقر للإسـلام بأنه دين المساواة،

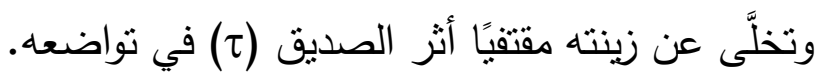
يجسد الشاعر هذا المشهد قائلاً:

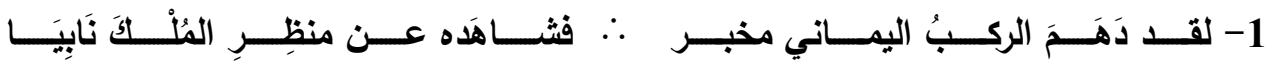

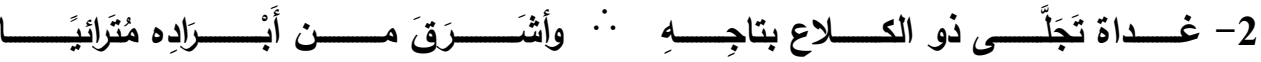

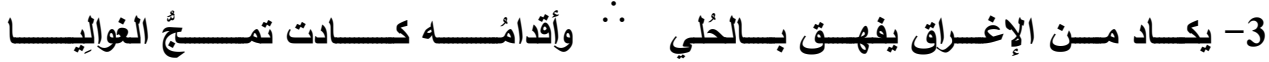

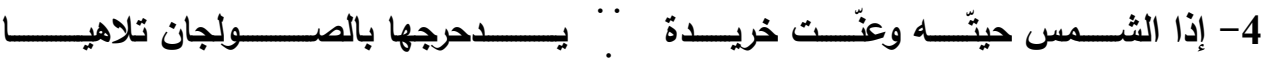

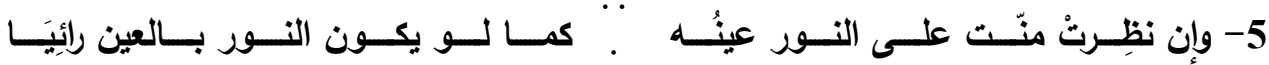

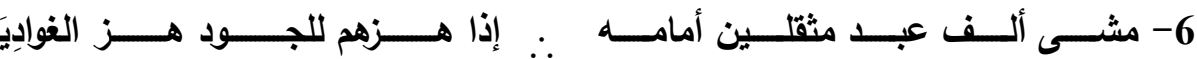

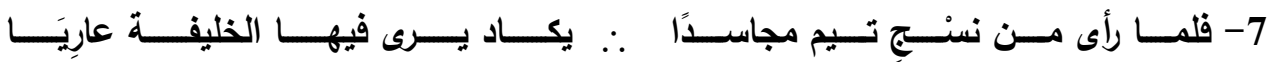

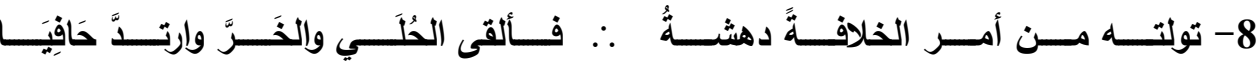

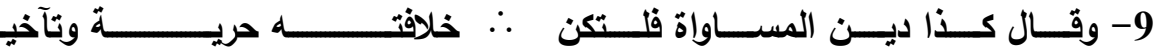

(1) ذو الكلاع اليمني: من أمراء اليمن، أسلم وأقبل على أبي بكر (ح) في المدينة. 


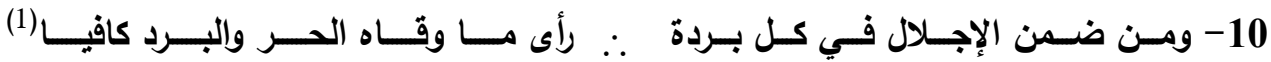

والأبيات تصور المشهد بتمامه من وقت مقدم ذي الكلاع في أبهته وزينته إلى وقت خروجـه في تواضـع وإخبـات، كمـا أنها تعرض حالتين مختلفتين متقـابلتين لموصوف واحد هو ذو الكلاع: الحالـة الأولى: حالة الأبهة والزينـة التي تحلى بها ذو الكلاع عند مقدمه وهذه تولت بيانها الأبيات الستة الأولى، وقد احتشد الثـاعر لإيضاحها معظم صور البيان ومن أكثرها الكناية حيث ورد في عدة مواطن. الموطن الأول: في البيت الثالث حيث قوله:

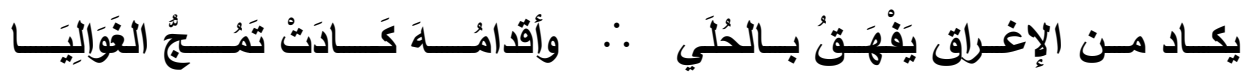
وقد اشتمل هذا البيت على كنايتين تدلان على نفس المعنى هما قوله: "يفهق بالحلي" وقوله: "وأقدامه كادت تمج الغواليا" كنايتان عن العظمة والأبهة، وحين أراد الثـاعر التعبير عن هذه المعاني سـلك طريق الكناية ليقدم لنا المعنى مصحوبًا بدليله، مشفوعًا ببرهانه، فعدل عن ذكرها صراحة إلى أنه يفهق بالحلي، وأن أقدامه كادت تمـج الغواليا لينتقل الذهن منهما إلى كثرة مـا يلبسـه سواء في أعلاه أو في أسفله. ثم ينتقل من ذلك إلى عظمته وأبهته، وهي كناية بعيدة كما ترى. وإذا كان

(1) الديوان: (319/2، 320)، نمج: يقال: مج الثراب والثيء من فيه - يمجه مجا، ومـج به:

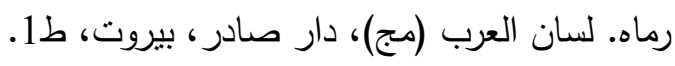


هذا شأن الأعلى والأسفل فما بينهما لا شك آخذ نفس الصفات التي يتصف بها الأطراف.

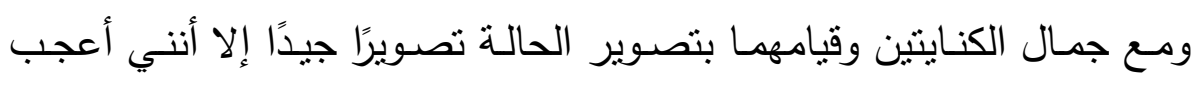

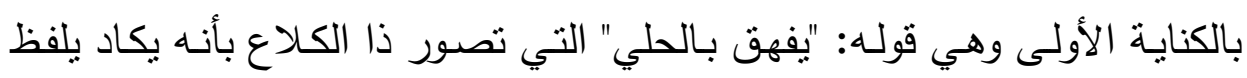

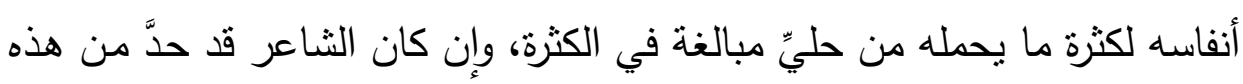

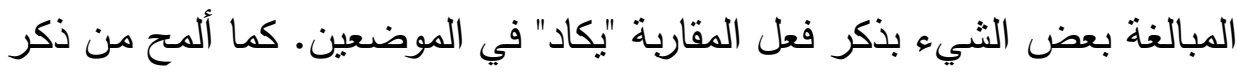

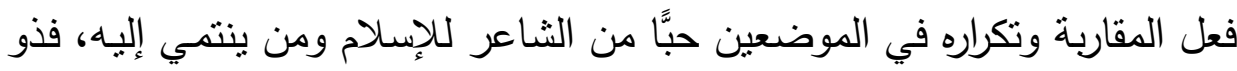

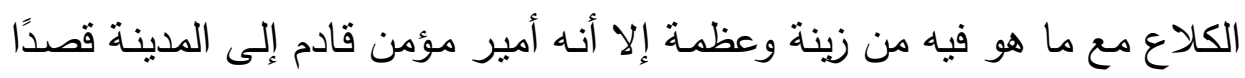

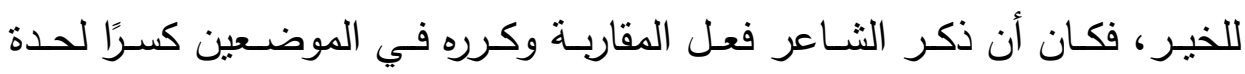
المبالغة.

الموطن الثاني: في البيت الثالث حيث قوله:

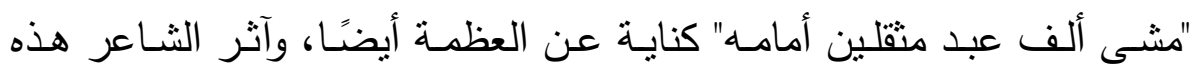

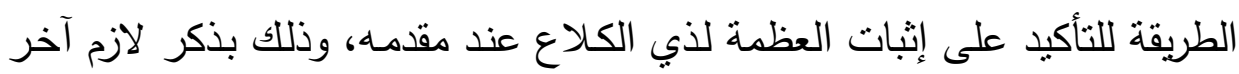

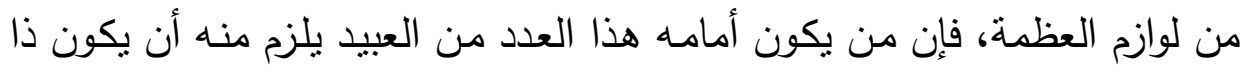
عظمة وأبهة، وهذا دليل آخر يضاف إلى ما سبق من من أدلة.

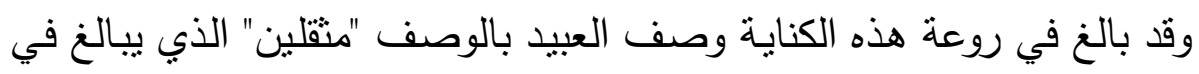

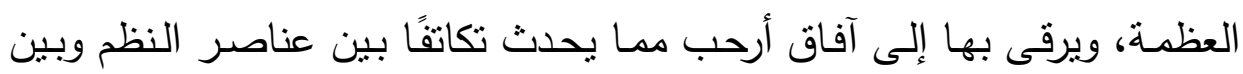

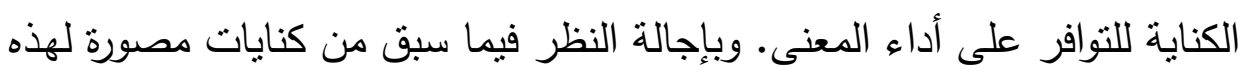

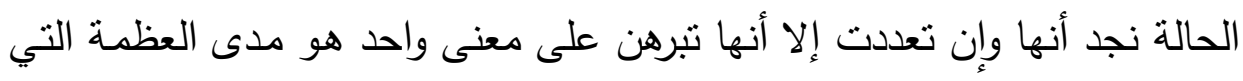
كان فيها ذو الكلاع، ولكن الثناعر لم يكتف بيرهان واحد للتندليل على ذلى ذلك، وإنها جاء بأدلة مختلفة كلها نافذة إلى المعنى المقصود ودالة الكاعلة عليه، فمرة تدرك العظمة من خلال روية ذب الكلاع وهو يفهق بالحلي فيقودنا هذا إلى العظمة والزينة، وتارة 
ندرك العظمة من خلال أن أقدامه كادت تمـج الغواليا، وأحيانًا ندرك العظمة من خلال رؤيتتا لمشهد هذا الجيش من العبيد الذين يتقدمونه كما يفعل مع ذي المكانة العالية، وبذللك استطاع الثـاعر أن يلتقط لنا الصـورة من جوانب متعددة تأكيدًا للتصوير ، وإمعانًا في إبراز المعنى، وهذا مما يدل على شـاعرية فذة، وقدم في الثعر راسخة.

الحالة الثانيـة: حالة التواضـع والزهد التي اعترت ذا الكـلاع بعدما شـاهد تواضـع الصـديق (ح) وزهده، وهذه الحالـة تولت بيانها الأبيات الأربعـة

المتبقية.

وكما تألقت الكناية في تصوير الحالة الأولى تألقت أيضًا في تصوير ما يقابلها في هذه الحالـة، فكمـا اثـتمل البيت الثالث مـن الأبيـات السـابقة على كنايتين تصوران العظمة التي اتصف بها ذو الكلاع عند مقدمه، يشتمل البيت الثامن وهو قوله:

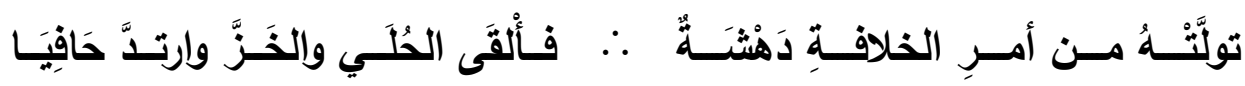

على كنايتين أيضًا تقابلان الكنايتين السـابقتين، فقولهـ: "فألقى الحلي والخز " كناية عن التواضع والزهد، وقوله "ارتد حافيا" كناية عن نفس المعنى أيضًا، وهما كنايتان مقابلتان للكنايتين "يفهق بالحلي" و "أقدامه كادت تمج الغواليا" في تصوير

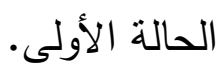

ولنا أن نلحظ ما وراء إلقاء الحلي والخز والمشي حافيًا من زهد وتواضـع جعل هذا الملك المعظم المدجّج بشتى أنواع الزينة يلقي زينته في غير تفكير ولا روية. 
ومن ينأمل يجد أن المعنى الحقيقي هنا مراد بجانب المعنى الكنائي وهو مما يعطي الكناية قوة.

ولنا أن نتأمل براعة الثـاعر في تتسيقه بين الكنايات في كلتا الحالتين، فإذا

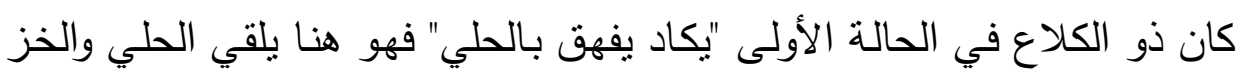

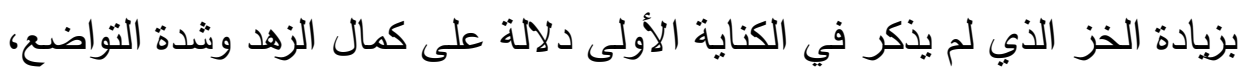

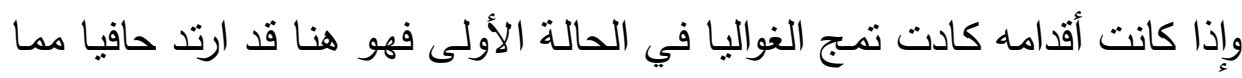
يجعل المنلقي يدرك ما بين الحالتين من تتاقض تام.

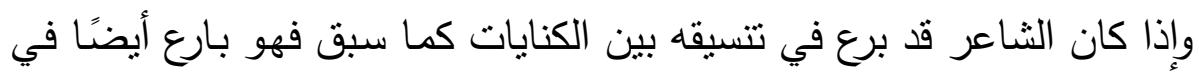

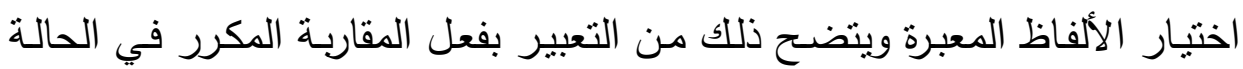

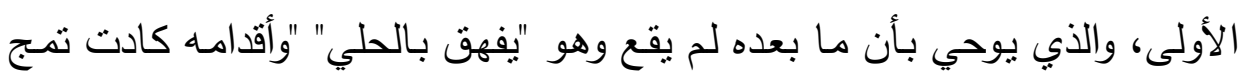

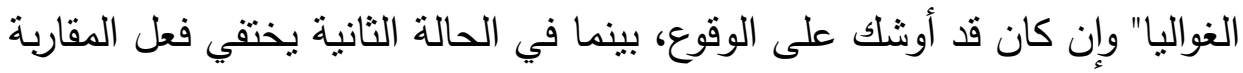

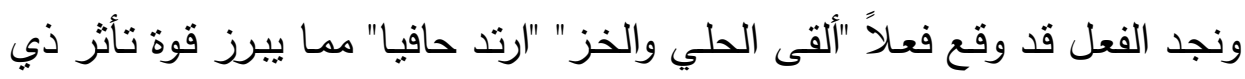

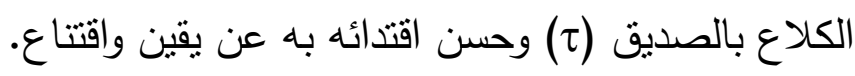

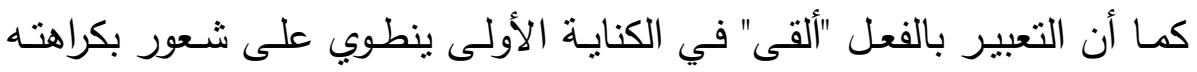

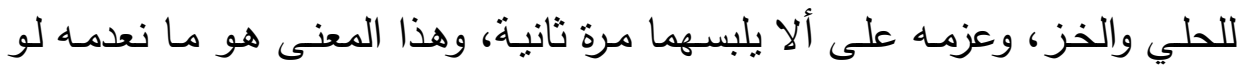

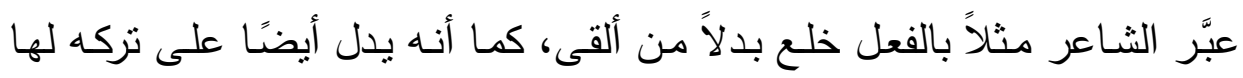

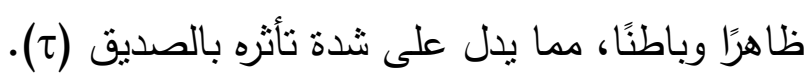

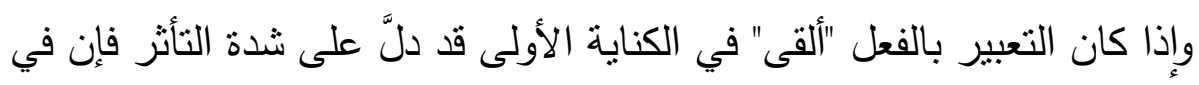

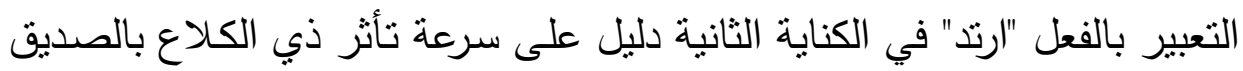

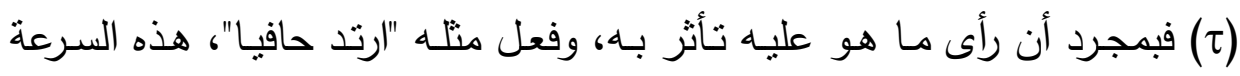

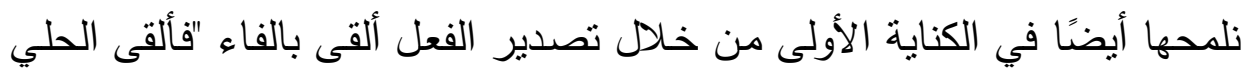


والخز" مما يبرز براعة الثـاعر في اختيار كناياته المصورة، وفي اختياره للصورة التركيبية التي تأتي عليها مما يبالغ في جمال التصوير الكنائي وروعته. 


\section{الكناية في تصوير أسبقيته إلى الخير}

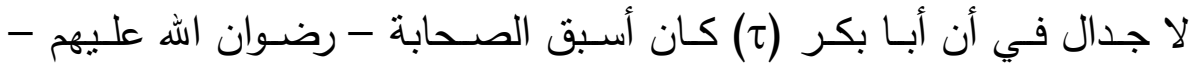

وأطولهم يدًا في شتى وجوه الخير فلم يسبقه أحد، وخير شـاهد على ذلك القصـة المشهورة لهذه المرأة العجوز العمياء التي أضناها السقم وليس لها عائل، ولما علم

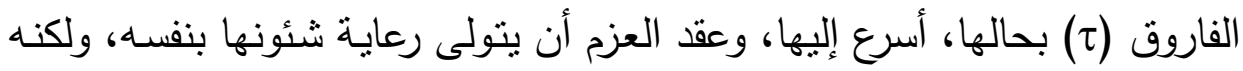
عندما وصل إليها وجد أنها لم ينقصها شيء، فيتعجب، ويتساءل: من الذي سبقني إلى هذا الفضل !؟ فتجيبه المرأة بأنها عمياء لا تعرف من هذا الرجل الذي يأتيها

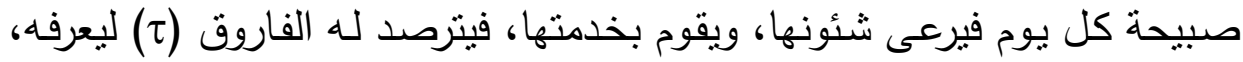
فإذا به الصديق (ح)، وحينئذ يقر الفاروق بأسبقية الصديق (ح) إلى كل خير قائلاً: "ما سبقت أبا بكر إلى خير إلا سبقني إليه". يصور الثاعر هذا الموقف قائلاً:

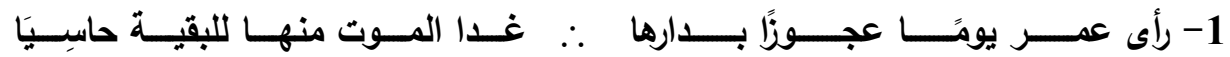

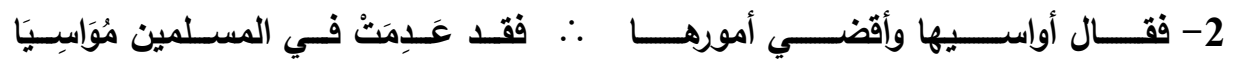

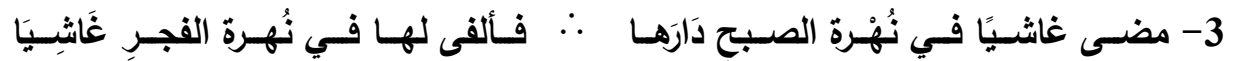

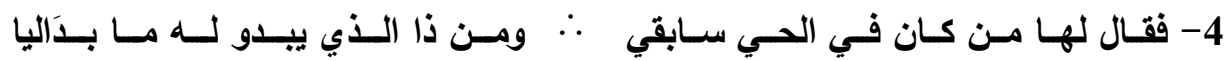

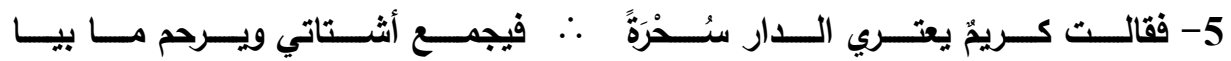

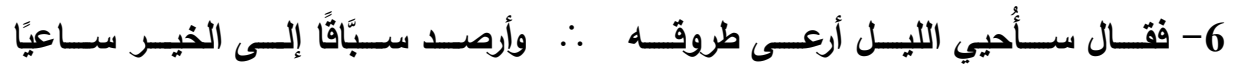

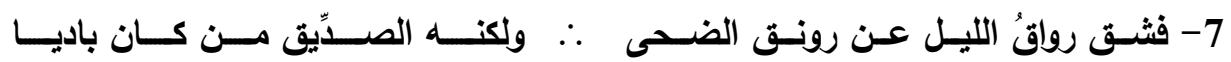

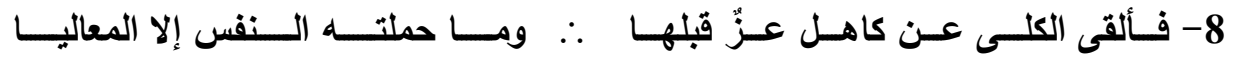

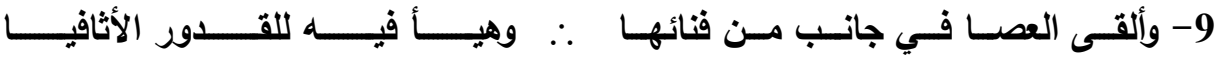
10- فصــاح بـه الفـاروق مـا كـان ســابقي .

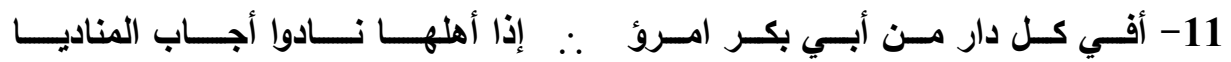




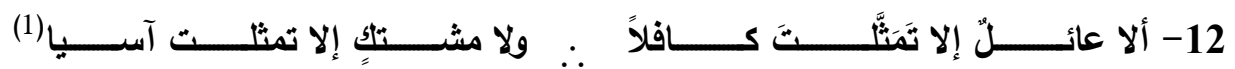

$$
\begin{aligned}
& \text { وقد وردت الكناية هنا في موضعين: } \\
& \text { الأول: في البيت الأول حيث قوله: }
\end{aligned}
$$

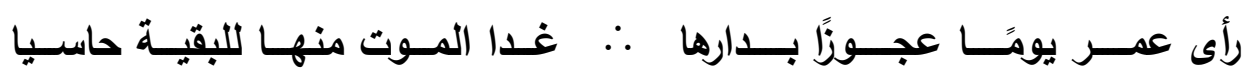

والثطر الثاني من هذا البيت "غدا الموت منها للبقية حاسيا" وإن كان التصوير الاستعاري فيه بارزًا بصورة واضحة، إلا أنه يحمل من وراء التركيب كناية عن شدة ضعف هذه المرأة، مما يظهر حاجتها إلى من يقوم بشئونها.

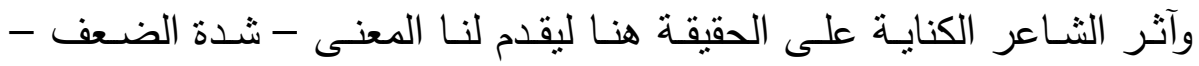
مصحوبًا بدليله، مقرونًا ببرهانه، وهذا هو مكمن الأبلغية في هذه الكناية. وبالتأمل في هذه الكناية نجد أنها فضلاً عما تبرهن عليه من شدة حاجة هذه المرأة إلى من يعولها فإنها تشير أيضًا إلى أن من كانت هذه حالتها فهي بعيدة عن الأنظار قلما يلتفت إليها أحد، حيث لا تستطيع حتى الإعلان عن حاجتها،

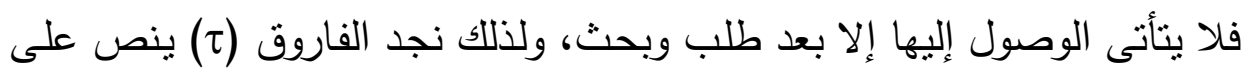
ذلك في البيت التالي مباشرة حيث قوله:

الديوان: (321/2، 322)، المفردات: نهـرة الصبح: أول وقته، الكلى: جمـع كلية وهي القربة التي يحمل فيها الماء، الأثافي: القدور • 


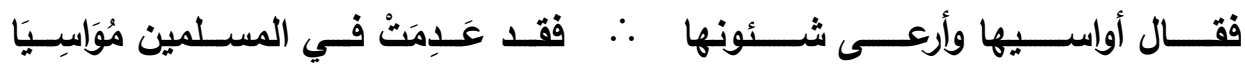

ومع ذلك وصل الصديق (ح) إليها، وأدرك شدة حاجتها، وقدم لها ما تحتاجه، مما يؤكد طول باعه (ح) في وجوه الخير ، ووصوله فيه إلى درجة لم يصلها أحد، وتتقيبه عنه مهما كلفه ذلك من شدة ومشقة. وحين نتأمسل البنـاء التركيبي لهذه الكنايـة تتضـح لنا براعة الثـاعر في إتيانـه بالمسند "غدا" الذي يدل على أن الهلاك قد بادرها وافترسها مبكرًا وقضى عليها، ثم إتيانه بالمسند إليه "الموت" هذا اللفظ المفجع الذي لا يمكن الفرار من قبضته مما

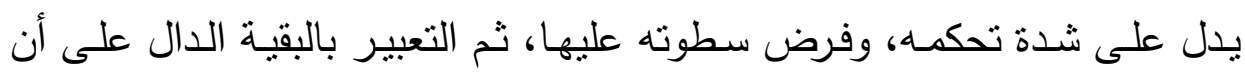
الموت قد دب فيها فعلاً، وأتى على أكثرها حتى لم ييق منها إلا فتات يسير ولذلك بـانك

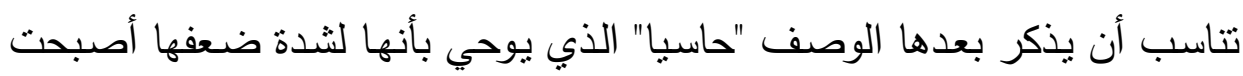

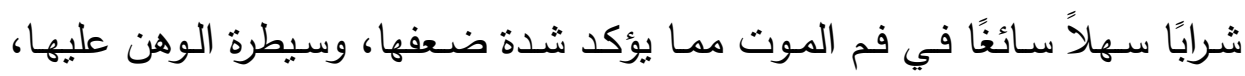
فالثـاعر تأنق في اختيـار الألفاظ وسبكها ليكون التركيب معبرًا عن حالة هذه المرأة، وبهذا تآزرت الكناية مع بنائها التركيبي للقيام بتصوير حالة هذه المرأة خير

$$
\text { تصوير ، وإبرازها في صورة يأسى لها كل من يشاهدها. }
$$

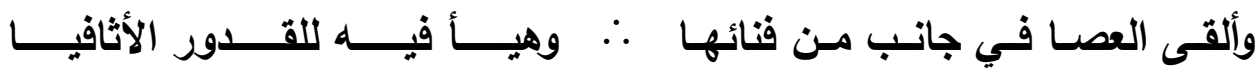

قوله: "وألقى العصا" كناية عن التهيؤ لخدمتها، والاستعداد لرعاية شئونها؛ لأن إلقاء العصا لازم من لوازم الاستعداد لفعل شيء ما. 
ويلاحظ هنا أن المكني به حسي والمكني عنه معنوي مما يصور المعقول في صورة محسوسة فيجعله يرسخ في الأذهان، فيتأكد المعنى. وقد أبرزت هذه الكناية

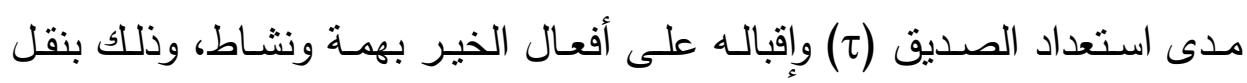

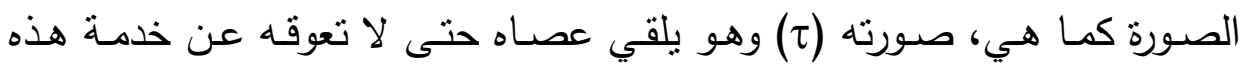
المرأة مما يبرهن على شدة إخلاصه، وحبه لعمل الخير . وبالتأمل يتبين أن الثـاعر قد أبى إلا أن يثبت للصديق (ح) كمال الاستعداد، وشدة الإخلاص وذلك بالنص على أن العصا في جانب من فنائها حتى لا تعيقه في أثناء قيامه على خدمتها ذهابًا وإيابًا مما يؤكد كمال التجرد، وشدة التهيؤ . 


\section{الكناية في تصوير حاله يوم وفاته}

لقد ضرب الصديق (ح) المتل الأعلى في الزهد، والعمل للآخرة، حيث فارق

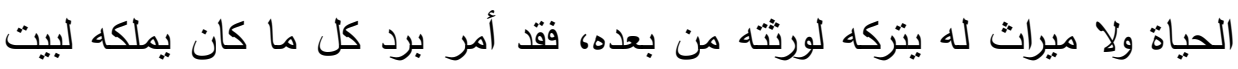

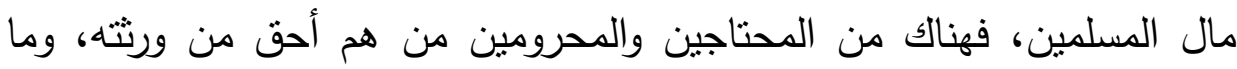

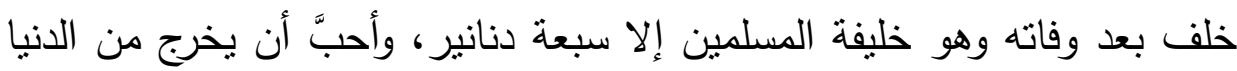
معافى لا له ولا عليه. - مليه

بعبر الثاعر عن ذلك قائلاً:

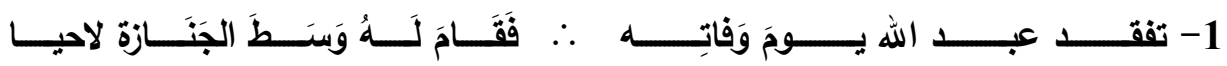

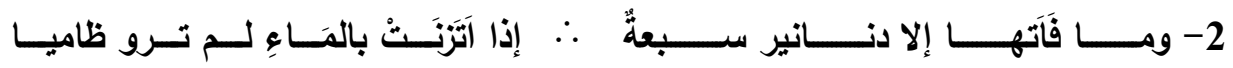

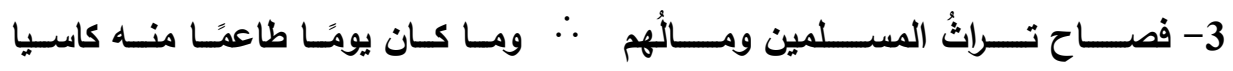

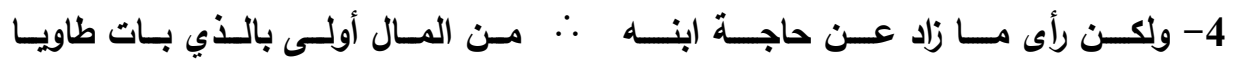

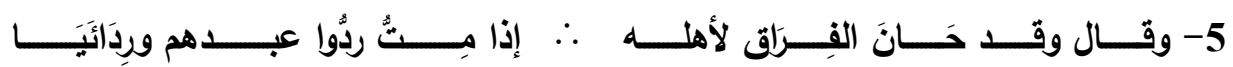

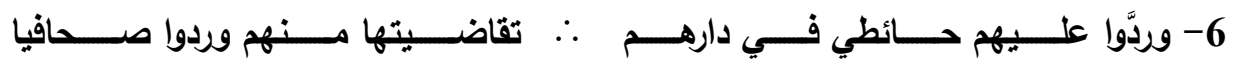

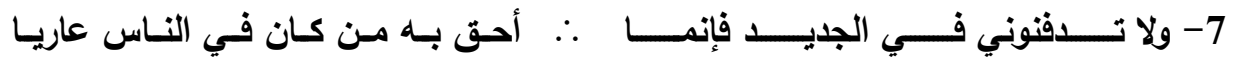

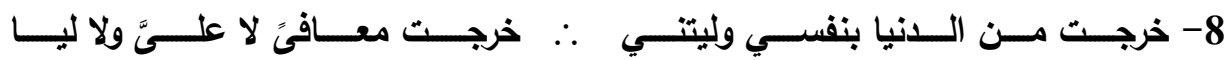

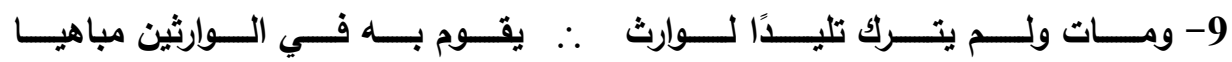

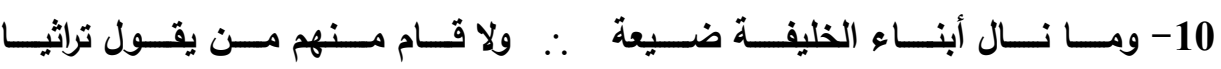

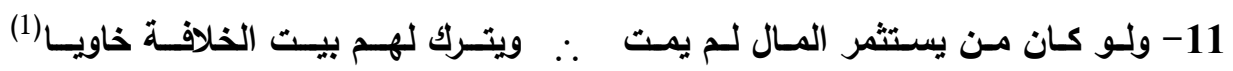


وقد سلكت الأبيات طريقة واضحة في التعبير عن معانيها، فجاءت ألفاظها عادية مجردة معتمدة طريقة السرد القريب من الكلام العادي، ومع ذلك لم تخل من الكناية، ففي البيت الثاني يطالعنا قوله:

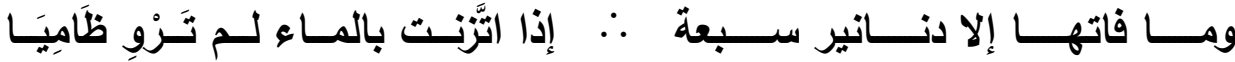

فقوله: "إذا اتزنت بالماء لم ترو ظاميا" كناية عن قلتها وعدم نفعها. والثاعر لم يذهب مباشرة إلى هذا المعنى، ولكنه توصل إليه بذكر تركيب يلزم منه هذا المعنى الكنائي، ولا شك أن ذلك أبلغ وأقوى في إثباته مما لو جاء به غفلاً ساذجًا بادئ الأمر، هذا فضلاً عما فيه من تصوير للمعنى بإقامة الدليل عليه وفي هذا نأكيد

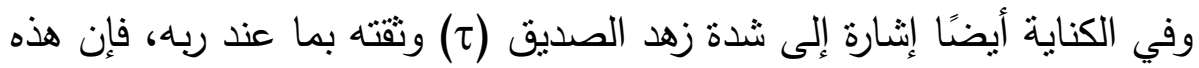
الدنانير السبعة التي تركها لا تعد في عُرف التركات مالا، ولا تؤدي الغرض

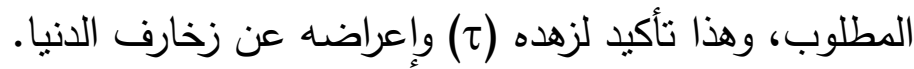

واصطفاء التعبير بوصف الظمأ دون العطش منتاسب جدًا هنا مع السياق، وذللك لأن القليل من الماء قد يذهب الوصف بالظمأ وإن ظل العطش قائمًا، ذلك فإن هذه الدنانير لو وزنت بالماء لما كانت قادرة على إزالة الظمأ فضلاً عن لهن العطش مما يبالغ في قلتها وعدم جدواها، مما يبرهن على قدرة الثاعر التعبيرية، وحسن اختياره للألفاظ المعبِّرة المتتاسبة مع المقام. وفي البيت الرابع بطالعنا قوله:

ولكـن رأى مـا زاد عـن حاجـة ابنـهـ . مـن المـال أولـى بالـذي بـات طاويـا 
وموضع الثاهد قوله "بات طاويا" كناية عن الجوع وشدة الحاجة.

وهي كناية عن صفة قريبة، ومتداولة في منل هذا المقام ولذلك فهي لا تحتاج إلى تأمل في إدراكها، والمكنى به المذكور يلوح منه المكني عنه بوضوح وتبدو روعة هذه الكناية وجمالها وقوة تأثثرها أيضًا في تصوير المعنى الذهني المجرد "شدة الحاجة" بصورة مرئية تملأ نفوسنا إثفاقًا وأسى حين نشاهد صورة هذها هذها المحتاج الجائع الذي يجلس حزينًا مطويًا على نفسه وهذا تأكيد لثدة حاجته، وقد بدا ذلك جليًا من هذا الأسلوب الكنائي. ومما يتعاضد مع الكناية لتأكيد شدة الحاجة التعبير بالفعل "بات" الذي يدل على اليأس من الحصول على ما بيد

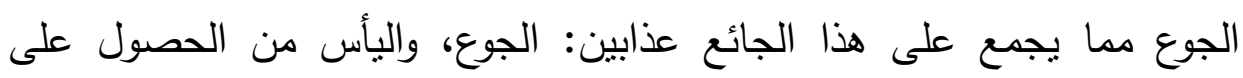
الطعام، فالجائع نهارًا يكون أمامه الوقت والفرصة للبحث عن طعام، أما وقد أدركه الليل فقد فات وقت البحث وأصبح من الملزم المبيت على الطوى، ولذلك تتاسب أن يعبر باسم الفاعل الدال على الثبوت والدوام "طاويا" الذي يرسم لنا صورة هذا

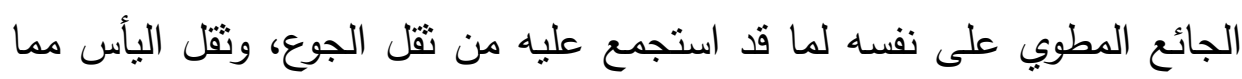
يحفز على الإشفاق عليه والأسى لله مما يدل على مقدرة الثاعر وتمكنه من اختيار ألفاظه المعبرة وامتزاجها مع التصوير للإحاطة بالمشهذ من كل جوانبه مما يجعل المتلقي لا يحتاج مزبدًا من البيان. وبالتأمل فيما سبق من كنايات نجد أن الأبيات التي احتوت هذه الكنايات وإن اعتمدت طريقة السرد - كما بينت - إلا أنها لم تستغن عن الكناية كأحد أهم الوسائل البيانية الكاشفة عن المعنى مما يظهر أهمية الكناية ودورها في إثبات المعاني حتى وإن كانت واضحة ظاهرة. كما أن هاتين الكنايتين قد دلتا على المعنى المقصود بطريقة رائعة، وأثتبت

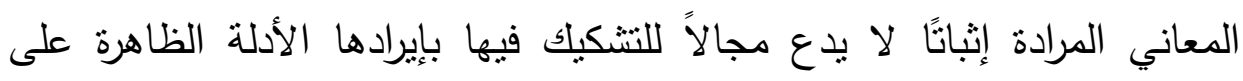


ثثبوتها، كما أنها متناغية مع مقام الحديث عن قناعة الصديق (ح) وثقته بما عند ربه، وحنوه على الضعفاء، وعدله وغير ذللك من المعاني التي لا يمكن للتعبير

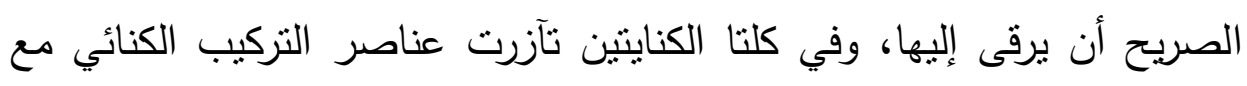
الكناية للقيام بأداء المعنى على خير وجه، مما يؤكد براعة الثاعر، وقوة شاعريته وحسن اختياره لألفاظه وكناياته.

\section{والله أعلم}




\section{الخاتمة}

وبعد، فقد عرضت لكنايات مختلفة وكثيرة في هذه القصيدة الرائعة، واستقصيت الكنايات فيها قدر الجهد، ولم أثرك شينًا منها عامدًا، وقد بدا لي بعد هذه المعايشة مع هذه الكنايات عدة نتائج أجملها فيما يلي:

1-ورد أسلوب الكناية في البكرية في حوالي (83) موضعًا، احتلت الكناية عن صفة النصيب الأكبر منها حيث وردت حوالي 76 مرة، وهذا شأنها بين أقسام الكناية في الثعر عامة، وجاءت الكناية عن موصوف حوالي 7 مرات، ولكن للأسف اختقت الكناية عن نسبة في البكرية مع مالها من رونق وجمال ولطف ومبالغة، ولا غرابة في ذلك، فالكناية عن نسبة بطبيعتها قليلة الدوران في الكلام عامة بجانب الكناية عن صفة والكناية عن موصوف. 2- تبين أيضًا أن المقام هو الذي استدعى أن تكثر الكناية عن صفة في القصيدة، لأنها تعداد لمآثز الصديق (ح) فناسبها الكناية عن صفة. 3- ظهر أيضًا أن الكناية في القصيدة لم تأت مفردة إلا في مواطن قليلة، وجاءت أكثرها كنايات مركبة.

4- بدا أيضًا أن معظم الكنايات التي وردت في القصيدة كنايات قريبة واضحة لا تحتاج عناءً في استخراجها وضوح مواقف الصديق (ح) وشهرتها. مما جعلها صورًا لطيفة تلامس النفس، وتتأى عن التكلف والغموض والاستكراه.

5-وضح أيضًا أن المواطن التي كانت الكناية فيها عن موصوف في القصيدة كانت الصفات فيها واضحة الدلالة على الموصوف فأرشدت عنه 
6- رأينا أيضًا أن كل الكنايات التي اشتملت عليها القصيدة جاءت متتاسقة مع المقام الذي تتحدث عنه، مما بدل على براعة الثاعر في اختيار كناياته.

7- لمسنا أيضًا أن المعنى الحقيقي مراد بجانب المعنى الكنائي في معظم مواطن ورود الكناية، وهذا مما يزيد في ثراء دلالة الكناية. 8- لاحظنا أيضًا أن الثاعر لم يكتق بكناية واحدة للتدليل على ما يذكره من مواقف وإنما يأتي بكنايتين أو أكثر للتنليل على معنى واحد تأكيدًا للتصوير وإمعانًا في إبراز المعنى، وذلك في معظم الكنايات التي أوردها. 9-شاهدنا أيضًا أنه في كثير من المواطن تتعانق الاستعارة أو التشبيه مع الكناية في تصوير المعنى المراد مما ساعد على رسم لوحات فنية متتاسقة ورائعة تأسر النفوس مما زاد أسلوب الكناية روعة وحلاوة، وهذا يكاد يشكل ظاهرة أسلوبية واضحة في معظم الكنايات التي وردت في القصيدة.

\section{والله من وراء القصد وهو حسبي ونعم الوكيل}




\section{قائمة المصادر والمراجع}

1- أفنان البيان، د/ الثحات أبو ستيت، مطبعة التركي، طنطا 1417هـ .1996

2- الإيضاح في علوم البلاغة، للخطيب القزويني.

3- البداية والنهاية، لإسماعيل بن كثير الدمشقي، خرج أحاديث الثيخ / محمد بيومي، أ// عبد الله المنشاوي، أ/ محمد رضوان مهنا، مكتبة الإيمان، المنصورة.

4- البيان في ضوء أساليب القرآن، د/ عبد الفتاح لاثين، دار الفكر العربي، ط2، 1420هـ - 2000م.

5- التصوير البياني، د/ محمد أبو موسى، مكتبة وهبة، دار التضامن للطباعة، ط2، 1400هـ - 1980م.

6- تطور الأدب الحديث في مصر ، د/ أحمد هيكل، دار نهضة مصر للطباعة والنشر

7- الخليفة الأول أبو بكر الصديق (ح) في مرآة الثاعر عبد الحليم المصري، د/ سالم عواد، بحث منشور بحولية كلية اللغة العربية بإيناى البارود، عدد بله

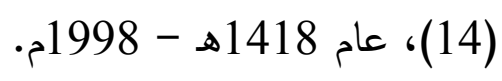

8 - دلائل الإعجاز ، ت/ شاكر، مكتبة الخانجي، القاهرة، طبعة المدني. 9- ديوان حافظ إبراهيم، ضبط وشرح وترتيب أحمد أمين، أحمد الزين، إبراهيم الإبياري، دار العودة، بيروت، لبنان.

10- ديوان الخيل في الجاهلية، جمع وشرح وتحقيق د/ عبد الله سرحان، مطبعة التركي، طنطا، ط1، 2005م. 
11- ديوان عبد الحليم المصري، طبع مطابع روزاليوسف، الهيئة العامة لقصور الثقافة.

12- السيرة النبوية، لابن هثام، ت / محمد بيومي، مكتبة الإيمان، المنصورة،

$$
\text { ط1، 1416هـ - 1995م. }
$$

13- شروح التلخيص، المطبعة الكبرى الأميرية، بولاق، ط1، 1323هـ. 14- الطراز المتضمن لأسرار البلاغة وعلوم حقائق الإعجاز، للعلوي، مطبعة المتقطف، مصر 1334هـ - 1914م.

15- فروق اللغات في التمييز بين مفاد الكلمات، لنور الدين بن نعمة الله الحسيني الموسوي الجزائري، ت د/ محمد رضوان الداية، ط1، 1424هـ .2003

16- الفروق اللغوية، لأبي هلا العسكري، ت/ أبي عمرو عماد ذكي البارون، المكتبة التوفيقية.

17- لسان العرب، لابن منظور ، دار صادر، بيروت. 18- المنل السائر، لابن الأثثر، تصحيح وتتقيح / محمد الصباغ، المطبعة العاشرة، القاهرة، 1282 - مه.

19- مدخل إلى علم البيان، د/ سلامة داود، بحث منشور بحولية كلية اللغة

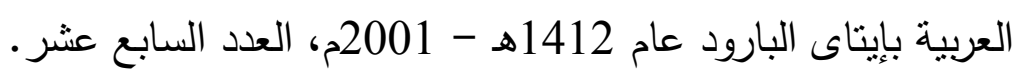
20- نقد الثعر، لقدامة بن جعفر، ت د/ محمد عبد المنعم خفاجي، مكتبة

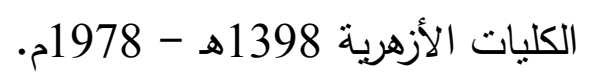
21- نهاية الإيجاز في دراية الإعجاز ، للرازي، ت / بكري شيخ أمين، دار العلم للماليين، ط1، 1985م. 1985. 
فهرس الموضو

\begin{tabular}{|c|c|}
\hline الصفحة & الموضــــــوع \\
\hline
\end{tabular}
المقدمة.

242 تمهيد - التعريف بالثاعر وقصيدته...

244 حول مفهوم الكناية. 248 نص القصيدة. الكناية في تصوير مناجاة الثاعر للصديق (ح) واعتذاره للرسول 257

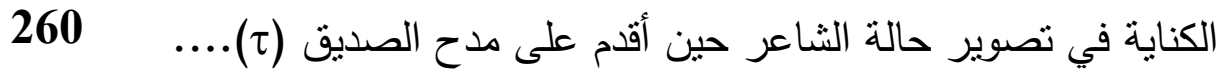
265 الكناية في تصوير أحقيته في الخلافة.

267

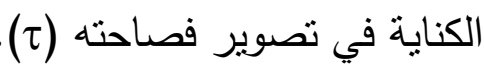

274 الكناية في تصوير موقفه من الإسراء.... 282 الكناية في تصوير موققه مع بلال بن رباح. 288 الكناية في تصوير موقفه في غزوة نبوك

294 الكناية في تصوير موقفه في الهجرة. 298 303 الكناية في تصوير موقفه من صلح الحديبية. 306 الكناية في تصوير موققه حين مرض الرسول (م).. 


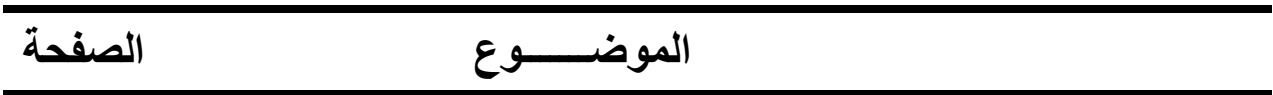

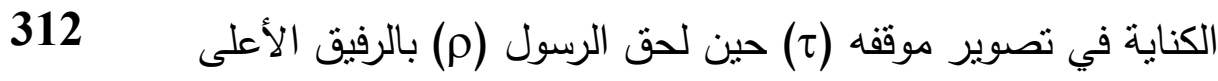

الكناية في موققه (ح) من إنفاذ جيش أسامة بن زبد لغزو الروم......

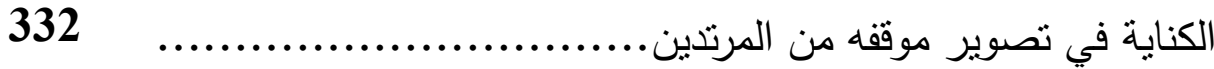

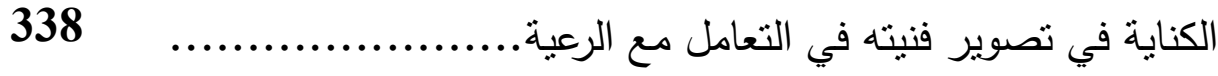

الكناية في تصوير ما فعله خالد بن الوليد في موقعة اليرموك تحت

341

قيادة الصديق (ح)

344

الكناية في تصوير تواضعه (ح)...

347

الكناية في تصوير الاقتداء به (ح)....

353

الكناية في تصوير أسبقيته إلى الخير .

357 الكناية في تصوير حاله بوم وفاته...

361 الخاتمة

363 قائمة المصادر والمراجع... فهرس الموضوعات. 